\title{
LA DEFENSA DE LA COMUNIDAD: SOBRE LAS FUNCIONES EMBLEMÁTICAS DE LAS MURALLAS PROTOHISTÓRICAS EN LA PENÍNSULA IBÉRICA
}

\author{
POR
}

\author{
LUIS BERROCAL RANGEL
}

\section{RESUMEN - ABSTRACT}

La arquitectura defensiva erigida por cualquier sociedad en su lugar de hábitat ha sido, y es, exponente máximo de las capacidades técnicas, ideológicas y socio-económicas de dicha comunidad. Por ello, los valores fundamentales materializados en las construcciones defensivas deben manifestar en gran parte singularidades y, a la par, elementos compartidos entre dichas comunidades. Este trabajo propone una vía inicial de análisis metodológico de tales valores aplicado a las comunidades indígenas de la Protohistoria Peninsular.

Architecture of a defensive nature built by any society to control and protect its settlements has been —and still is - the maximum expression of that community's technical, ideological and socio-economic capacities. Therefore, the fundamental values materialized in defensive structures should express to a high degree the singularities and, at the same time, shared elements among these communities. This work puts forward a new methodological approach for analysis of these values, using the Bronze and Iron Age communities in Iberica as a case study.

\section{PALABRAS CLAVE - KEY WORDS}

Poblamiento. Fortificaciones. Edad del Bronce. Edad del Hierro.

Settlement. Fortifications. Bronze Age. Iron Age.

\section{INTRODUCCIÓN: PLANTEAMIENTO INICIAL ${ }^{1}$}

Las murallas, manifestaciones de la diversidad comunitaria.

Las presentes páginas sirven para establecer una propuesta de investigación sobre los valores sociales de carácter emblemático detectable en la arquitectura defensiva indígena durante la Prehistoria tardía peninsular (Ss. VIII - I a./d. C.). Dicha propuesta parte de la consideración de la muralla como la construcción ordinaria de mayor envergadura acometida por una comunidad protohistórica en la Península Ibérica. En tal sentido, la aplicación de los conceptos técnicos y estéticos tenidos en cuenta durante su edificación deben haber respon-

1 Este trabajo se ha realizado dentro del Proyecto «Las fortificaciones prerromanas de la Península Ibérica.» (BHA2003-02199). Agradecemos las sugerencias e ideas recibidas de los Dres. Lucas Pellicer ( $\dagger$ ), Almagro-Gorbea, Blasco Bosqued y, especialmente, Pierre Moret. 
dido a criterios aceptados y compartidos por dicha comunidad, asumiendo, con ello, valores simbólicos de primer orden.

Del planteamiento de esta hipótesis deducimos que el análisis de las técnicas y de los elementos estructurales usados en estas construcciones, y su cotejo con las recurrencias documentadas en diferentes contextos del poblamiento peninsular, permitiría definir diferentes modelos teóricos en los sistemas defensivos, «modelos» que responderían a las principales características emblemáticas compartidas entre las comunidades de dichos contextos culturales y territoriales. En consecuencia, serían capaces de reflejar las diversas entidades e identidades comunitarias de carácter comarcal que integraban las sociedades protohistóricas peninsulares, confirmando, descartando o matizando, desde una base metodológica más objetiva y coherente con estos restos materiales, las tradicionales demarcaciones étnicas prerromanas transmitidas por los escritores greco-latinos.

Todo este desarrollo metodológico se aborda aquí con un propósito prospectivo, un intento por comprobar la viabilidad del modelo. Por ello se aplica de forma selectiva, primero, sobre una serie de diez elementos estructurales considerados por sus connotaciones étnicas o culturales y, posteriormente, se procede a su cotejo sobre el poblamiento protohistórico de cinco comarcas peninsulares (1. Alto Guadalquivir - 2. Bajo Ebro - 3. Serranías orientales de la Meseta - 4. Valle Medio del Duero - 5. Cantábrico occidental). De estos ensayos, el resultado final permite asegurar unas conclusiones iniciales que divergen del panorama étnico tradicional en algunos de los casos (1), confirman otros (2 y 4) o reflejan panoramas anteriores ( 3 y 5), incidiendo en la naturaleza mutable y compleja de las comunidades peninsulares frente a la visión estática transmitida en los testimonios greco-latinos.

\section{Postulados DEL MODELO TEÓRICO}

II.1. Las murallas, los primeros recursos complejos de un poblamiento estable

Nuestro planteamiento inicial parte de la consideración del surgimiento de los poblados fortificados en la Prehistoria europea como la primera evidencia material del proceso que gestará la complejidad del poblamiento contemporáneo, representado por la ciudad aunque, para algunos investigadores, pudiera haber conducido también a resultados paralelos «nourbanos» (Buchsenschutz 2001). Su importancia se ha justificado, normalmente, con criterios sobre capacidades técnicas y económicas, sobre tácticas y estrategias bélicas que olvidan, a menudo, otros valores y funciones tan importantes como los anteriores. Quizá por ello P. Leveque, en las conclusiones de un conocido coloquio sobre fortificaciones griegas, propuso abordar el fenómeno del poblamiento fortificado desde enfoques antropológicos, analizando la repercusión social e ideológica que supuso la construcción y utilización de las murallas en la Antigüedad (Leveque, 1986: 378).

Esta óptica, novedosa hace dos décadas, se ha convertido en la actualidad en uno de los ejes prioritarios de la investigación, asumiendo la tradición historiográfica avanzada por los prehistoriadores al abordar el tema integrándolo en los estudios de territorialidad y poblamiento (p.e. Collis 1989; Guichard et alii 2000; Fichtl 2000). Claro que tales estudios concedían al fenómeno de fortificarse la importancia subsidiaria que tiene en el poblamiento y, quizá por ello, pocas veces fue objeto de un análisis específico, olvidándose de las posibles dependencias que, en ciertos momentos y contextos, el hábitat doméstico demuestra respecto a las construcciones que lo defienden (Vide infra.....).

Más escaso ha sido el tratamiento del hábitat fortificado desde enfoques sociales, donde suele ser citado sin referencias específicas, más allá de algunos ejemplos excepcionales como el conocido oppidum de La Heuneburg. Es fácil que, entre las entelequias sociales utili- 
LA DEFENSA DE LA COMUNIDAD

Las funciones emblemáticas de las murallas protohistóricas peninsulares

\section{Premisa}

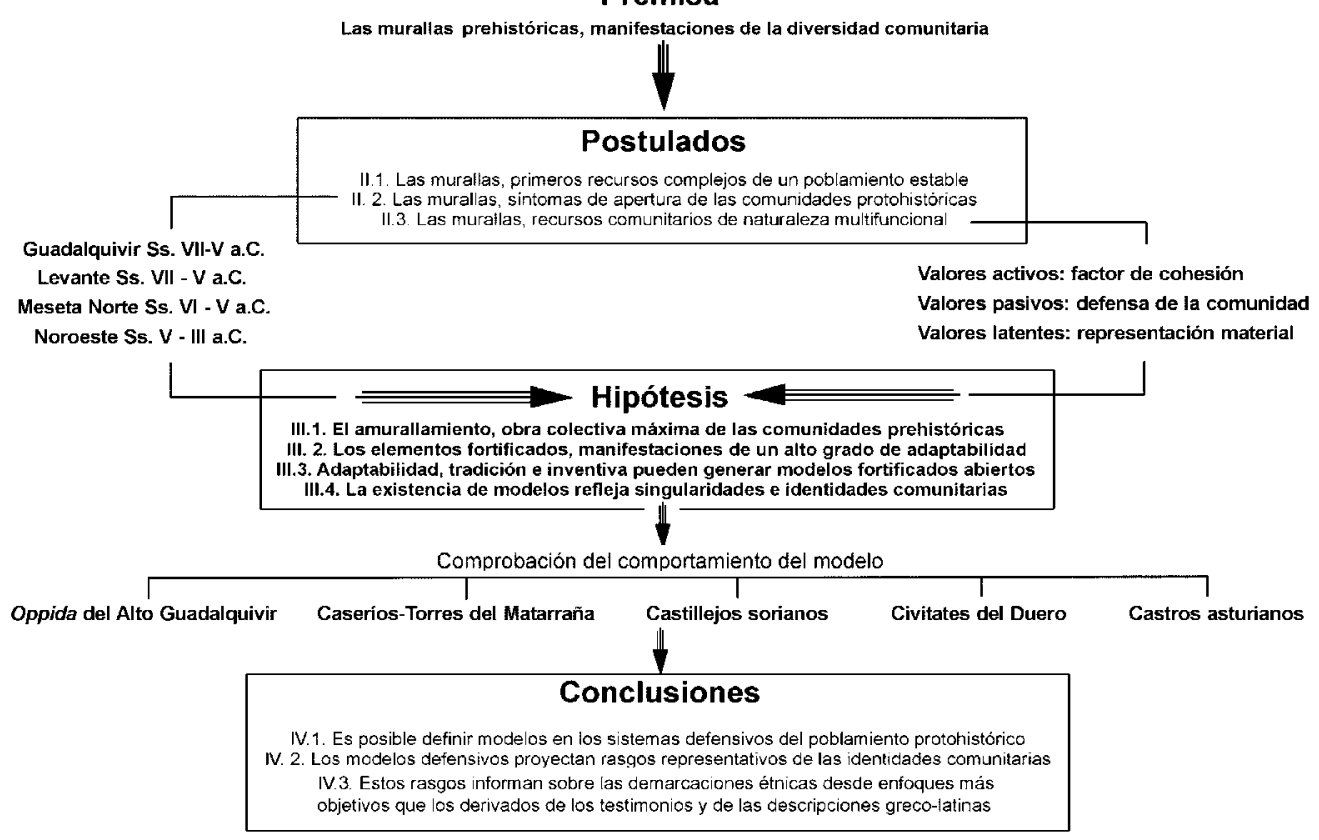

Lámina 1.1. Síntesis del modelo teórico aplicado.



Lámina 1.2. Puerta a tenaza del tercer recinto de Los Millares, una construcción tan compleja en su planimetría como monumental, especialmente si se considera el foso que se abría frente a ella. 
zadas por los prehistoriadores y arqueólogos, las poblaciones pre-estatales se analicen en relación con sus costumbres funerarias, religiosas o comerciales, pero se dedica poco espacio al estudio de las defensas de dichas poblaciones (así se constata, por ejemplo, en libros clásicos como Farms, Villages, and Cities. Commerce and Urban Origins in Late Prehistoric Europe de Peter Wells, 1984, o en la reciente síntesis sobre la investigación protohistórica del Mediodía peninsular escrita por el prof. Escacena: 2000).

$\mathrm{Y}$, sin embargo, en las estructuras sociales generalmente aceptadas para definir el desarrollo de las sociedades prehistóricas, el poblamiento fortificado es considerado como una característica inherente a las categorías «estratificadas» definidas por Fried (1967: 722) y, concretamente, a la estructuración «dumeziliana» de unas comunidades regidas por las elites militarizadas que conformaron en Europa en diversos momentos y circunstancias durante el último milenio antes de Cristo, la llamada Demokratie Militärische de F. Engels (1884: El origen de la familia.....; Cunliffe 1982 y 1988: 88; Almagro-Gorbea 1994: 46 y 1996: 121 ss.; Guilaine y Zammit 2002: 222 ss.). Tal es así que la ausencia generalizada de fortificaciones en poblados estables sólo se comprende bien en las primeras fases y tentativas de la «sedentarización» neolítica o, por el contrario, en estructuras estatales desarrolladas: «il ne saurait y avoir de fortification sans l'existence d'une structure politique forte.» (Leriche 1992: 9).

En suma, nuestra premisa define la fortificación del poblamiento como reflejo de la consolidación y del éxito de la ocupación estable de un territorio concreto, sin duda porque representa la mayor manifestación del poder y del prestigio de sus habitantes dentro de una estructura jerarquizada incipiente, aunque pueda responder también a razones más primarias y simples como la respuesta a una desigualdad social continua (Brun, 1995: 18; Collis 1993: 232; Harding 2003: 287 ss.).

Para justificar tal planteamiento es necesario reafirmar, en primer término, el valor de la fortificación como garante de la estabilidad del hábitat. No en vano, Fernando Romero eligió el afortunado título de «El afianzamiento de la sedentarización y la explotación intensiva del Medio» para la síntesis de Hierro Antiguo en la Meseta Norte publicada en 1985, un título explícito para el período en el que en este territorio se consolida el proceso de fortificación de su poblamiento. Incluso antes de proceder a defenderlos con estructuras algo más complejas que fosos y empalizadas, tanto en la Península como en otras regiones de Europa, ya se había experimentado con éxito en otros recursos paralelos como la arquitectura funeraria y ritual representada por los megalitos (Renfrew 1983; Tilley 1994; Briard 1995...). Y, así, ambas manifestaciones son consideradas como expresiones materiales máximas del dominio ejercido sobre el territorio habitado.

En segundo término, y continuando con esta analogía conceptual, las construcciones megalíticas y murallas reflejan capacidades extraordinarias en la inversión de los recursos de cada comunidad, especialmente porque comparten una naturaleza monumental como rasgo intrínseco: «In human societies, the control of energy constitutes the most fundamental and universally recognized measure of political power. The most basic way in which power can be symbolically reinforced is through the conspicuous consumption of energy. Monumental architecture, as a highly visible and enduring form of such consumption, plays as important role in shaping the political and economic behaviour of human beings.» (Trigger 1990: 128).

Por ello es evidente que un rasgo de «monumentalidad» constructiva, dentro de los parámetros comparativos al uso, es consustancial a las primeras fortificaciones complejas de la Prehistoria europea y, en tal sentido, se han destacado sus valores intramuros como referente vial y extramuros como punto focal del paisaje comunitario (Lám.: 1 - Chalandriani, Lerna, Los Millares, Phylakopi, Hattusa, Micenas: Adam 1982: 9-11; Darcque 1992: 12-19). Así, ya en la antigua Grecia como en Roma, la muralla servía como elemento definidor del «microcosmos ordenado» que contenía y que era, en términos locales, la propia comunidad y, en términos universales, el propio sentido de pertenencia a la Civilización (Garlan 1974: 177, y 
1992: 36; Ryckwert 1985; Bendala 2003: 20-24). Un planteamiento cercano es utilizado para los castros y «hill-forts» atlánticos de la Edad del Hierro, considerados «puntos de atracción visual en el paisaje y, como tales, identificadores de un grupo social frente a otro. Sólo los castros más modernos pierden —y nunca del todo— esta característica» (Fernández-Posse 1998: 209). Esta concepción de la muralla como baliza del paisaje castreño, mantenida por diferentes prehistoriadores (p.e. Parceo 2000; Almagro-Gorbea 1994; Carballo 1993), tiene su correspondencia interior en su consideración como referente vial de la Arquitectura doméstica, tal como M. D. Fernández-Posse, J. Sánchez-Palencia y A. Orejas argumentan sobre registros tan afortunados como los procedentes de las excavaciones del castro leonés de Borrenes. Abandonado súbitamente mientras que se culminaba la excavación / construcción del foso y de la cerca amurallada, Borrenes muestra cómo su población había procedido primero a la realización de tales elementos para, a continuación, acomodar el hábitat interior al trazado de la muralla (Sánchez-Palencia et alii, 1996; Fernández-Posse 1998: 220).

\section{II.2. La fortificación del poblamiento, síntoma de la apertura de las comunidades}

La siguiente premisa del modelo propone que el fenómeno del amurallamiento generalizado responde a un grado de complejidad social concreto, definido por la combinación coetánea de ciertos elementos técnicos y económicos de naturaleza aperturista (cuando no sociales), independientemente del proceso evolutivo en el que se inserten. Así se pueden reconocer sistemas fortificados con un desarrollo tan complejo como los poblados amurallados calcolíticos, sin «aparente» continuidad durante la Edad del Bronce pero con contextos socioeconómicos mucho más cercanos a los constatados un milenio después, entre las «sociedades estratificadas» del Hierro (Chapman 1991; Nocete 1994 y 2000)2.

Para defender tal premisa hemos analizado, en primera instancia, los factores que concurren en las poblaciones que generalizan la costumbre de amurallar sus poblados. El carácter predictivo de este trabajo impuso la elección de cuatro casos de estudio, aplicados a territorios y contextos arqueológicamente muy significativos: el Alto Guadalquivir, el Levante valenciano, la Meseta Norte y el Noroeste peninsular. En todos ellos se comprueba que el fenómeno acontece tras contextos de especial carácter aperturista, frente a la imagen primaria de cerramiento que representa una muralla. Por ello, en segunda instancia, se optó por analizar la dispersión de ocho elementos defensivos de aparente procedencia extrapeninsular, y comparar sus comportamientos frente a otros dos peninsulares, a fin de conocer y comprobar la medida y la forma de sus desarrollos en relación con la aloctonía / autoctonía.

\subsubsection{Los factores de la generalización del poblamiento amurallado:}

Las razones utilizadas para tales distancias sociales y temporales deben localizarse en los testimonios de lo que denominamos «Arqueología del intercambio»: depósitos de bienes de prestigio, materiales alóctonos, y poblados relacionados, como vestigios de redes de relaciones

2 La «discontinuidad» entre las murallas calcolíticas y las de la Edad del Hierro se detecta con claridad en el grado de complejidad y en la extensión del fenómeno, pero no su inexistencia pues cada vez es más patente que ciertas comunidades peninsulares, literalmente sobre algunos de los grandes centros territoriales de las campiñas del Guadalquivir y del Sureste al menos, mantienen un desarrollo fortificado que, si bien no puede equipararse con sus precedentes, sí conserva gran parte de sus técnicas y procedimientos más sencillos (como ha planteado con no pocos argumentos y datos P. Moret, 1996: 184-187, y se refrenda en paradigmas de la proyección de la complejidad Calcolítica sobre las comunidades del Bronce, como Los Alcores-Albalate, Peñalosa, El Cerro de la Virgen, o Fuente Álamo, en la línea de las transformaciones definidas por F. Nocete 2001: 137-148). La continuidad en el sentido técnico es, por tanto, mayor de lo que pudiera presumirse a primera vista. 
estables donde la presencia de enclaves centrales fortificados se documenta en cualquier territorio europeo que sea investigado, como afirma A. F. Harding (2003: 292; Krausse y Nakoinz 2000; Podborsky 1970, etc.). Además estas relaciones inciden en la capacidad y en la naturaleza de este intercambio, demostrando la movilidad de ideas y técnicas independientemente del contexto cultural, hasta el extremo de presentar ejemplos tan significativos como el oppidum polaco de Biskupin, que ha sido es considerado, no sin claras dudas, como resultado de ideas urbanísticas mediterráneas en los lejanos territorios del Báltico (Bouloumié 1990). No menos paradigmático es el caso de La Heuneburg IV, más cercano y nítido, y menos transformado desde sus modelos meridionales como consecuencia de su corto período de uso y rápido abandono, pese a que su muralla de adobes y madera se demostraría más resistente a la intemperie que cualquiera de las que le seguirían (Kimmig 1983; Cunliffe 1988: 29).

Por tanto consideramos que el desarrollo de los «intercambios extensos y estables de bienes de prestigio» y su relación con las jefaturas guerreras en entidades pre-estatales descentralizadas conforman los factores generadores de la complejidad, en primera instancia, y de la extensión mayoritaria, en segunda, del poblamiento fortificado, en línea con lo defendido por prehistoriadores como K. Kristiansen (2001: 136, 289 y 328). Por ello asumimos la postura más matizada de P. Wells que refuerza la hipótesis de partida, el valor simbólico de este proceso frente a las ventajas meramente militares, aunque todos sean conceptos íntimamente implicados (1984: 25; Johnson y Earle 2003: 312).

Como apoyo a estas afirmaciones es posible analizar la presencia y relación del intercambio estable a larga distancia de bienes de prestigio con amortizaciones en depósitos, con la generalización del hábitat fortificado y con el desarrollo de una sociedad estratificada «militarizada» a lo largo de las líneas generales del poblamiento europeo durante el último Milenio antes de la Era Cristiana. Así se puede comprobar cómo a un hábitat encastillado y caracterizado por el hallazgo de depósitos «votivos» de objetos exóticos del Bronce Final, le sucede un Hallstatt C definido por el abandono de muchos de estos poblados y por un desarrollo desconocido de la inversión funeraria, hasta ser acorde con lo esperado de una sociedad denominada «principesca» (Collis 1989: 119-120; Wells 1984: 25). A partir de mediados del siglo VI, entre los periodos del Hallstatt $\mathrm{D}$ y La Tène $\mathrm{A}$, se rompe progresivamente con esta tendencia y se reocupan los poblados abandonados en la fase anterior, dotándolos de sistemas poliorcéticos complejos tomados de griegos y etruscos en medio de un proceso de creciente «militarización» social (Wells 1984: 102-118; Brun 2001: 39; Collis 1989: 126-132; Cunliffe 1988: 36-37). Por último, tras un nuevo receso de las pautas fortificadoras durante el período de La Tène $\mathrm{B}$, las poblaciones centroeuropeas volverán a encastillarse durante el siglo II a.C. en oppida como Bibracte, Pandours, Essalois o Joeuvre, caracterizados por los importantes depósitos de ánforas Dressel que testimonian el relanzamiento de las vías comerciales (Cunliffe 1988: 87-97; Buchsenschutz et alii 1999; Fichtl 2000: 37, 68 y 110ss.; Guichard et alii 2000).

Es cierto que conforme avanzaba el I milenio a.n.e., las amortizaciones rituales en depósitos parecen descender en número y entidad frente a la creciente inversión funeraria, y que todos estos procesos coinciden con un aumento de la movilidad y la inestabilidad social, culminado con los acontecimientos producidos por la expansión romana. Pero tampoco puede olvidarse que las murallas sirvieron para manifestar el poder de la comunidad que albergaban, en relación con la mano de obra y de la organización técnica necesaria ${ }^{3}$.

Para comprobar en qué medida y manera se cumplen estos planteamientos en la Península hemos decidido analizar, a modo de muestreo, el proceso de gestación de la complejidad y

3 La taille et l'indéniable qualité esthétique de ces remparts, surtout de leurs portes monumentales, constituaient une manifestation de prestige et de pouvoir: ce important ouvrage témoignait de la capacité de mobilisation et d'organisations d'une main-d'oeuvre nombreuse qui, symétriquement, reforcait dans cette réalisation collective son sentiment d'appartenance à l'unité sociale et politique garantissait la sécurité et la régularité des échanges.» (Brun 2001: 39). 
generalización del poblamiento fortificado en los cuatro ámbitos arqueológicos citados, dada la marcada singularidad cultural de todos ellos:

1. El Alto Guadalquivir, con las campiñas jienenses, cordobesas y granadinas, y con sus relaciones con el Occidente bético.

2. El Levante valenciano, especialmente referido a los territorios bañados por los ríos Turia y Júcar, y sus relaciones con el Bajo Ebro.

3. La Meseta Norte, en las cuencas Media del Duero y la del Pisuerga.

4. El Noroeste, en el sentido lato del término, incluyendo tierras portuguesas, gallegas, asturianas y limítrofes de León y Zamora.

1. El Alto Guadalquivir y sus tierras aledañas forman un territorio con destacada personalidad arqueológica, al menos, durante toda la Prehistoria Reciente (Chapman 1991; Nocete 2003). Por ello no es de extrañar que el origen de su poblamiento fortificado se remonte a los momentos iniciales del fenómeno en Europa, a contextos calcolíticos del III Milenio cada vez más extensos y mejor conocidos, y de los que perdurarán, un tanto de forma aletargada, algunos de sus avances poliorcéticos básicos (Martínez Peñarroya 2000). Si bien no hay nada en el II Milenio que se aproxime a Marroquíes Bajos, por no citar Los Millares, está comprobado el uso del adobe, de los paramentos múltiples y de las torres huecas de planta subrectangular achaflanada en poblados de la plenitud de la Edad del Bronce como el Cerro de la Viña, Fuente Álamo y la Cuesta del Negro de Purullena (Moret 1996: 177 y 184-187; Contreras, 1993; Schubart et alii 1986; etc.). Pero, como han destacado diferentes especialistas, no será hasta los inicios del I Milenio cuando, como en el resto del Valle Bético, se asista a un resurgimiento del proceso de fortificación del poblamiento, especialmente evidente a lo largo de las vías de contacto utilizadas en las primeras relaciones estables con las Civilizaciones mediterráneas.

Estas primeras murallas se emplazan desde el Golfo de Cádiz hasta el interior andaluz a fines del siglo VIII a. C. (Niebla, Tejada la Vieja, Setefilla, Ategua, Aznalcóllar, Torreparedones, Puente Tablas....: Escacena y Fernández Troncoso 2002; Ruiz y Molinos 1993: 199; Pérez Macías y Bedia 1995, García Sanz 1987; Aubet et alii 1983; Molina 1978; Moreno López 2002; Fernández Castro y Cunliffe 2002, etc.). Y, aunque mal conocido por ahora dado que la información procede básicamente de sondeos, el modelo fortificado de tales oppida denuncia con sus bases ataludadas de mampostería y sus alzados de adobe revocado la influencia o la difusión de las «murallas ciudadanas» fenicias (Ruiz Mata, Niveau y Vallejo 1998: 72; Torres 2002: 268-269; Escacena y Fernández Troncoso 2002: 120-122 frente a Escacena 2000: 60 y Díes Cusí 2001: 96). Sin embargo esta presencia oriental se diluye entre los componentes indígenas cuando, a partir del siglo VI a. C., se generaliza el poblamiento fortificado como recurso material e ideológico en medio del crecimiento de los oppida posttartésicos (Puente Tablas, Atalayuelas, Torreparedones, Tejada 2....: Ruiz y Molinos 1993: 199-202; Ruiz Rodríguez 1992: 107; Cunliffe y Fernández-Castro 2002; Moreno 2002; Fernández-Jurado 1987; Keay 2002, etc.).

Así la generalización del poblamiento fortificado en el Alto Guadalquivir, ya complejo y consolidado, se constatará a partir de este siglo VI, inserto en las bases iniciales de la Cultura ibero-turdetana, y será consecuencia, por una parte, del éxito de un sistema estable de relaciones comerciales y de intercambio con la costa. Y, por otra, emergerá de una estructuración social donde los valores guerreros de las elites dominantes se impondrán sobre la concepción monárquica y sacra de los períodos anteriores (como se colige de un desarrollo funerario con numerosas armas en el ajuar o con representaciones como las del Cerrillo Blanco de Porcuna: Quesada Sanz 2002: 37- 42; Almagro-Gorbea 1996: 121 ss.; Negueruela 
1990). «El armamento pasa por ser, en el siglo VI a.n.e., otro elemento definidor del grupo social dominante y como tal debe ser entendido» (Ruiz y Molinos 1993: 214). Con todo ello, a partir del siglo VI a. C., en la Alta Andalucía se desarrolla una dinámica que justifica el triple planteamiento de esta premisa: «intercambio estable a larga distancia de bienes de prestigio, sociedades guerreras y generalización del hábitat fortificado (complejo)» redundan en la presencia relacionada de tales elementos.

2. Frente al desarrollo anterior, el Levante (Turia - Júcar) se caracteriza por la falta de precedentes o de referentes exteriores que justifiquen el desarrollo poliorcético que demostrarán las posteriores poblaciones ibéricas. Porque, en poco más de la centena de años del siglo VII a.C., se atiende a la desaparición de hábitats aislados del Bronce, que no demuestran otra capacidad defensiva que sus emplazamientos inaccesibles y algún muro exterior de contención (Bernabeu 1989 et alii), y al surgimiento de un poblamiento jerarquizado y complejo, con pequeños poblados de «calle central» atalayados como Puntals, Cova Foradada o Castellar de Chulilla, todos ellos dispersos en torno a grandes poblados fortificados como Los Villares - Kelin, o San Miguel de Liria - Edeta, La Serreta, etc. Bonet y Mata 2001: 181; Bernabeu et alii 1987). El mismo Tossal Redó, Muntanya Assolada, Caramoro I y, quizá, Puntals dels Llops por citar algunos de los poblados del Bronce que continuarán ocupados, manifiestan, cuando no una transformación urbanística total, la construcción de unas defensas que en no pocos casos aprovechan los muros anteriores integrándolos en un sistema dominado por una o varias grandes torres. El hecho, que sucede en el tiempo a la generalización de las cerámicas fenicias durante el citado siglo VII, se incardina con la importancia del comercio costero en el Litoral valenciano y el Bajo Ebro, y con la organización jerarquizada del hábitat, interpretada incluso desde ópticas fronterizas y militarizadas (Díes Cusí 1991; Gracia et alii 1999; Moret y Benavente 2000: 335; Bonet y Mata 2001: 178, y 2002: 213; y, con críticas, Moret 1996: 155 y Grau, quien baja esta complejidad hasta el siglo III a. C. 2002: 204). De nuevo la asociación «intercambio estable a larga distancia- sociedades guerreras - generalización del hábitat fortificado» se cumple a partir del siglo VI a.C.

3. En la Meseta Norte, especialmente sobre los valles del Pisuerga, Cega, Sequillo, Esla, y otros subsidiarios de la Cuenca Media del Duero, se presentan los primeros poblados fortificados en contextos del Bronce Final, con fosos, parapetos y emplazamientos cerrados sobre terrazas fluviales, en estos casos fechados entre los siglos IX y VIII a. C. En ellos, el poblamiento muestra una clara relación con las posibles vías interiores del intercambio, señalizadas en este caso por la aparición de numerosos depósitos de producciones metálicas como Valdevimbre, en la transición Cogotas I - Soto (Celis 2002: 98-99; Delibes y Fernández Manzano 2000: 218, etc.). Así se considera la ocupación de poblados de cierta extensión como Las Labradas de Arrabalde y Ardón..... aunque los elementos fortificados complejos no harán su aparición al menos hasta el siglo VI con las primeras evidencias de murallas de tierra y madera asociadas a fosos, que acompañan al desarrollo de la Cultura de Soto. Coincide, entonces, con un incremento desconocido de las ya tradicionales relaciones exteriores, hasta el punto de vincularse gran parte de la complejidad constructiva y técnica con la existencia de contactos estables y regulares con los extrarradios tartésicos del Suroeste peninsular (Manganeses de la Polvorosa, Valencia de Don Juan, Soto de Medinilla, Valoria la Buena, Villacelama.....: Celis 2002: 103-108; Blasco 2001: 204; Delibes y Fernández Manzano 2000: 112; Delibes et alii, 1999; San Miguel 1993; Blasco y Alonso 1986-1987, etc.).

En este caso, el ejemplo del poblamiento protohistórico del Valle medio del Duero marca la relación entre el intercambio estable a larga distancia de bienes de prestigio y la generalización del hábitat fortificado a partir del siglo VI a.C. en una sociedad con un fuerte componente campesino, agrícola y ganadero, donde los elementos relacionados con la guerra tarda- 
rán algo más en hacer acto de presencia — siglo $\mathrm{V}$ a.C. como muy temprano, acorde a un grado de jerarquización relativamente bajo (Sacristán et alii 1995: 366)—, constituyéndose como en el caso del Guadalquivir, en símbolos del grupo social dominante (Sanz Mínguez 2002: 91 ss.).

4. Resta, por último, el ámbito del Noroeste peninsular. Aunque recientemente se van conociendo fortificaciones anteriores con emplazamientos cada vez más septentrionales- ${ }^{4}$, el poblamiento fortificado no entra en una trayectoria continua hasta los últimos siglos de la Edad del Bronce. Entonces, estas primeras murallas se interpretan como un recurso para la protección de los excedentes metalúrgicos habidos en los contextos aperturistas contemporáneos (Martins y Jorge 1991-1992: 356). Su progresiva expansión, hasta la exclusividad, está cada día mejor documentada gracias a las dataciones radiocarbónicas aportadas por las fases iniciales de numerosos castros que, en no pocos casos, se presentan con extensiones y envergaduras notables, y con una evidente relación con los circuitos costeros de los que deriva una importante actividad metalúrgica y una considerable inversión ritual asociada (Nossa Senhora da Guía, Torroso, Penalba, Chao Samartín, pero también O Neixon Pequeño, Taramundi....Arias 2002: 134; Villa 2002: 162-166; Xusto 2000; Pereira 1999; Silva 1986).

Tales relaciones han servido para plantear distintas teorías que apoyan un inicio temprano de la complejidad social inherente al poblamiento castreño, aunque su desarrollo se hace especialmente patente desde el V a.C. gracias a la proliferación de cerámicas fenicias y griegas en emplazamientos costeros y a una relativa generalización del aparejo pétreo (Correia 2001: 217-218 y 221; Martins 1990; Carballo 1993; De la Peña 1992: 382). Por ello, algunos autores han planteado la configuración de un poblamiento jerarquizado que culmina en una cultura de oppida a partir de tal fecha (Martins 1990; Carballo 1993), aunque ello implica asumir ciertas incoherencias cronológicas (pues las ocupaciones en extensión de estos poblados son mucho más tardías, como la orfebrería y, especialmente, la escultura monumental que les acompaña). Otros planteamientos más moderados, como los defendidos por C. Parcero sobre una sociedad campesina y militarizada, permiten compaginar mejor los vestigios y las secuencias cronológicas (1995 y 2000: 92). Incluso en los territorios interiores, donde las vías de intercambio debieron pasar de lejos, el poblamiento fortificado pudo gestarse en las estructuras autárquicas denominadas «sociedades agrario-segmentarias de aldea» por M. D. Fernández-Posse, que no se transformarán hasta el impacto romano (1998: 209-210; Sastre 2002: 228-231 y 2000). En tal sentido, y aunque sea difícil su conjunción con datas y datos generales, esta interpretación encuentra el apoyo del cuarto elemento de nuestra libre asociación, el tardío desarrollo de una sociedad estratificada militarizada reconocida a duras penas en las espectaculares estatuas de guerreros galaicos (Silva 2003; Schattner 2003.....) y en la joyería de torques, que pudiera retrasarlo hasta unos siglos antes de la presencia romana en estas tierras (Silva 1996: 144-145). Aún así debe tenerse en cuenta, al valorar esta ausencia, la parca naturaleza material de las costumbres funerarias (Bettencourt 2002) y la presencia de otros testimonios que inciden en la beligerancia de estas poblaciones (p.e. en los grabados de guerreros y jinetes armados de la Foz del Coa: Abreu et alii 2000).

\subsubsection{Del aperturismo de la generalización: la aloctonía de los elementos defensivos}

Por tanto, si en estos ejemplos se confirma la apuesta por el poblamiento fortificado a partir de los momentos aperturistas de los siglos VII y VI a. C. entre las sociedades jerarqui-

\footnotetext{
4 Como se pudo comprobar en la mesa-redonda Recintos murados da Pré-história recente: técnicas constructivas e organizaçâo do espaço (Jorge, ed. 2003).
} 
zadas o «estratificadas», es necesario preguntarse a continuación por la naturaleza y la procedencia de dicho recurso constructivo, en el sentido que el contexto de apertura implica, es decir, en la medida en que las técnicas y tácticas empleadas en la fortificación se expanden, o no, por las vías de intercambio reconocidas para tales momentos.

Tal razonamiento redunda en la concepción difusionista tradicional aplicada a los avances poliorcéticos peninsulares, sea cual fuere el momento y el territorio tratado. Así, desde el otrora llamado «horizonte colonial» Calcolítico y la emulación de Chalandriani ${ }^{5}$ al reconocimiento de los «sistemas greco-ibéricos» de la poliorcética y el caso de las torres de Banyoles (Pallarés, Gracia y Munilla 1986, etc.), se ha considerado siempre el predominio de los factores exteriores frente a un escaso grado de interacción e inventiva indígena. Solo en tiempos recientes se han valorado las tradiciones e iniciativas locales, a veces también en posiciones un tanto radicalizadas (p.e.: Romeo 2002).

Para el análisis historiográfico de estas corrientes difusionistas, y del grado y la manera de cómo afectaron a los diferentes desarrollos poliorcéticos peninsulares, hemos seleccionado ocho elementos defensivos que nos parecen significativos, por cuanto sus supuestos orígenes fueron interpretados como préstamos procedentes de dos grandes ámbitos culturales extrapeninsulares: la Europa centroeuropea (las murallas de adobes y madera, las de piedra y madera, los paramentos múltiples y los campos de piedras hincadas impropiamente llamados «chevaux-de-frise») y las Civilizaciones mediterráneas, ya fenicias, púnicas o helénicas (murallas de cajones y de casamatas, aparejo ciclópeo, torres cuadrangulares, etc.).

1. Las murallas de adobe y madera de tipo «Soto» conformaron uno de los tópicos que, mediado el siglo XX, se adscribieron a la celticidad peninsular (Fig.: 1.1). Cierto parentesco constructivo, que no planimétrico, con yacimientos europeos como La Heuneburg (Palol, 1964; Palol y Wattemberg 1974: 181-195) y Agde (Treziny 1986: 197) obvió la singularidad de estos en sus ámbitos centroeuropeos, donde representan verdaderos «caprichos» mediterráneos. Por otra parte la utilización de un material tan abundante y de tratamiento tan sencillo como el barro cocido al sol puede considerarse como un recurso técnico de aplicación natural, especialmente en las comarcas ricas en suelos arcillosos. Por ello, no debe extrañar que, como ha documentado con detalle P. Moret, el uso de adobes tenga una vieja tradición en la Península Ibérica que remonta su uso hasta el Calcolítico, tanto en la arquitectura defensiva como la doméstica, siendo su perduración puntual pero continuada a lo largo de las Edades del Bronce y, como no, incrementándose durante el Orientalizante peninsular (Los Millares, Marroquíes Bajos, Zambujal, Orce, Los Saladares, La Encantada, Medellín......Moret 1996: 189 y 194 ss.; Zafra et alii 1999).

Por tanto, no puede extrañar que las investigaciones posteriores hayan destacado la personalidad del uso del adobe entre las poblaciones Soto-Vacceas, con una naturaleza concreta que se comprende desde la propia experimentación en una tierra abundante en arcillas y escasa en piedras de grano duro (Polvorosa de Manganeses, Villacelama, Pintia, Sanz Mínguez 2003; Celis 2002-a: 107; Misiego et alii 1998: 28-29; Moret 1996: 195). Esta personalidad constructiva aparece conformada con una complejidad notable que la asimila, en parte, al uso tradicional del adobe, en parte a la tierra prensada y, en una similitud equívoca, al tapial. Así se ha podido comprobar la construcción de paredes de doble paramento realizado con tongadas de adobes, o de tierra prensada en revestimientos de madera - p.e. en Pintia —, que a su vez servían para albergar un relleno de tierra prensada y vigas de madera, éstas como los soportes principales del levantamiento (Centeno et alii, 2003: 75-76; Gómez y San Mínguez 1993). Estas aplicaciones, bien conocidas en la Arquitectura doméstica, fueron usadas para la construcción de sus murallas demostrando una fuerte personalidad cultural, claramente relacionada con el entorno del Duero Medio desde finales de la Edad del Bronce en sus poblados más estratégicos (San Mínguez 1992: 29).

\footnotetext{
5 Una síntesis, crítica, en Chapman 1991: 78-79.
} 


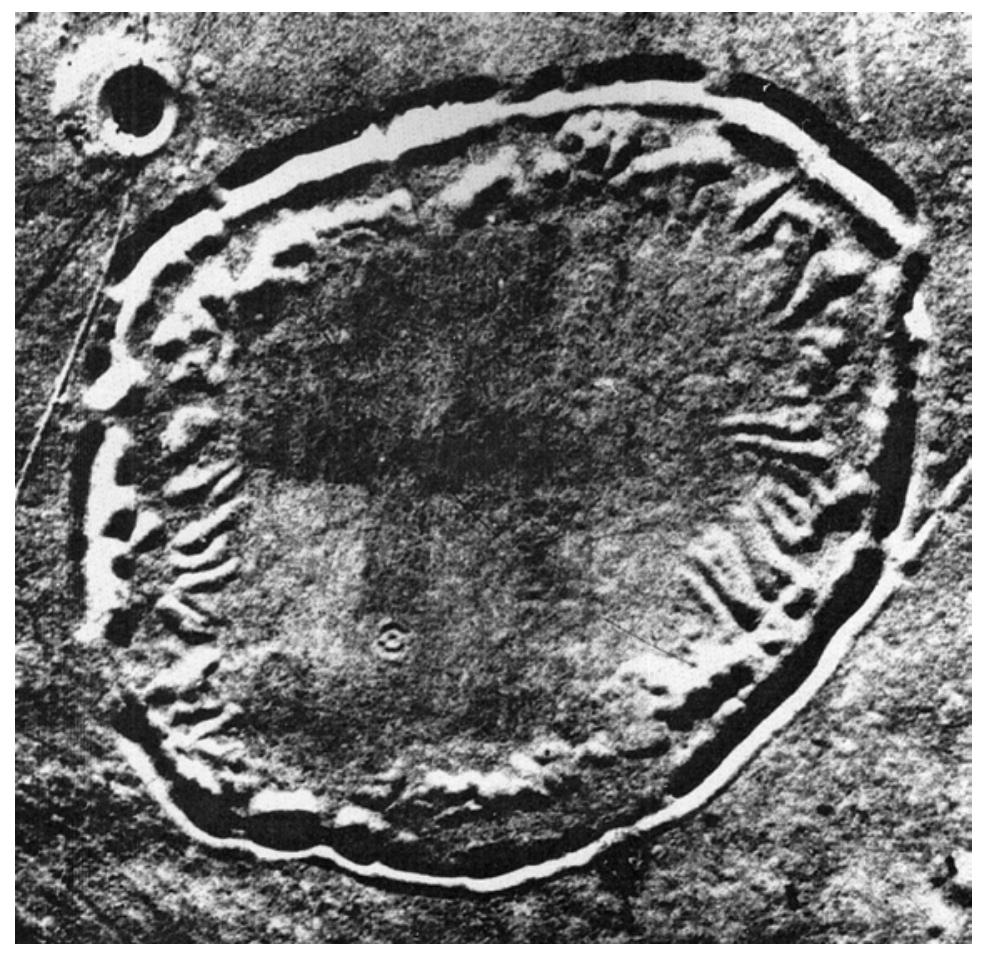

Lámina 2. Castro de Ladle Hill, Hampshire, U.K., cir. 1930 (RCHME SU 4756/11: en Bewley 1994: 111).



Lámina 2.1. Muralla, berma y foso interior de Monte Novo (Évora, Portugal). En detalle, fragmento de mampuesto vitrificado (a) y adobe hecho cerámica (b) hallados sobre la muralla (triángulo blanco). Fotografías de Luis Berrocal-Rangel 2002. 
La distribución peninsular presentada en la figura 1.1 (que no pretende ser exhaustiva y que responde al uso del adobe, con o sin estructuras de madera, a partir de diferentes publicaciones compendiadas en Esparza 1986, Kalb y Höck 1987, San Miguel 1993, Moret 1996, Esparza y Larrazabal 2000 y Celis 2002) muestra cómo estas murallas se distribuyen, durante el Hierro I, en dos amplias franjas al Norte y al Sur de la Península, separadas por un significativo aunque en absoluto determinante vacío central. El foco septentrional se concentra, en parte, en la Cuenca Baja del Ebro (Els Vilars y La Pedrera -Lérida-, La Loma de los Brunos y Cabezo de Monleón -Teruel- y Puig Roig -Tarragona- y no creemos que tenga relación, ni técnica ni formalmente, con el desarrollo más occidental de la Cuenca Media-Alta de dicho río (Cortes de Navarra y Las Eretas -Navarra-, Sorbán -La Rioja-; Baraones? -Palencia-, La Campana de Argüeso -Cantabria-). Aquí se reconocen las citadas murallas de tipo «Soto», cuya relación va desde la oriental Pintia (Valladolid-) a las occidentales de Manganeses de la Polvorosa, Sacaojos y Ardón (León) o a las zamoranas de Moveros y La Armena.

2. Las murallas de piedra y madera, posibles soluciones similares al genérico «muro gálico» (especialmente los tipos Kelheim y Preist), fueron documentadas en yacimientos como Monte Bernorio en su conocido «Castillejo» (San Valero 1966: 14-23). La posibilidad de una construcción de esta estructura mediante el ensamblado de vigas de madera internas y paramento exterior, y relleno, de piedra fue coherentemente defendida por A. Esparza y no tiene contestación en contra, en parte, por la imposibilidad de rehacer las viejas excavaciones (Esparza 1982: 401-404; Martín Valls 1985: 82). No obstante no es extraño esperar el uso amplio de madera en empalizadas de coronamientos o estructuras adosadas al interior, como las reconocidas en los castros de Los Baraones (Palencia), Peñas de Oro o La Hoya (Álava), en los que las construcciones de madera y adobe asimilables a las soteñas están bien documentadas....: (Fig.: 1.2) - (Llanos 1995: 269 ss.; Moret 1991-a: 14-21).

Sin embargo la presencia de armazones de madera en estructuras más cercanas a los tipos europeos «Kelheim» y Preist» nos parece probada en algunos ejemplos puntuales como la muralla del Bronce Final del Chao Samartín (Asturias), con sus gruesos postes distanciados regularmente en los paramentos (Villa 2003: 177 y 2001: 393), o los que se pueden deducir en los castros con murallas vitrificadas del Suroeste peninsular, como Passo Alto (Moura) con su banda de piedras hincadas, o el Castelo Velho de Cuncres (Évora) con una imponente línea de muralla - de piedra pero también con adobes - precedida de talud y triple línea de fosos (Correia 1995: 251; Berrocal-Rangel 2003; Correia y Burgess e.p.), donde hemos reconocido un paramento interior adosado que interpretamos como base del camino de ronda. Estos, con el cercano caso del Alto de Castelinho da Serra (Évora), fueron los primeros de una corta serie incrementada con recientes hallazgos ya en territorio extremeño, como el castro del «Volcán del Gasco» (Díaz Martínez 2003). De igual manera, en la torre de entrada del Castrejón de Capote (Badajoz) fueron reconocidos agujeros de vigas que hemos identificado como mechinales del piso superior de ésta a semejanza de los conocidos en castros meseteños como Castilmontán (Guadalajara). No obstante, pese a lo atractivo del planteamiento, no creemos que tales ejemplos respondan a difusión centroeuropea alguna sino a una solución técnica convergente con otras de la Europa atlántica, compartiendo en todo caso un lato substrato indoeuropeo.

3. Parecido fue el desarrollo de la consideración de los paramentos múltiples a partir de su reconocimiento, por vez primera, en el castro de La Mesa de Miranda durante las excavaciones de J. Cabré (1930: 30 ss). Por la fecha de su hallazgo fue rápidamente calificado de «celta» y comparado con casos conocidos de la Galia (como Ambrusum y Roque de Viou: véanse en Treziny 1986: 197). Sin embargo, no se relacionó con otras presencias peninsulares tan antiguas como el mismo Los Millares, ni se conocía su perduración en los yacimientos del Bronce Tardío y Final de Andalucía (Setefilla, Los Alcores) e, incluso, de la Mancha 
(Arribas et alii, 1979: 75; Molina et alii, 1983: 307; Aubet 1983: 298). Cierto es que la incidencia mejor contextualizada se documenta en algunos castros meseteños, generalmente entre los siglos III y II a. C. como Sanchorreja y Chamartín de la Sierra -Ávila-; Bermellar Salamanca-; Suellacabras, Oceanilla y Catalañazor -Soria-; Plaza de Moros -Toledo- y, ya fuera de la Meseta, en El Jardinero -Cáceres- (Martín Valls 1985: 68; Bueno et alii 1988: 88; Moret 1991: 28; Álvarez-Sanchís 1999: 133; González-Tablas y Domínguez 2002). Aunque todos estos casos son poco menos que singulares, no es menos significativa su ausencia en los contextos ibéricos contemporáneos, donde se desconoce a partir del siglo $\mathrm{V}$ a.C. (Moret 1996: 82).

El mapa de dispersión reflejado en la figura 2 permite comprobar un esquema centrípeto marcado por líneas isotrópicas ${ }^{6}$ que funcionan a modo de «isofenas o isoglosas». Demuestran la existencia de un núcleo antiguo en el Sureste Calcolítico y del Bronce Inicial (A), y otros dos complementarios con los yacimientos del Bronce Final e Hierro I (B) por los ámbitos costeros mediterráneos (y sus penetraciones marginales por el Ebro y el Guadalquivir), y con los del Hierro II (C), por los meseteños y occidentales, hasta los citados casos salmantinos de Yecla y Saldañuela de Bermellar o el cacereño de El Jardinero. Tal dispersión es sólo indicativa de un posible comportamiento que, dada la dispersión de yacimientos en tiempo y lugar, puede modificarse con propuestas de apariencia menos difusionistas que apoyen otros focos diacrónicos o, incluso, soluciones convergentes tanto para los casos meseteños como para los del Ebro. Pero, por el momento, el modelo refleja una posible y lenta dispersión desde el Sureste al Noroeste peninsular.

4. El cuarto elemento «celta» es, posiblemente, el más representativo de esta corriente interpretativa difusionista. Los llamados chevaux-de-frise ${ }^{7}$ son, en realidad, campos de piedras hincadas que se disponen en barreras frente a los castros del siglo VI a.C. sorianos o frente a los galaicos-portugueses de épocas más diversas (ss. VI a.C. - I d. C.). Desde sus primeros estudios fueron identificados como una adaptación peninsular de ciertas defensas de madera hallstátticas (Hogg 1957; Harbison 1968....: Lorrio 1997: 90) y, así considerados durante varias décadas. Sólo cuando la investigación ha podido datarlos adecuadamente se observó la antigüedad comparativa y la mayor concentración numérica que ofrecían los casos atlánticos, replanteándose la difusión en sentido opuesto, ya desde Galicia como desde territorios británicos en los que se documentan (Savory 1975; Esparza 1986; y Raftery 1991.....).

Así durante los años ochenta del pasado siglo, cuando nuevos hallazgos contextualizados ampliaron el mapa de distribución y los rangos cronológicos, se comenzó a cuestionar las diferentes interpretaciones planteadas, sin que se haya aportado una postura aparentemente definitiva y, de ello, el «callejón sin salida» evidenciado en el coloquio monográfico recientemente celebrado en la Universidad de Lérida (Alonso et alii, Lleida 2003). Además del espectacular hallazgo de Els Vilars de Arbeca (Lérida), cuya cronología y relación con las poblaciones tardías de Campos de Urnas supone el caso más antiguo conocido (G.I.P. 2003), otro no menos singular y aislado supone el campo de piedras hincadas de Passo Alto, en el Suroeste peninsular, datado por un sondeo sobre la muralla en el Bronce Final (Soares 1986 y 2003). Pese a la limitada entidad de la actuación, que no afectó directamente a las piedras hincadas, la caracterización de las cerámicas halladas tanto en el sondeo como en los diferentes rastreos superficiales apoyan una datación similar a los ch.-f., aún cuando varios investigadores hemos considerado una fecha mucho más tardía para estas defensas, incluso de época republicana (Berrocal-Rangel 1992: 191; Correia 1995: 251). Y tampoco hoy podemos

6 «Dícese de la materia que, con respecto a una propiedad determinada, no presenta direcciones privilegiadas» (DRAE)

7 Deberían llamarse «estacadas» o «dientes de dragón», pues los chevaux-de-frise son elementos diferentes en estructura y capacidad, aunque de funciones similares (Quesada 2003: 89-90). 
rechazar totalmente tal hipótesis, porque su muralla fue afectada por la acción del fuego quizá de la misma forma que el Castelo Velho de Cuncres y Alto do Castelinho, ambas en ocupaciones prerromanas, como hemos defendido para otros casos en el Suroeste peninsular (Las Peñas, Batalla, Castillo de Reina...... Berrocal-Rangel 2003: 218).

En suma, la dispersión exhaustiva de ejemplos peninsulares (Fig.: 3) demuestra la existencia de tres grandes focos y su desarrollo en forma de isoglosas indicaría una posible evolución diferenciada a partir del Bronce Final - Hierro I en cada uno de estos tres, asociando el grupo «Soriano» a los ejemplos del Ebro y del Nordeste (Els Vilars y, más tarde, Pech Maho). No obstante esta última hipótesis, a modo de mera propuesta resultante de una «aplicación de superficies de tendencias», se basa en ejemplos demasiados escasos como para implicar una consecuencia sólida. Porque este comportamiento apoyaría más su interpretación como un recurso autóctono surgido en convergencia con diferentes focos atlánticos, como los localizados en Irlanda y Gran Bretaña. En ellos, no son pocos los ejemplos que parecen responder a un carácter plurifuncional. Así lo deducimos en Las Peñas de Aroche (Huelva), donde servían más para encauzar la aproximación ordinaria al poblado por el acceso mejor controlado por sus habitantes, que para evitar el acceso en un momento de sitio (Berrocal-Rangel 2003: 227 - vide infra). En tal sentido, el valor simbólico y ritual que F. Quesada apunta para algunos de ellos (2003: 95), cobra sentido si se recuerda la fuerte carga religiosa manifestada en los accesos de poblados galos e ibéricos, como Pech Maho (Moret 1996: 292-293). En suma, sólo podemos afirmar que las piedras hincadas fueron un recurso usado por las poblaciones hispanoceltas para organizar una aproximación exterior favorable para sus habitantes, ya sea en momentos de conflicto como en las actividades ordinarias, con un rango cronológico tan amplio que es posible que también respondiesen otras funciones, religiosas o rituales.

5. Las murallas de cajones han sido una referencia obligada en los escasos análisis sobre las defensas protohistóricas, en parte porque llamaban la atención por su elaboración compleja respecto al emplekton habitual y, también, porque habían sido localizadas en el siglo V a.C. en Mothya, una de las fortificaciones púnicas más conocidas (Treziny 1993: 46; Ciasca 2000: 63). Por ello se les adjudicó rápidamente tal origen sin contemplar otras posibilidades que, incluso, podrían haber considerado la muralla «helénica» y más antigua de La Heuneburg IV (Collis 1989: 132).

En la Península, la procedencia fenicia parece avalada por su constatación en la muralla antigua del Castillo de Doña Blanca -Cádiz-, en la Silla del Moro -Málaga- o en La Fonteta -Alicante-, marcando un área costera que tiene su contrapartida interior en los primeros oppida tartésicos (Niebla, San Cristóbal de Estepa....: Ruiz Mata et alii 1998; Ruiz Mata 2001: 263; Escacena y Fernández Troncoso 2002: 111 ss.; Pérez Macías y Bedia 1992: 380-382; Juárez et alii 1998: 20) ${ }^{8}$. Nítida es, también, la difusión desde el Sureste y hacia la Meseta que los ejemplos indígenas presentan a partir del siglo IV a. C. (Charpolar $\dot{i}$ ?, Torreparedones, Puente Tablas, Valdepeñas, Las Cogotas y Yecla de Yeltes: Camino 2000: 36-37; Moret 1996: 68-70; Ramallo et alii 1992: 110; Aguayo et alii, 1990: 249; Cunliffe y Fernández Castro 1987: 194; Vélez y Pérez 1986-1987; etc....). Por otra parte, la presencia más tardía de estas murallas, a partir de finales del siglo III a.C., a lo largo del valle del Ebro y en significativos yacimientos celtibéricos llevaron a considerarlas como una aportación helenística de la mano de los griegos emporitanos (Cabezo Miranda, Las Tijeras, Valdevallerías, Inestrillas, Numancia: Romeo 2002: 167-168; Jimeno y Arlegui 1995: 122; Asensio 1995: 350-352; Jimeno y Benito 1999: 228 ss.; Hernández Vera 1982: 133). Pero, en este sentido, cobra inte-

8 Aunque es posible que estos «cajones» indígenas no sean más que una aplicación parecida a la propiamente oriental, dada la sencillez técnica de este recurso. 

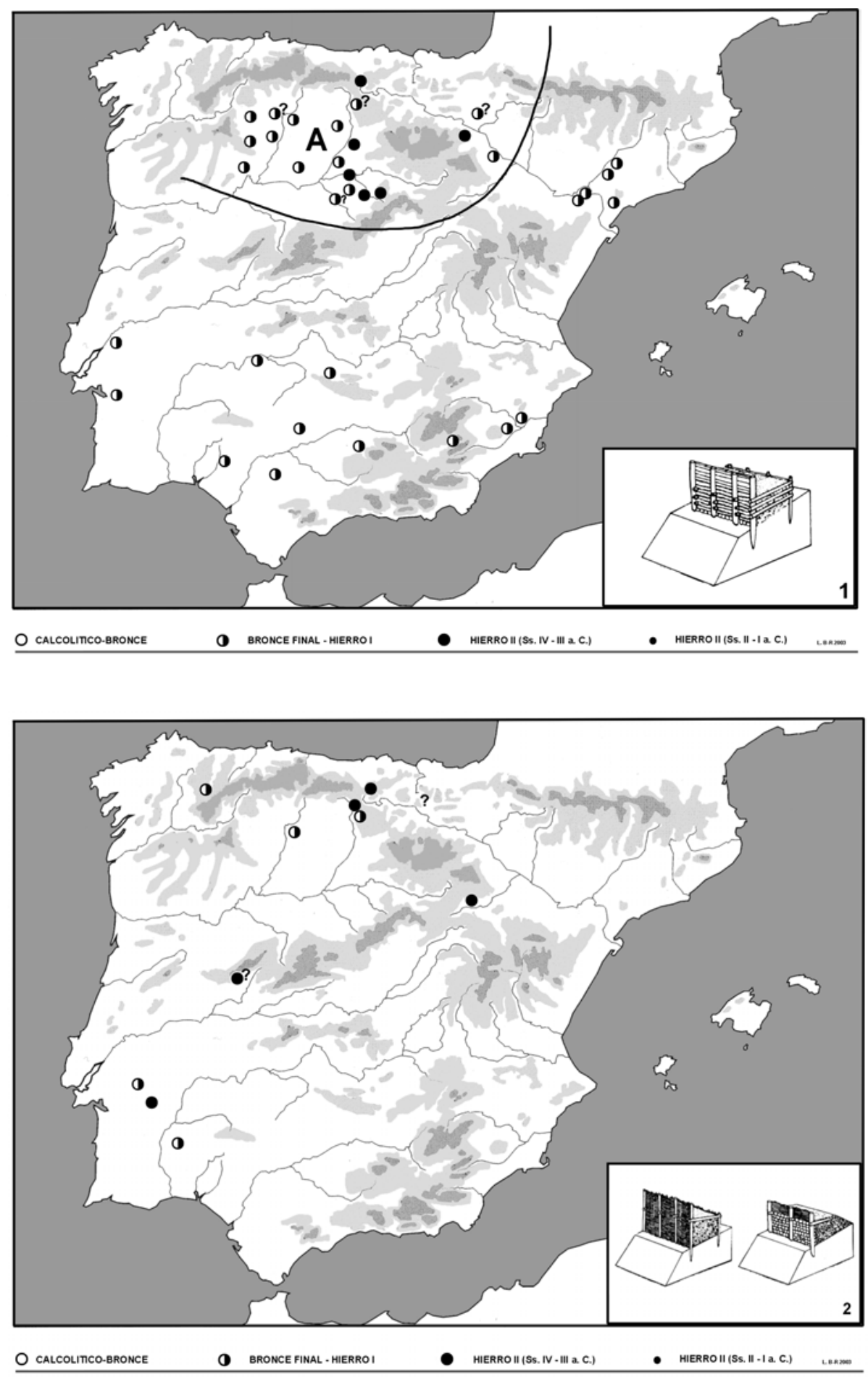

Figura 1: 1. Dispersión de las murallas tipo «Soto» y sus contemporáneas realizadas con adobes —pero técnicamente diferentes_-, a partir de Esparza 1986; Kalb y Höck 1987; San Miguel 1993; Moret 1996; Esparza y Larrazabal 2000 y Celis 2002; 2. Dispersión de las murallas de piedra y madera, de empalizadas y paramentos vitrificados, a partir de Berrocal 1992; Correia 1995; Celis 2002; Filloy y Gil 2000, y Villa 2002. 

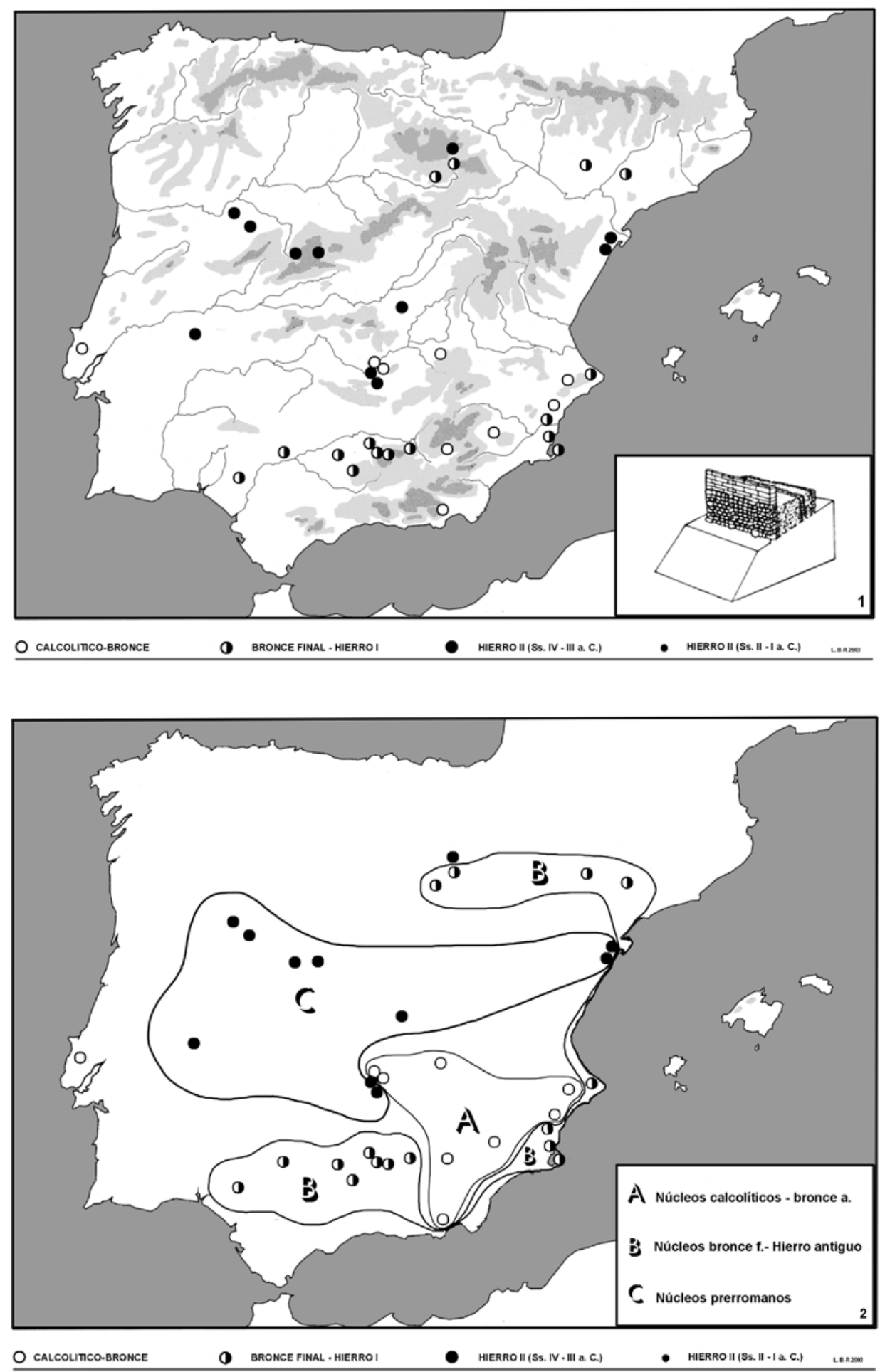

Figura 2: 1. Dispersión diacrónica de las murallas protohistóricas con paramentos múltiples a partir de las publicaciones recogidas en Martín Valls 1985; Bueno et alii, 1988; Blasco 1992; Moret 1996; Monton 1998; Álvarez-Sanchís 1999; y Martín Bravo 1999; 2. Distribución espacial agrupada según líneas isotrópicas funcionando a modo de isoglosas. 

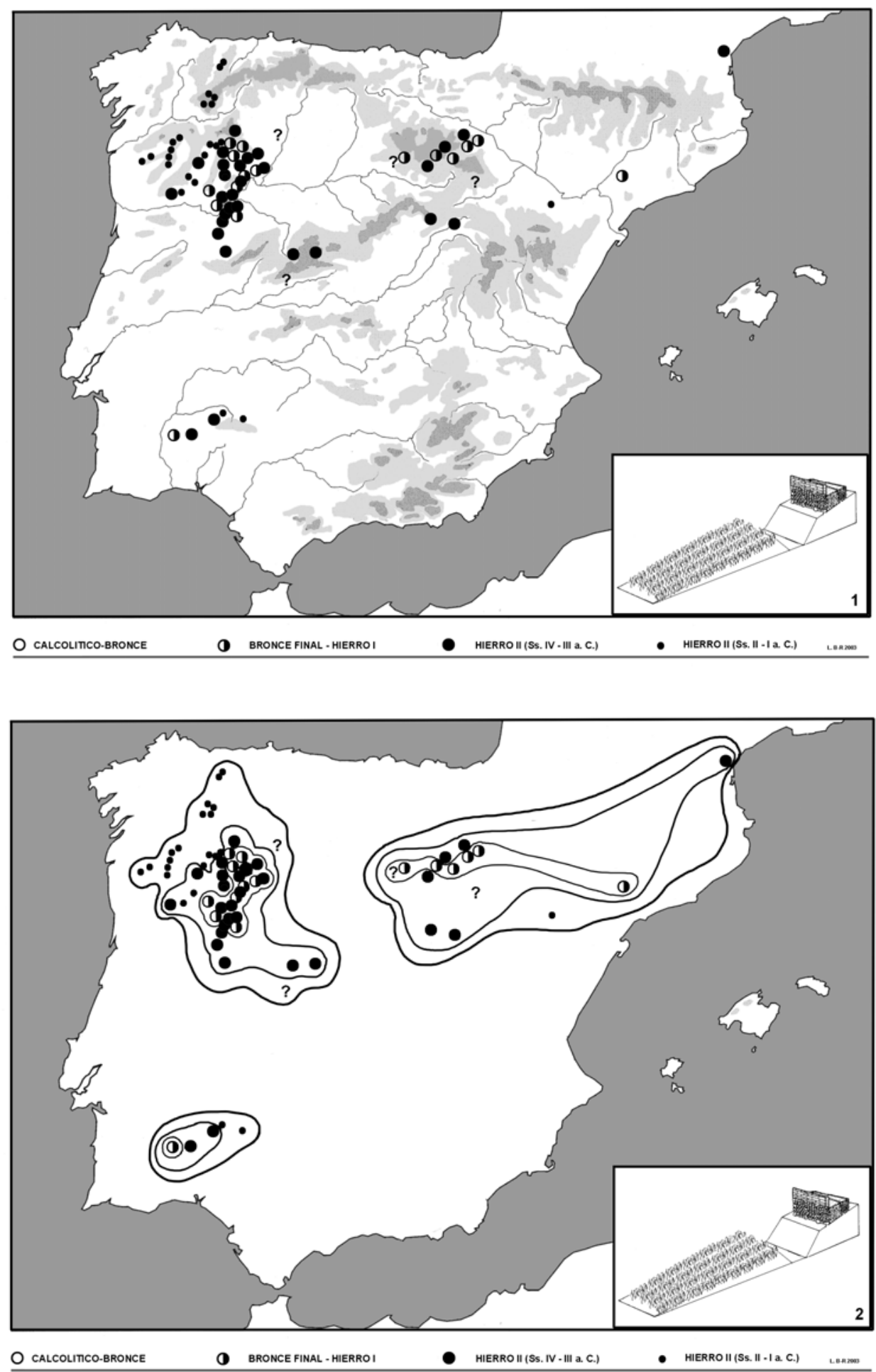

Figura 3: 1. Dispersión diacrónica de las defensas avanzadas con piedras hincadas, a partir de las publicaciones recogidas en Alonso, Junyent, Lafuente y López, eds., 2003, especialmente G.I.P., Romero, Esparza, Redentor y Berrocal-Rangel, 2. Distribución espacial en forma de superficie de tendencia de tercer grado. 



Figura 4: 1. Dispersión diacrónica de las murallas de cajones, a partir de diferentes trabajos recogidos en Cerdeño et alii 1995; Moret 1996; Belarte 1997; Camino Mayor 1999 y Romeo 2002; 2. Dispersión de las murallas de casamatas a partir de Berrocal-Rangel 1994; Moret 1996; Gracia 1997; Fabiâo 1998; y Ruiz Mata 2001, y de Fernández Ochoa, Hevia y Zarzalejos, inédito. 
rés la estructura perimetral excavada por S. Vilaseca en el poblado tarraconense del Coll del Moro de la Serra d'Almos (Belarte 1997: 40-41, fig.: 28.b), una sucesión de estancias rectangulares alargadas de $2 \times 1 \mathrm{~m}$. cuya cronología del siglo VI a.C. permite considerarla como precedente de estas murallas de cajones del Ebro sin necesidad de apoyar una influencia helenística, por otra parte indetectable en tierras tan interiores. Y, además, no debe olvidarse que la realización de una muralla con tramos reforzados mediante paramentos en perpiaño es una técnica elemental, destinada a reforzar la estructura de sus paramentos, y no puede sorprender que, independientemente de su procedencia, no implicase otra consideración cultural ni social que su mero uso técnico.

Por tanto, las murallas de cajones pueden comprenderse dentro de los préstamos fenicios que inciden en el Mediodía de la Península Ibérica a partir del siglo VIII a.C. y, aunque parecen penetrar hacia el interior de forma puntual alcanzando el Duero (Puente Tablas, Valdepeñas, Las Cogotas, Yecla), la cronología de estas presencias fechadas a partir del siglo IV a.C. hace factible suponer que pudo ser consecuencia de una innovación peninsular, aparentemente convergente en la forma con la fenicia, pero de la que quizá se distingue en funciones y detalles constructivos. Esta doble vía difusora se refrenda por una tercera, más tardía aún y centrada a lo largo del Valle del Ebro, que parece tener relación con las influencias y contextos helenístico-romanos desde finales del siglo III a.C. (p. ej. en Hernández Vera 2003) - (Fig.: 4.5).

6. A diferencia de la sencillez propia de la técnica anterior, las murallas de casamatas constituyen un verdadero recurso poliorcético que responde a una aplicación concreta y especializada. Esta función se relaciona con la necesidad y la capacidad de albergar contingentes de defensores en los puntos más débiles de las murallas, cuando no verdaderas baterías artilleras (Winter 1971: 328). Por ello, las casamatas o casernas son murallas «huecas» regularmente realizadas en todos sus paramentos exteriores e interiores, y no pueden confundirse con estancias interiores adosadas a la muralla o con los mismos cajones de otro tipo de murallas, como suele ocurrir en no pocos yacimientos peninsulares ${ }^{9}$.

Es seguro que las casamatas, tal como se conciben en la Poliorcética helenística, tuvieron una inspiración en las murallas de doble paramento fenicias pero su desarrollo no se constata hasta la expansión de la artillería de torsión a lo largo del siglo IV a.C. Por eso se conoce en la muralla helenística de Kerkouanne (Fantar 1986: 242; 2000: 72-73), que ha sido fundamental en su consideración púnica, aunque tal presencia corresponda al siglo III a.C. cuando la utilización de este recurso es panmediterránea. Aún así los casos de Doña Blanca, Carteia, Cartagena y, posiblemente, Tossal de Manises refrendan esta adscripción púnica en la Península Ibérica (Ruiz Mata 2001: 263-265; Roldán et alii, 1998: 156-157; Ramallo et alii, 1992: 110; Nogueras Celdrán 2003; González Prats 1997: 9; Olcina y Pérez 1998). No serán iguales otros ejemplos, que presentan cronologías mucho más avanzadas y emplazamientos interiores en contextos tardíos, propios de la misma Conquista romana o de las Guerras Civiles como pudieran interpretarse los tres casos conocidos en el Suroeste: la posible muralla de casamatas de Los Castillejos de Fuente de Cantos, en los límites orientales de la Beturia Céltica; la de Mesas do Castelinhos, en los meridionales de los célticos alentejanos y, posiblemente, la recientemente descubierta en La Bienvenida (Ciudad Real), la Sisapo de la Beturia Túrdula ${ }^{10}$ (Fernández Corrales et alii, 1988: 106; Fabiâo 1998: 311; Berrocal-Rangel 1994: 206 y fig. 9.3).

9 Por ejemplo, y sólo a modo de una cita más, el caso del Cerro de San Cristóbal de Estepa responde, según la descripción de los arqueólogos responsables de su excavación y las fotografías aportadas (Juárez et alii, 1998: 20), a una muralla de cajones, muralla que en el siglo VII a.C. es defendible dentro de la difusión meridional de esta técnica según se ha comentado en el apartado anterior.

10 Información inédita que agradecemos a sus excavadoras, las Dras. Carmen Fernández Ochoa, Patricia Hevia y Mar Zarzalejos. En este caso, la fecha pudiera retrasarse a finales del siglo IV o inicios del III a.C. respondiendo a un testimonio de la influencia bárquida por la principal vía de penetración en la Meseta que los Cartagineses pretendieron dominar. 
Sin duda la expansión hacia el Interior peninsular de un recurso tan especializado, y relacionado con la puesta en marcha de la artillería de defensa y asedio, incluye un cuarto caso indígena y costero, el Turó del Montgrós (Girona), datado a lo largo del siglo III a.C. en las cercanías ampuritanas (Molist y Rovira 1990: 255). En él se confirma una tercera adscripción, helenístico-emporitana en este caso, con éxito hasta promover su copia adaptada en yacimientos iberos vecinos como Puigcastellet y L'Esquerda, que hemos incluido en el mapa de dispersión de la figura 4.2. Tal como ha puntualizado P. Moret, estas últimas murallas no son de casamatas aunque parecen inspiradas en el ejemplo del Turó y responderían a un modelo de fortificación específicamente ibero, ausetano en este caso (1996: 84 y 2002: 211).

En suma la dispersión de las murallas de casamatas (Fig.: 4.6) demuestra la clara relación de éstas con los establecimientos coloniales de época avanzada, fundamentalmente púnicos (Carteia, Cartago Nova) pero también «helénicos» (Emporion, Montgrós.....) , y con las vías de penetración de la Conquista romana de primera época, entre finales del siglo III e inicios del II a.C., cuando se usaron las primeras máquinas de artillería de torsión.

7. También el llamado aparejo ciclópeo, por el uso de mampuestos con medias superiores a $1 \mathrm{~m}$. en longitud o altura, ha sido adscrito a los púnicos al ser identificado en algunas torres jienenses y cordobesas, reconocidas sin base suficiente como las turres Hannibalis de Plinio (Fortea y Bernier 1976; Moret 1990). Pero, por el momento, el testimonio más antiguo y mejor datado de esta técnica aparece en la muralla del siglo IV a. C. de Emporion y muestra, a partir de ella, una clara y dispersa repercusión en otros yacimientos costeros e interiores: Ullastret, La Creuta, Sagunto, El Molón, El Higuerón, Cerro Minguillar.... (Moret 1996: 200-201). Antes de todos estos testimonios, el uso de aparejo ciclópeo se documenta en recintos del Bronce Final e Hierro Antiguo tan alejados como el oppidum de Agde (Herault) o el poblado de Castillico de Moratalla -Murcia-, pasando por Tossal Redó -Teruel- y Alhonoz (Moret 1996: 87). Se trata por tanto de un elemento sencillo, idóneo para proporcionar a cualquier muralla un deseado aspecto monumental, y capaz de ser ideado y utilizado de forma autónoma por las poblaciones indígenas, especialmente sí, como en el Castillico de Moratalla, la base basáltica del lugar lo facilita. Esto descarta su uso en el litoral mediterráneo peninsular como reflejo del deseo de emulación provocado por las murallas de Emporion. Por tanto, no sólo es un elemento difundido a partir del siglo IV a. C. desde la Poliorcética helenística en general como ha considerado J. A. Asensio (1995: 346). Así la distribución de estos aparejos muestra una variedad coherente con su propio polimorfismo, señalando, mediante la aproximación de un mapa de superficies de tendencias ${ }^{11}$, al menos siete focos de uso, con yacimientos reconocidos desde el Bronce Final a la época romana (Fig.: 5). De estos, los denominados F y E, situados en el Valle del Ebro y litoral catalán, se relacionan con el contexto helenístico ampuritano comentado, independiente del foco más antiguo representado por Tossal Redó, El Cerrao -Teruel- y Herrera de los Navarros -Zaragoza-, cuya estructura ortostática parece tener un desarrollo diferente en yacimientos cercanos y más tardíos como La Gessera. En este sentido, un último grupo $\mathrm{G}$ representado por los castros abulenses de Chamartín de la Sierra y de Cillán —y quizá el segoviano de Sampredros—, refrenda el uso independiente de ortostatos para los paramentos de base, técnica espectacular, aunque singular y siempre documentada en contextos petrológicos favorables como los citados del Bajo Ebro (Moret 1991: 27; Barrio 1999: 174; Moret y Benavente 2000: 333). Al margen de los anteriores, los casos más antiguos se emplazan en pleno Bronce Final o Hierro I del Bajo Guadalquivir $^{12}$ (con emplazamientos como Tejada la Vieja -Huelva- y Alhónoz -Sevilla-) y

11 No aplicamos un análisis de tendencias (Hodder, I. y Orton, C., 1992: Análisis espacial en Arqueología: 172 ss.), por considerarlo innecesario en este tipo de datos, pero sí su concepto y representación gráfica.

12 Pues Tossal Redó viene a fecharse entre los siglos VI y V a.C. 



Figura 5: 1. Dispersión diacrónica del uso de aparejo ciclópeo (y ortostáticos -0-) usados en las murallas protohistóricas, a partir de diferentes trabajos recogidos en Moret 1996; Lorrio 1997 y Berrocal 1992; 2. Distribución de tal dispersión en forma de superficie de tendencias. 



Figura 6: 1. Dispersión diacrónica de las obras cuadrangulares en las fortificaciones, a partir de diferentes trabajos recogidos en Poblamiento Celtibérico 1995; Moret 1996; Lorrio 1997; Burillo 1998; Martín Bravo 1999; y Peralta 2000; 2. Distribución de tal dispersión en forma de superficie de tendencias (emplazamientos coloniales) 

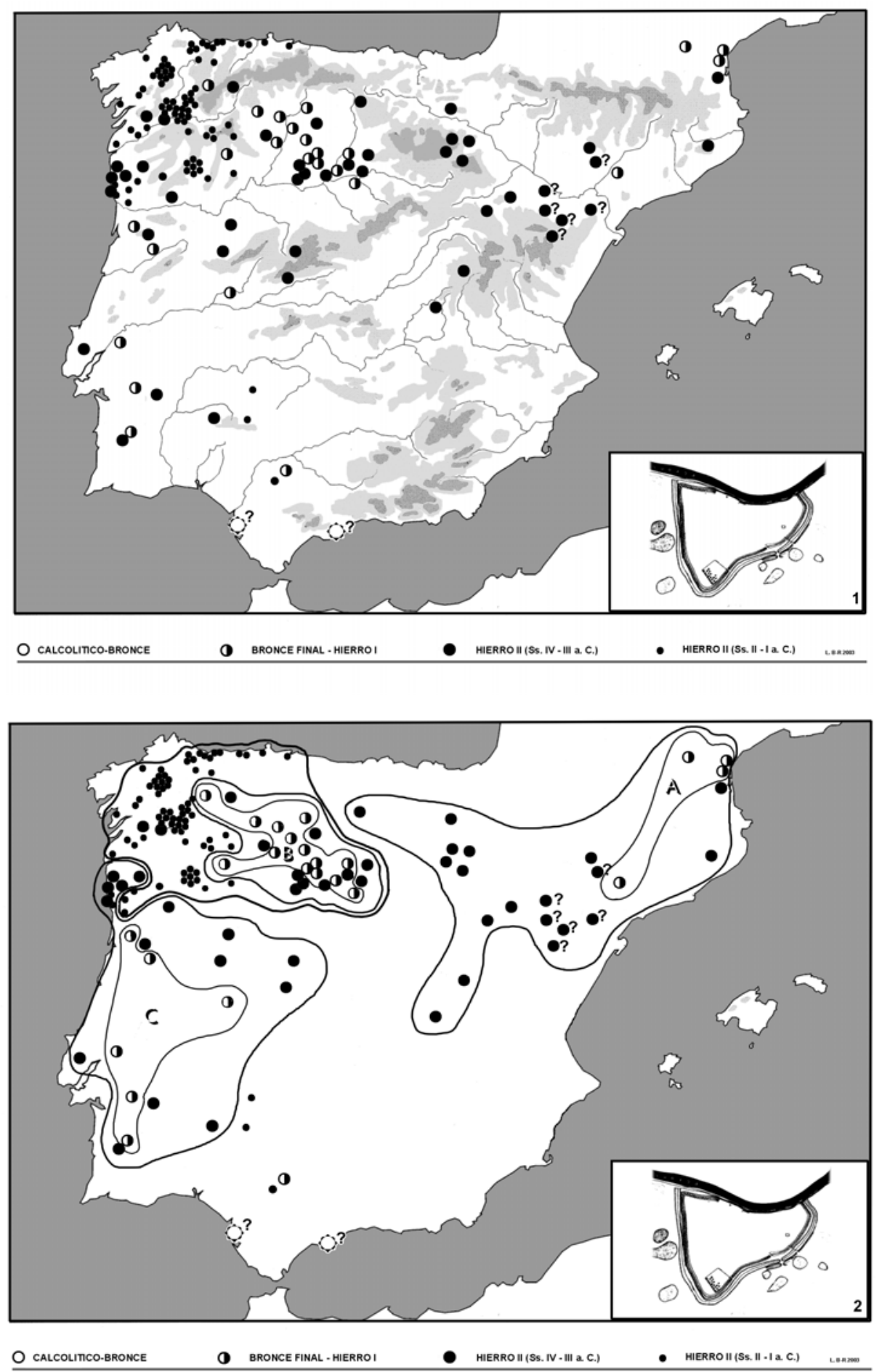

Figura 7: 1. Dispersión diacrónica de los poblados con fosos «perimetrales», a partir de diferentes trabajos recogidos en Romero 1976; Esparza 1986; Paleoetnología de la Península Ibérica 1992; San Miguel 1993; Poblamiento Celtibérico 1995; Camino 1995; Moret 1996; Lorrio 1997; Burillo 1998; Pereira Dinis 1999; Álvarez-Sanchís 1999; Martín Bravo 1999; SánchezPalencia et alii 2002; y Celis 2002; 2. Distribución en forma de superficie de tendencias. 

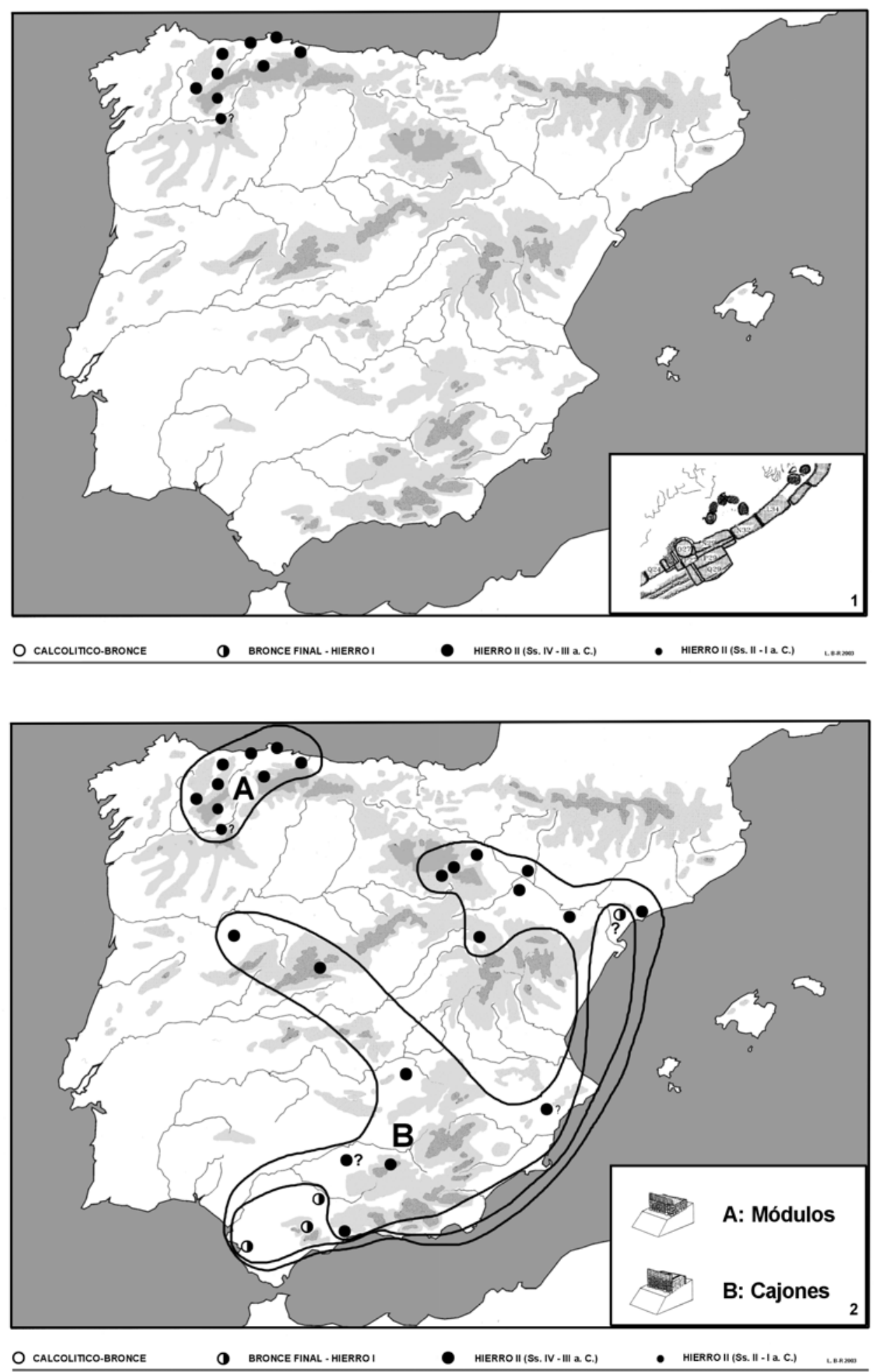

Figura 8: 1. Dispersión de los poblados con murallas de módulos o compartimentadas-, a partir de Camino 1999; y Sánchez-Palencia et alii 2002 (en el caso cuestionable de El Castrelín •?); 2. Relación de la distribución de las murallas de módulos respecto a las de cajones. 
en el Sureste, cuencas del Segura - Vinalopó (donde el citado Castillico de Moratalla -Murciaimpone un punto inicial de evidente interés).

En suma creemos que, en modo similar a las murallas de cajones, el aparejo ciclópeo es un recurso que responde a diversas génesis y momentos de expansión, algunas de ellas independientes de las corrientes difusoras mediterráneas aún cuando en los siglos más tardíos se implique en ellas, en este caso a causa del factor de emulación que supone Emporion en el Nordeste.

8. Las obras cuadrangulares (torres, bastiones, cuerpos de guardia.....), por último, se han considerado siempre como una verdadera aportación de origen oriental frente a la tradicional planimetría curvilínea o las construcciones de esquinas achaflanadas o subrectangulares, tal y como sucedería en la Grecia del siglo VI a. C.(Winter 1971: 292 ss.; Garlan 1974: 151-152; Adam 1982: 48-49).

Pero la verdadera importancia de la construcción cuadrangular en las fortificaciones de la Península Ibérica no ha sido destacada hasta la obra fundamental de P. Moret, donde se demuestra cómo la aportación oriental consistió en la construcción de las esquinas con sillares trabados o encadenados a soga (chaînage d'angle), una técnica difundida desde Oriente por todo el Mediterráneo y cuya relación con las vías de penetración fenicia parece fuera de toda duda (1996: 209). El mismo P. Moret, en el recuento de tales obras, ya torres como bastiones, cremalleras u otros quiebros de la cortina muraria, aporta una dato concluyente: sobre los más de 400 yacimientos inventariados en su estudio, la presencia de estas obras supone el $9 \%$ de los poblados durante el período «Pre-ibérico» frente al 52 \% que alcanza durante el Ibérico pleno (1996: 205), siendo el siglo VI a.C. - como ocurriría en la misma Grecia tras el proyecto pionero de Polykrates (Winter 1971: 294)—, el período crucial para la expansión exitosa de esta técnica constructiva (Fig.: 6).

La aceptación de estas esquinas con aparejo encadenado se demuestra por su extensión y dispersión en un breve período de tiempo, además de por la aparición de adaptaciones indígenas que demuestran la rápida asimilación de modelos de torres de planta cuadrada compleja, como las que vienen denominarse «compartimentadas» por albergar dos o cuatro estancias en su interior. Algunos ejemplares en yacimientos significativos como los gerundenses de Alorda Park y Ullastret responden a patrones métricos de origen griego, mientras la torre $\mathrm{n}^{0} 3$ de Torreparedones -Jaén-, la más espectacular de todas, es identificada por P. Moret como construida canónicamente según patrones greco-sículos, en codos púnicos (51,4 cm.), lo que refuerza la posibilidad de su concepción a mano de especialistas de este origen o de veteranos mercenarios enrolados en sus ejércitos (Moret 2002: 207-209; Karlsson 1992).

En suma, la distribución de las obras cuadrangulares en las fortificaciones muestra áreas de tendencias susceptibles de ser interpretadas como el reflejo más nítido de un elemento alóctono difundido desde diversos focos a través de amplias superficies de dispersión y escasa concentración (Fig.: 6). Además, la clara relación de éstas con las tres vías de penetración mediterránea más destacadas a partir de los establecimientos coloniales conocidos desde Rhode y Emporion a Tavira y Abul, reafirma la raigambre fenicia o griega de estos elementos, como demostró P. Moret (1996: 210-211). Esta distribución permite seguir, mediante las agrupaciones marcadas por las líneas «isotrópicas», las vías de difusión en forma de una superficie «A» localizada a partir del Sur-Suroeste (Tejada la Vieja -Huelva-, silla del Moro -Málaga-), con desviaciones hacia la desembocadura del Tajo, por un lado, y el Alto Guadalquivir, por el otro, pero también con una clarísima penetración a lo largo de la llamada Vía de la Plata hasta el Tajo. Más arriba, la constatación de obras cuadrangulares parece esperar a la Conquista romana. Un segundo foco (B) se sitúa en el Segura - Vinalopó, avanzando por el Alto Guadiana (Benimaquía, Tossal de Manises-Alicante-; Moratalla -Murcia-; Sisapo -Ciudad Real) y el tercero (C) engloba el Nordeste, penetrando por el Ebro (Alorda Park, Molí d’Espigol, San Antonio de Calaceite, Las Eretas....) hasta el mismo Cantábrico, donde La Ulaña (Burgos) y Monte Bernorio (Palencia) tienen su continuidad en el castro cántabro de Castilnegro. 
El panorama descrito por estos 8 elementos, convencionalmente considerados alóctonos, podría ampliarse con otros como las cortinas en cremallera, las puertas con patio o los antemuros de calificada procedencia colonial, al menos conceptualmente. Y frente a todos ellos son muy escasos los recursos defensivos considerados a priori como plenamente autóctonos, en cuanto a su concepción y desarrollo en el suelo hispánico. Por ello para este análisis, que busca comprobar el comportamiento comparativo sobre una muestra significativa de unos y otros, nos hemos inclinado por dos de ellos, los fosos de desarrollo perimetral y las llamadas «murallas de módulo» astures.

9. Los fosos múltiples con parapetos o taludes fueron sin duda uno de los primeros elementos delimitadores y defensivos del poblamiento y, por ello, es fácil apoyar su indigenismo, especialmente cuando se comprueba cómo siguieron en uso durante el Bronce Pleno y Final, aún cuando el relieve de la Península los hace, a veces, innecesarios; otras, indistinguibles; $y$, en la mayoría de los casos, costosos de excavar ${ }^{13}$. Sin embargo la generalización de las fortificaciones entre los siglos VI y V a.C. pone en evidencia que el comportamiento y la estructura formal de los fosos diverge mucho según el territorio estudiado y, en este sentido, sí se observan claras diferencias entre el poblamiento atlántico, el meseteño y el propiamente ibero. Así, entre estos, la presencia de fosos no es determinante de la fortificación y, aunque cada vez son más abundantemente los conocidos en el Valle del Ebro, suelen restringirse a la cava de una línea que separa el poblado por su acceso (Moret 1996: 125; Romeo 2002: 157-164). Más al interior, conforme se avanza hacia el Atlántico, se observa la extensión del foso en longitud hasta circunvalar parcial o totalmente la muralla, la proliferación de varias líneas más o menos concéntricas, su asociación a parapetos o taludes, y su generalización hasta convertirse en el elemento característico de la Arquitectura defensiva castreña, por encima de la muralla de piedra y madera (como ya planteaba A. Romero Masiá 1976: 21ss.). Es muy probable que la extensión de la «técnica minera» de época romana sea responsable de la proliferación de poblados castreños circunvalados por tres, cuatro, y hasta cinco líneas de fosos de secciones acusadas en «V» $\mathrm{y}$ anchuras considerables, en disposición de «ocelo» (Calambre -Asturias-; Truchas -León-; San Cibrán de Lás -Orense-, Torre dos Mouros -Orense-; Carvalelhos -Porto-.....: Camino 1995: 164; Sánchez-Palencia 2002: 253), pero no caben dudas sobre la existencia de las tramas múltiples en poblados muy anteriores, ya castreños o soteños con similares fosos en «V» (Villa 2002: 174; Celis 2002: 100 ss.; Bewley 1994: 100), como en ámbitos celtibéricos (Fosos de Bayona: Mena et alii 1987) y célticos, desde el Bronce Final (Alpiarça -Santarém-; Corôa do Frade -Évora-, Outeiro do Circo -Beja-: Pariera y Monges 1980; Kalb y Höck 1987; Berrocal-Rangel 1992: 215). Es difícil relacionar alguno de estos ejemplos con una posible difusión orientalizante antigua, bien porque entre las fortificaciones turdetanas los fosos son especialmente extraños, bien porque los casos conocidos de raigambre helenística en las costas catalanas y valencianas no pasan de ser aplicaciones muy concretas y singulares (Emporion, Ullastret, Turó del Montgrós, La Pícola.....: Moret 1996: 214-216; Gracia 2000: 150 y 1997) ${ }^{14}$. De igual forma algunos casos extremeños como Hornachuelos o Regina muestran restos materiales que los definen como emplazamientos romanos republicanos y, por ello, aunque indicados no se han relacionado con el foco occidental.

13 Los ejemplos calcolíticos son reconocidos en numerosos ámbitos peninsulares y europeos en general, algunos con ejemplos tan remarcables como los que flaquean la muralla de Marroquíes Bajos a finales del III Milenio (Zafra et alii, 1994 y 2003; Díaz-Del Río 2003; Jorge 2003.....).

14 Al fin y al cabo el foso no era un elemento desconocido en Grecia antes del siglo VI a. C. aunque es significativa su aparición, tildada de innovación, en el primer gran programa defensivo, el construido por Polykrates de Samos entre el 530 y el 525 a.C. (Winter 1971: 295). Aún así no será un elemento habitual en la Poliorcética helena hasta ser integrado en los sistemas complejos helenísticos de defensas avanzadas, extendidos por el Mediterráneo a mediados del siglo IV a.C. (Adam 1982: 112). 
El mapa de dispersión representado en la figura 7 muestra la distribución eminentemente septentrional de este elemento del que, sin ser exhaustivo, se han considerado todos los ejemplos con fosos perimetrales o, al menos, parcialmente perimetrales en el sentido de cubrir uno o dos flancos del poblado. No se han tenido en cuenta numerosos casos en Aragón, Extremadura y el Noroeste, en los que los fosos se emplazan sólo frente al acceso principal del poblado, generalmente situado en uno de sus extremos, pues se considera que este recurso es, en esencia, diferente del que pretende reforzar el perímetro amurallado de un poblado mediante una cava en paralelo. Aunque otros componentes como la base geológica de la comarca en estudio condicionan en mucho estos resultados, la identificación de al menos tres focos aparece con cierta claridad en el mapa peninsular: el foco mediterráneo (A), extenso y quizá abordando de forma forzada tanto los casos catalanes como del Valle del Ebro, que difícilmente se distinguen de la diferencia expresada. El foco nordoccidental (B), muy nítido en relación con el Hierro I del Duero Medio, poblados «Soto» que parecen ser sucedidos o complementados en el tiempo por otros castreños nordoccidentales para proliferar posteriormente en tales ámbitos; y el foco occidental (C), con los ejemplos del Bronce Final - Hierro I citados y su distribución más extensa durante el Hierro II hacia el Norte (Periñuelo -Cáceres-; Plaza de Gallegos y Picón de la Mora -Salamanca-, y el Raso y Chamartín -Ávila-), para culminar en los castros de la desembocadura del Duero.

En suma, una distribución compleja que se manifiesta extraña a los territorios mediterráneos peninsulares si no fuera por los escasos ejemplos fenicios antiguos, y en cierto sentido por la distribución del foco «A» nordoriental expandidos ${ }^{15}$. Pero, sean estos considerados como expansión desde el Sur de la Galia como reflejo de una autoctonía lógica, los fosos perimetrales se revelan como un recurso fuertemente difundido por el territorios atlánticos peninsulares, funcionando de igual manera similar a los llamados «chevaux-de-frise».

10. El segundo elemento indígena, las murallas de módulos, presenta tales características innovadoras y una dispersión cronológica (Ss. IV a.C. - I d.C.) y geográfica tan concreta, que es fácil la valoración de su personalidad cultural y su adscripción a la inventiva de los astures, como propuso J. L. Maya (1983: 299)-(Fig.: 8). En efecto se trata de cortinas organizadas en módulos macizos, a menudo independientes, documentadas entre los siglos IV a.C. y I d.C. en las cuencas del Cantábrico occidental (Navia, Nalón y Sella, con algún ejemplo aledaño como el castro del Chano, en León). Por ello es un recurso constructivo tan característico y concentrado que parecería responder ejemplarmente, a diferencia del anterior, al desarrollo de un elemento autóctono, si no fuese porque ha sido interpretado como una adaptación de las murallas de cajones como ha propuesto en una interesante síntesis J. Camino Mayor (2000: 36-37).

Hay sin embargo consideraciones en contra, que el mismo Camino plantea. Es el caso de no poder resolver las lagunas intermedias entre las primeras, en cuanto a la geografía, y las segundas, en cuanto a que las murallas astures son más antiguas que los ejemplos celtibéricos conocidos (Romeo 2002: 168), los más cercanos y acordes para una vía de llegada al territorio astur. Además consideramos que, pese a cierta similitud conceptual, ambas soluciones son aplicaciones técnicas diferentes, radicando la de cajones en un recurso para fortalecer un lienzo de muralla continua en sí y, la de módulo, en una solución para facilitar el drenaje de aguas, el mayor enemigo de la estabilidad de la cortina muraria en tiempos de paz (Adam 1982: 16), especialmente en un territorio tan lluvioso como el asturiano, donde además el subsuelo de base arcillosa es especialmente blando e inestable. Por ello los recursos para evitar desplomes mediante contrafuertes y paramentos múltiples, aterrazamientos y adecuados sistemas de drenaje serán una constante en las fortificaciones complejas astures (Be-

15 Mal conocidos y escasamente excavados en general, aunque presentes con sus secciones en «V» en yacimientos tan representativos como Toscanos y Castillo de Doña Blanca: Ruiz Mata et alii 1998: 72. 
rrocal-Rangel et alii 2002: 102). Aún así la interpretación de J. Camino es plausible porque, antes del siglo IV, los pequeños tramos de murallas conocidos en el territorio astur son lienzos continuos sin aparentes compartimentaciones (Camoca, Olivar de Villaviciosa, Llagú.....) y porque, en algunos casos, los módulos no son tales, presentando sólo las divisiones bien por el paramento externo o por el interno de la muralla (Camino 2000: 39; Villa 2002: 177179). Claro que este argumento puede esgrimirse en el sentido contrario.

En conclusión, el análisis de estos diez elementos arquitectónicos demuestra el comportamiento no reglado y el carácter difundido de la mayoría de ellos. Muchos con precedentes peninsulares desde el Calcolítico y una continuidad de uso más o menos comprobada y, otros, de procedencia alóctona como las torres compartimentadas. Pero todos ellos muestran su personalidad específica, fruto de la capacidad indígena para la adaptabilidad y de un fortísimo desarrollo difusor, según demuestran los patrones de distribución sea el origen extrapeninsular o local. Este desarrollo utiliza tanto las vías marcadas por las cuencas de los ríos principales (EbroDuero, y el Guadalquivir) como las rutas consagradas del interior peninsular (p.e., la «Vía de la Plata»). Tal constatación reafirma los resultados de la primera premisa, la generalización del poblamiento fortificado tras un período de especial aperturismo económico.

Incluso cuando se analiza un elemento tan específico, en el tiempo y en el espacio, como las murallas de módulos astures no es posible negar que pudieran gestarse como una adaptación local de difundido sistema de «cajones». De igual forma, y a excepción de las obras cuadrangulares y de las casamatas, los focos difusores de los elementos analizados son polivalentes, combinando según las zonas y los momentos, la tradición e inventiva autóctona con los préstamos alóctonos básicamente del Mediterráneo, aunque tampoco deberían descartarse algunas influencias continentales a través del corredor catalán. Un único elemento, los llamados «chevaux-de-frise», refleja un comportamiento radicalmente diferente, con una distribución centrada en tres densos focos inconexos, de hallazgos limitados en extensión pero duraderos en el tiempo. La dispersión de uno de ellos, a lo largo de la cabecera del Duero y su proyección por todo el Ebro hasta el Languedoc, es más aparente que real, motivada por tres ejemplos dispersos no contemporáneos (Arbeca - Azaila - Pech Maho)

Con independencia de la escasamente conocida poliorcética fenicio-tartésica fechada en el Valle del Guadalquivir desde finales del siglo VIII a. C., y cuyas perduraciones genéricas afectarían a las defensas de los oppida indígenas posteriores, sólo a partir del siglo IV a. C. se observa la presencia conjunta de elementos de la poliorcética helenística como las murallas de casamata, los fosos asociados a antemuros y posiblemente algunas murallas de cajones. Pero su penetración hacia la Meseta y el Atlántico es, por el momento, muy escasa y puntual (muralla de cremallera: Guijosa; los fosos y antemuros de El Molón y Capote; y las murallas de casamatas de Fuente de Cantos?, Sisapo, Cerro de las Cabeza; ....y algunas más de cajones: Inestrillas, La Tijera, Numancia.....).

Por tanto, el origen alóctono y el comportamiento difusor de todos estos elementos no van de la mano de una expansión de sistemas o conceptos concretos, sino que es producto de un alto grado de adaptación local, inconexa e independiente, de ideas y técnicas, lo que confirma la naturaleza del proceso analizado pese a su alta tendencia a la difusión y al origen extrapeninsular, mediterránea fundamentalmente, de la mayoría de los elementos analizados.

\section{II.3. De los valores plurifucionales de las fortificaciones protohistóricas}

\subsubsection{Del valor activo como factor de cohesión comunitaria}

El tercer postulado se apoya en la naturaleza monumental de las murallas, ya por sus dimensiones como por su concepto constructivo (Trigger 1990: 128). Este carácter, y la natura- 
leza indígena del proceso analizado en el apartado anterior, es una justificación razonable para suponerlas como elementos fundamentales para la cohesión comunitaria, planteamiento confirmado por la fuerte carga ideológica que desprende el ritualismo asociado a las murallas (Fustel de Coulanges 1864 [1983]; Bendala 2003: 13-14).

La documentación de datos a favor de tal constatación es relativamente fácil desde la Etnografía, que permite comprender cómo pudieron funcionar los derechos y deberes de los miembros de la comunidad en relación con su defensa. Tal es el caso contemplado en los llamados Fueros de Extremadura, que pueden considerarse una versión medieval de parte de la consuetudinaria céltica, como propone el prof. Almagro-Gorbea en sendos trabajos (1994 y 1995). En tales Fueros se recoge cómo todos los vecinos «con hogar» tenían la obligación de construir, mantener y reparar las murallas «a pechas», siempre que fueran habitantes de las aldeas y no de la ciudad, porque estos estaban exentos de tales obligaciones a cambio de gestionar su uso (Almagro-Gorbea 1994: 49 y 54 ; y 1995: 435; Otegui, 1986).

Mayor interés, por la contemporaneidad que implican, presentan los restos supuestos de dicha asunción colectiva en la Protohistoria, búsqueda que siempre encuentra el inconveniente de la naturaleza del fenómeno constructivo. Hay, no obstante, algunos casos afortunados que reflejan un estado intermedio o inacabado de tal proceso, como pudo ocurrir en un ejemplo «histórico», el foso de Ladle Hill (Hants, Hampshire), que fue excavado en tramos regulares de disposición continua según se observa en las fotografías áreas, dato interpretado por S. Piggott cómo resultado de ser haber sido excavado por diferentes grupos de una comunidad (Piggott, 1931: Hogg, 1975; Cunliffe 1978: 188 ss.; Bewley 1994: láms.: 78 y 79). Un caso similar se puede observar en Hod Hill, Dorset (Bewley 1994: lám. 68), o ha sido interpretado en el registro del poblado francés de Cros de Caunes, cuya muralla fue construida a finales del siglo VII a. C. dejando patente en sus terreras las demarcaciones equidistantes de sus sectores (Gasco 2000: 184-185 y fig.: 2).

La idea, que tiene sus precedentes remotos en monumentos y casas «comunales» del Neolítico (Castleden 1993: 39 y 212), fue recogida por investigadores franceses y españoles para interpretar la singular imagen paritaria que se desprende de cierto tipo extendido de poblado ibérico, aquél que M. Py se viene a denominar «village clos» en el Languedoc o «poblado cerrado» (con medianiles comunes-o de calle o espacio central) en el Valle del Ebro, la Meseta Oriental y Levante peninsular (Py, 1990: 167 y Almagro-Gorbea, 1994: 48, respectivamente). En efecto, en versiones sencillas como las de La Bastida y la Quéjola, asumen la defensa con las paredes traseras de sus casas que, unidas, conforman el recinto exterior y que, por lo mismo, deberían haber sido resultado de la responsabilidad de cada núcleo familiar a la hora de construirlo y mantenerlo (Moret 1996: 267-268). Esta idea no entra en contradicción con el ejemplo astur de Borrenes, pues también en él se presupone la organización de la superficie a edificar en función del trazado más conveniente para la muralla y, de hecho, los indicios de una construcción mancomunada de la cortina muraria lo ofrece, mejor que ningún otro, el sistema de «módulos» astur ya comentado (según plantea J. Camino, 1995: 164). Incluso tal valor aglutinante llega a ser la razón final, y única, que se encuentra para algunas fortificaciones cuyas funciones defensivas son difícilmente justificables desde los conocimientos poliorcéticos, como se verá más adelante, hasta el extremo de que P. Moret, tras el estudio de las espectaculares torres pentagonales del Castellet de Banyoles de Tivissa -Tarragona-, argumenta que «en fait, le seul rôle politique que l'on puisse attribuer à ces fortifications, ćest, à travers la tâche commune que constitue la construction d'une encente, d'avoir contribué à la structuration de la collectivité.» (1996: 278).

En efecto, a menudo los investigadores de la Poliorcética antigua olvidamos «que el concepto <<ciudad >> en el mundo céltico debió haber sido esencialmente ideológico, como ocurría en Grecia o en Roma, hecho que ha pasado prácticamente inadvertido....Esto hace suponer y explica que la muralla no tuviera una función exclusivamente defensiva, sino que, 
ideológicamente, fuera un símbolo que delimitaba el espacio sacro-político del territorio definido como <<urbano >> comprendido dentro de su recinto, con su correspondiente protección religiosa, estatus y prestigio político, como tan bien se conoce en Roma.» (AlmagroGorbea 1994: 28).

\subsubsection{Del valor pasivo como factor de defensa de la Comunidad}

Evidentemente la intención de destacar estos valores subyacentes de las fortificaciones no permite marginar los papeles estrictamente defensivos desde las ópticas tradicionales, es decir, aquellos encargados de controlar el acceso físico a la Comunidad y, por lo mismo, la salida de ella. De ellos es posible analizar tres variantes: una función elemental, como «contenedor» comunitario; otra ordinaria, como «controlador» del contenido, y una tercera, extraordinario, como «impedimento» extremo del acceso en momentos concretos.

1. Del carácter defensivo básico de las fortificaciones protohistóricas como barreras naturales y disuasorias hablan por si solos los tipos de emplazamientos elegidos, lugares que supeditan las comodidades del hábitat ordinario ante otras condiciones que faciliten el control de los accesos, bien encarrilándolos mediante barreras naturales como barrancos, pendientes o acantilados, bien dando prioridad a los dominios de visibilidad favorables para los habitantes. El estudio realizado por P. Moret sobre 150 emplazamientos iberos arroja una cifra que no da lugar a dudas: sólo el 10,6 \% se localiza en zonas llanas y abiertas (1996: 62) y tal porcentaje, con toda seguridad disminuiría si se analizaran los castros celtíberos o galaicos (por ejemplo: González-Tablas, Arias y Benito 1986). Como se ha analizado profusamente al estudiar ciertos tipos de enclaves muy específicos, esta asociación «emplazamiento/defensa» llega a facilitar verdaderas especializaciones con amplio éxito territorial, como los castros en ladera del Mundo castreño (Carballo 1993: 161-199); los castros costeros sobre penínsulas del Cantábrico tipos «cliff castles» (Camino Mayor 1995: 149 ss.; Cunliffe 1995: 43); los castros de ribero en espigón del Suroeste (Berrocal-Rangel 1992: 226) o los poblados ibéricos «encastillados» en farallones de las serranías del Levante (Moret 1996: 145-149), por citar algunos ejemplos representativos.

A tales ventajas naturales, se suman los valores de la disuasión implicada por muchos de estos emplazamientos y por el mismo carácter masivo o monumental de las murallas (Moret 1996: 286). La importancia de los primeros, aunque lógicamente fuese complementaria, no fue descuidada por las poblaciones protohistóricas, al menos según puede deducirse de la costumbre celta de exponer las cabezas de los enemigos caídos en las entradas de los oppida e incluso de sus propias casas (Aubagnac 1990: 61; Chabot 1983). Y, con tal costumbre, se relacionan algunos conocidos cráneos con clavos hallados en Ullastret, en el Puig Castellar, y en otros yacimientos de Cataluña y Languedoc (Guitart 1975; Pujol 1989; Coignard y Coignard 1991; Moret 1996: 289-290), aún cuando no hayan aparecido cerca de las entradas principales, pues el valor es similar si se ubican en los accesos a una confluencia o a un edificio concreto.

2. El carácter defensivo ordinario relacionado con el control del acceso y la salida se puede suponer desde el momento en el que la fortificación del poblamiento suele acompañar o completar los emplazamientos «en altura». Esta disposición, además de las ventajas básicas referidas en el apartado anterior, está lógicamente relacionada con las posibilidades del control visual de su entorno, ya generalizado como especializado.

La importancia que trasluce del dominio visual en el poblamiento protohistórico peninsular es de tal magnitud que, en relación con el desarrollo elemental de sus fortificaciones, P. 
Moret la considera como el recurso más efectivo y atendido por sus pobladores (1996: 238239; 279-280 y especialmente 262-263). El citado investigador plantea la toma de núcleos ibéricos mediante la sorpresa como el sistema más frecuente en un contexto social como el Peninsular, en el que la guerra se libraba con rápidos ataques o incursiones y no pocos combates individuales, a modo de las «luchas heroicas» de las tradiciones de la Edad del Bronce (por ejemplo: Quesada Sanz 1989: 80; 1997: 652-653 y 2003-b; Carman y Harding 1999; Guilaine y Zammit 2002; Gracia 2003)

Cierto es que estos planteamientos son matizados, e incluso cuestionados, por otros investigadores, especialmente por aquellos que han traducido la presencia de pequeños poblados con torre destacada como puestos vigías o fortines para el control de un territorio fronterizo. Así se planteó para las numerosas torres iberas, en general (Díes Cusí 1991: 177), y para las cercanas a los territorios de Edeta y Kelin, en particular (Puntal dels Llops, Castellet de Bernabé, El Molón de Camporrobles....: Bernabeu et alii, 1987: 137-150; Bonet y Mata 1991: 31 y 2002; Lorrio 2001: 154-155). De igual modo ha sido un argumento utilizado en el estudio de los poblados con torres circulares del Bajo Ebro (Torre Cremada, Torre de Foios, San Cristóbal de Mazaleón....: Sanmartí 1984; Moret 2002-b; Romeo 2002: 179) y los del Alto Guadalquivir tipo «Cazalilla» (Ruiz y Molinos 1989: 128-129). También por nuestra parte, aunque en relación con el control heredado ya en época romana, hemos interpretado la importancia de estas torres destacadas en los castros asturianos partiendo de nuestro estudio sobre el Castiellu de Llagú, donde una espléndida torre redonda de $7 \mathrm{~m}$. de diámetro, dotada de doble sistema de escaleras y de cuerpo de guardia anexo, domina la entrada y las vías de aproximación al castro. Coaña, Pendia, San Chuís y otros poblados con niveles contemporáneos tardíos se caracterizan por torres singulares que refuerzan la importancia del control visual de sus entornos (Berrocal-Rangel et alii 2002: 107). Pero sean atalayas, o un poblamiento ordinario con torres (a veces menos destacadas de los que parecen sus restos: Moret 1996: 159), lo cierto es que ambas interpretaciones valoran en extremo las posibilidades de defensa que aporta un buen dominio visual.

Fuera de este uso, se conocen otros recursos para el control ordinario del acceso, como los fosos y «caminos cubiertos», tallados en paralelo a la escarpada muralla, que encarrilan hacia la entrada principal según se testimonia en el paradigmático poblado del Castellar de Meca (Alfaro y Broncano 1990: 174-176; Alfaro 1991: 147). Otros elementos, como los antemuros frente a las puertas del Castellet de Banyoles o de Ullastret, jugaron una función similar, pues la consistencia y el grosor de estos son tan débiles que difícilmente podrían evitar, o retrasar, un ataque frontal organizado, aunque sí camuflar puntos débiles y defensores (Moret 1996: 130). Algo parecido al uso de las barreras de piedras hincadas a modo de chevaux-de-frise, aunque en este caso hay ejemplos que apuntan hacia soluciones paralelas, poco analizadas hasta el presente.

Así lo deducimos del estudio realizado sobre los castros del SW dotados con estas defensas y, en especial, sobre el Castro de Las Peñas de Aroche -Huelva-, un espectacular asentamiento prerromano con una disposición de piedras hincadas a 200 metros de sus murallas, por otra parte, emplazadas sobre un roquedal inaccesible (Berrocal-Rangel 2003: 222-224 y 227). El poblado responde al tipo IV de nuestra tipología, «en cerro o cima de cadena montañosa», «emplazamientos con cierta importancia estratégica, que muestran posiciones controladoras sobre un paso específico de la citada cadena, mientras que, por otra parte, su independencia en altura les permiten un dominio global de la mayoría de los entornos y una mayor superficie de ocupación. Las evidencias arqueológicas indican que suelen ser emplazamientos de importantes poblados.....» (Berrocal-Rangel 1992: 209).

El cerro, de escarpadas paredes, alcanza la altura máxima de 454 metros s.n.m., más de sesenta sobre el entorno inmediato y más de 30 sobre otras alturas cercanas, aunque es claramente dominado visualmente desde los 482 y 486 metros que presentan las cimas de la 
serranía, distantes unos 250 metros al NW del castro (Lám.: 3). Debió ser precisamente el carácter «marginal» de esta posición de Las Peñas, respecto a los citados cerros superiores y a la serranía que integran, la razón principal para emplazar sobre el camino de aproximación por el lado contrario, al Sureste, el nombrado campo de piedras hincadas. Es importante reseñar que tal campo está distanciado en más de $200 \mathrm{~m}$. del poblado, del que lo separa un cerro menor (398 m.) de paredes inaccesibles. Además todos ellos están rodeados por el Río Chanza que, para salvar la pequeña serranía en su recorrido hacia el Guadiana, tuerce hacia el Noroeste, primero, y hacia el Suroeste, después, de manera que termina rodeando todo el conjunto por el Norte, Oeste y Suroeste. Esta disposición de saco resulta significativa porque, interrumpido el control visual hacia el Este por el citado cerro intermedio de 398 m., el acceso a sus pies es cerrado por un campo de piedras hincadas que cubre esta vaguada, de 75 m. de anchura (Fig.: 9.1). De esta forma se fuerza la aproximación al castro por la vía Sur, la única bien controlada desde sus alturas y rápidamente encajonada entre el río y la serranía. En suma creemos que, en este caso, las piedras hincadas servían para cerrar o interrumpir la aproximación menos controlable, de las dos factibles para acceder al castro ${ }^{16}$.

3. El carácter defensivo extraordinario, concebido para impedir asaltos y sitios, se ha especulado y debatido sobre una base de conocimientos que necesita ser sustancialmente ampliada. Como muestra baste el último debate recogido en esta revista Gladius de la mano de F. Gracia Alonso (2000 y 2001), por una parte, y de P. Moret (2001) y de F. Quesada por otra (2001). En él se afirma y se cuestiona la existencia habitual de sitios y asedios entre los iberos y, de su consecuencia, la disponibilidad de una poliorcética equiparable a cualquiera de las Civilizaciones antiguas del Mediterráneo.

Este debate es, por el momento, la culminación de otro iniciado de forma pautada por R. Pallarés en su conocido artículo «Dos elements de filiació grega.....» (1986), y reafirmado en el compartido con F. Gracia y G. Munilla (1986). Pero en realidad, aunque P. Moret ya se había pronunciado con claras opiniones críticas (p.e. 1996: 113), fue el exhaustivo trabajo presentado por F. Gracia en el X ROMEC (Montpellier 1996), la obra que ha reabierto el tema al intentar el análisis de las fortificaciones ibéricas desde la óptica del uso de la artillería de torsión, estudio apoyado posteriormente por datos concretos sobre los sitios extraídos de los textos greco-latinos (1997 y 2000, respectivamente, más la muy reciente obra La Guerra en la Protohistoria, 2003: 228, 233-234). Las respuestas de Moret y Quesada, en la misma revista Gladius, y otras indirectas pero esclarecedoras en el reciente trabajo de P. Moret dedicado a las fortificaciones complejas iberas (2002), completan un interesante debate del que podemos concluir algunos planteamientos:

1. En general las fuentes escritas grecolatinas no aportan datos sustanciales, ni en cantidad ni en calidad, sobre sitios y asedios de iberos entre sí, o de estos frente a romanos y cartagineses, más allá del reconocido de Sagunto (y sin las «aportaciones» de Silio Itálico: Moret, 1996: 248; Gracia, 2000: 133) y de una veintena de ejemplos, de los que se dispone de citas someras (Moret, 1996: 35-36, tabl. 3; Gracia, 1997: 216-217).

2. Tampoco en el registro arqueológico se constatan armas de asedio complejas, limitadas las pequeñas escorpiones procedentes de Emporion, de los poblados de la Caridad y Azaila, y del Castrejón de Capote -Lám.: 4.3-, estos tres relacionados con las Guerras sertorianas (Cabré, 1944; Vicente Redón et alii, 1997; Berrocal-Rangel, 2003: 200). Por tanto no son testimonios válidos de las armas defensivas de los pueblos his-

16 En el estudio de este yacimiento queremos agradecer las ayudas recibidas del Prof. J. Aurelio Pérez Macías, de la Universidad de Huelva, y del arqueólogo D. Eduardo Romero Bomba. El control visual se realizó mediante el programa Carta Digital de España V.2 del Servicio Geográfico del Ejército con una torre teórica de 20 m. (equivalente a 2 metros reales) y precisión de $5.000 \mathrm{~m}$. 

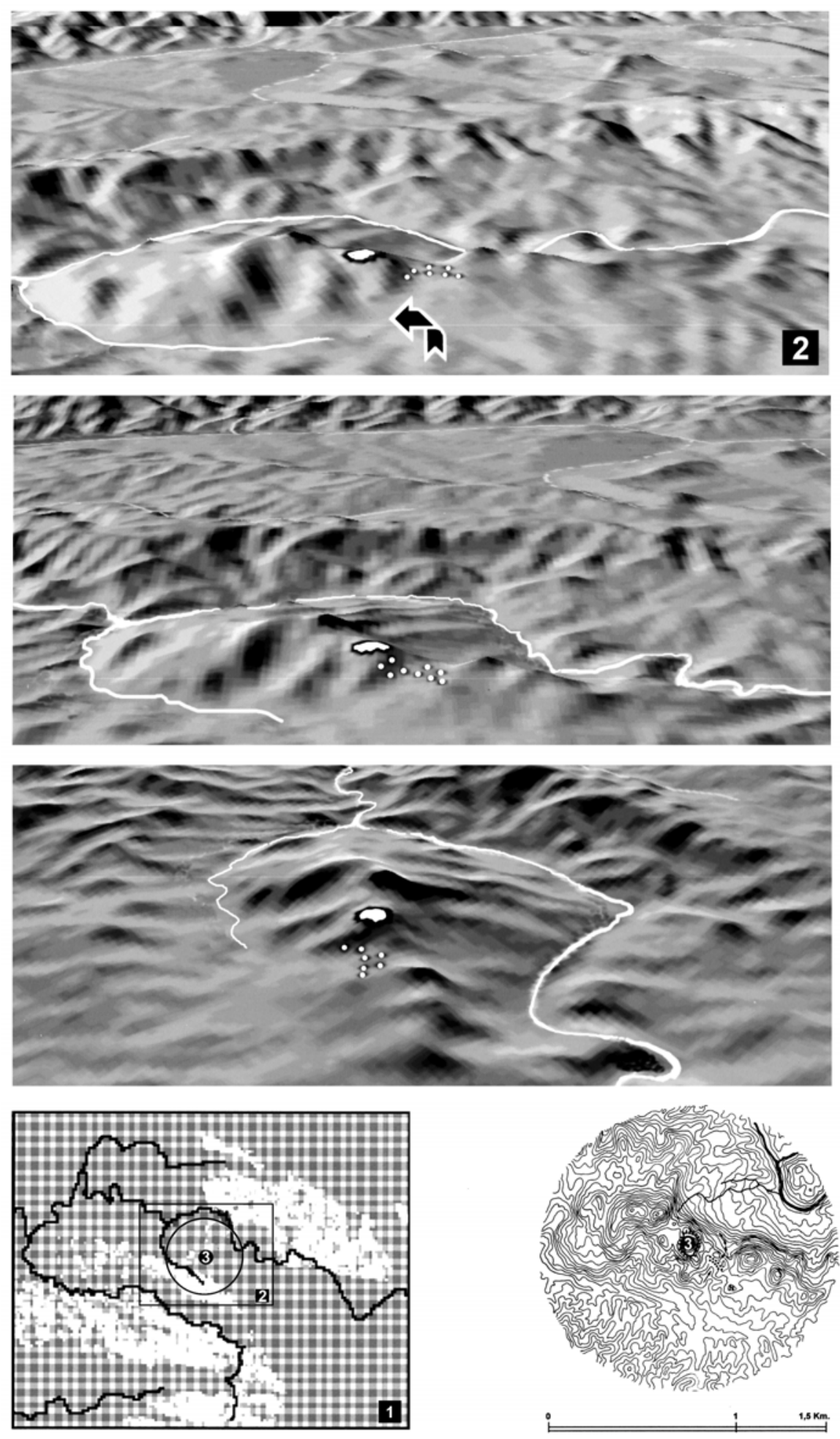

Lámina 3. Emplazamiento del castro de Las Peñas de Aroche $\left(n^{\circ} 3\right)$, con la situación del campo de piedras hincadas $(\mathbf{O})$ y su campo de dominio visual $\left(\mathrm{n}^{\circ} 1\right.$ : espacios en blanco). Reconstrucciones 1 y 2 a partir de la Carta Militar de España V.2. 
panos prerromanos, como deben descartarse las unidades púnicas citadas tras la toma de Cartagena (Tito Livio, Ab Ur. Con., XXVI, 47, 5).

3. Aún así, ni la ausencia de evidencia es un recurso argumental válido como recuerda F. Gracia, ni posiblemente tales ejemplos fueran tan excepcionales como pudiera parecer (p.e. Gracia 2001: 158-159 y 2003: 234). Al menos cada vez se conocen en mayor número pequeños establecimientos coloniales púnicos como Tossal de Manises, cuyas defensas podrían apoyar los impactos de una poliorcética compleja sobre el poblamiento tardío de los iberos.

4. Entre las tácticas y maneras bélicas de los iberos, y de la mayoría de los pueblos prerromanos peninsulares, la contienda «caballeresca o heroica» junto con lucha cerrada de tipo «clánico» y la emboscada debían ser las actuaciones más recurrentes, sin que se constaten ejércitos indígenas formados o se refleje un armamento reglado en las necrópolis más allá de especiales recurrencias de ciertos conjuntos de armas propios de «ejércitos» timocráticos y clientelares (Quesada 1997: 632 ss.; 2002: 39-42 y 49; Ciprés 2002: 138-139; en contra: Gracia 2003: 258). Esto significa que existían unidades preparadas para luchar en orden cerrado, como recientemente ha argumentado F. Quesada (2003-b: 130), pero no eran habituales en la forma de guerrear entre los hispanos como tampoco lo era el sitio o el intento de asedio de un oppidum como recurso ordinario de conquista, más que como consecuencia de un asalto repentino (Quesada 2001: 153). Y aún así siempre con dudas pues recordemos cómo en la Grecia Arcaica no era rentable ni asediar el poblado ni, en muchos casos, defenderlo (Winter 1971: 289-290). En realidad la eficacia militar de un asedio fue cuando menos cuestionable de entrada, especialmente a partir del siglo IV a.C. Por ello todos los tratadistas clásicos aconsejan la toma de una ciudad amurallada mediante la sorpresa o la traición (Polybios, Storiae, 7, 15; Winter 1971: 324).

5. Dentro de la pobreza técnica de los recursos poliorcéticos iberos hay ejemplos que sí implican un profundo conocimiento de las tácticas y estrategias defensivas mediterráneas, al menos desde mediados del siglo IV a.C. y que, por tanto, no es descartable $a$ priori la existencia de asedios o sitios en estos territorios, como plantea F. Gracia (2001: 157-159). El mismo P. Moret viene a coincidir cuando reconoce que Ullastret, Banyoles, Turó de Montgrós, Puigcastellet, La Pícola y la gran torre de Torreparedones son construcciones realizadas con patrones y módulos helenísticos (2002: 189 y 211-212), aunque los materiales y las formas de ejecución varíen en función de la materia prima y la tradición edilicia del lugar. Por ejemplo, a menos que nuevas excavaciones demuestren lo contrario, podría afirmarse que La Pícola es un pequeño establecimiento griego por su concepción urbanística, aunque por el volumen de sus materiales cerámicos sea mayoritariamente ibero.

En suma, es factible defender la existencia de estrategias de defensa complejas a partir del siglo IV a.C. en las costas iberas bajo la influencia directa colonial, si no mucho antes entre los oppida tartésicos, cuando en unos y otros se comprueba el desarrollo de un poblamiento jerarquizado en vías protoestatales: «auténticas ciudades y de numerosos asentamientos menores de funciones muy diversas, incluyendo actividades productivas especializadas....» (Sanmartí y Belarte 2001: 170). Quizá la mejor prueba de esta existencia sea la expansión de ciertos sistemas defensivos como el modelo helenístico integral de defensas avanzadas, denominado «emporitano» y compuesto por berma, foso y antemuro o parapeto (Winter 1971: 275; Adam 1982: 112; Pallarés et alii 1986; Berrocal-Rangel 1995-b: 33; Moret 1996: 214 ss. y 130-131; Gracia 1997: 207-209). Aunque en la docena de ejemplos conocidos, fosos y antemuros están demasiado cercanos a la muralla como para cumplir la función ideal que se les supone, el alejamiento de las máquinas de asedio (Moret 2001: 145), sí 
servirían para evitar trabajos de zapa y mecanismos de impacto directo, como los arietes, además de otras funciones complementarias. Por otra parte, la pragmática naturaleza de la defensa no justificaría la existencia de modelos poliorcéticos complejos asimilables a los griegos y cartagineses más que entre sociedades estatales en plenitud, por lo que es lógico esperar entre iberos o galo-meridionales aparentes deficiencias de adaptación o detalle, ya en relación con la calidad constructiva como con las planimetrías ${ }^{17}$.

Porque de la presencia prerromana de este modelo emporitano, y de otros recursos igualmente complejos, hay pruebas tangibles en el Interior peninsular, especialmente en las zonas de contacto con el Levante como demuestran los yacimientos ibéricos de El Molón (Camporrobles, Valencia-Cuenca: Lorrio 2001) y el Castellar de Meca (Broncano y Alfaro 1990,) o el conocido celtibérico de El Castilviejo de la Guijosa, ya en tierras de Guadalajara, donde se reconoce la única disposición en cremallera de una muralla indígena (Moret 1996: 113-114), reorganizada probablemente en el siglo III a.C. En una disposición parecida se reconocen otras murallas prerromanas de esta comarca, como las de los castros de Castilmontán y, especialmente, del mejor documentado de El Ceremeño (Cerdeño y Martín 1995: 186).

\subsubsection{Del valor latente como representación material de la Comunidad:}

F. Gracia en su artículo «Análisis táctico de las fortificaciones.....» realza la importancia defensiva de estas construcciones por encima de cualquier otra función, pues son «esencial y prioritariamente concebidas para la defensa de los núcleos de población.» (2000: 132). Y realmente, sin olvidar otras complementarias pero no menos importantes como los valores simbólicos y comunitarios (como el mismo Gracia recuerda en sus trabajos, p.e.: 1997: 203204), parece que tal afirmación es evidente por mera lógica interpretativa.

Pero, precisamente, "parecer lo evidente» implica una contradicción en términos que denuncia la existencia de algunas excepciones a lo que es regla: aquellos casos en los que, desde cualquier punto de análisis, las fortificaciones no cumplen los requisitos más elementales para la defensa: se emplazan en lugares batidos desde sus alrededores, no disponen de un dominio visual mínimo del entorno, se sitúan con orientaciones contrarias al defensor (según el conocido principio de «a la derecha del atacante») o se estorban así mismo, creando ángulos muertos innecesarios, en vez de eliminarlos..... Un caso que J. Collis pudo constatar en algunos de los espectaculares oppida de la Edad del Hierro británica, especialmente los localizados en el emblemático territorio de Wessex. Aquí algunas fortificaciones con varias líneas de fosos, parapetos y murallas de tierra y madera, como Scratchbury, aparecen emplazadas en lugares batidos visual y físicamente desde todos los cerros vecinos y por ello, y por los hallazgos habidos en su interior, son interpretados como lugares de especial carga ideológica, quizá destinados a la celebración de ceremonias especiales que podrían ser atendidas por un gran número de asistentes externos a la misma comunidad (Collis 1993: 233; Bewley 1994: 101).

Un caso similar ha sido apuntado para el Castrejón de Capote, castro céltico de la Beturia emplazado en un espigón fluvial aprovechando el horcajo de los pequeños ríos Sillo y Álamo, que confluyen bajo su extremo Occidental (Berrocal-Rangel 1994: 33-34) - (Lám.: 4).

17 En tal sentido, supuestas deficiencias atribuibles a una concepción deficiente, como la irregular orientación de las torres ibéricas, no tiene que ser considerado como defecto sino, por el contrario, podrían reflejar un uso correcto de la defensa, pues tanto Vitrubio (I, VIII) como Philón de Bizancio (A.79, 7-19) desaconsejan construir torres cuadrangulares regularmente dispuestas y alineadas con la cortina muraria, por la capacidad de crear ángulos muertos de difícil cobertura y la escasa resistencia a impactos directos (Adam 1982: 49-60). Por ello apoyan soluciones como las torres no orientadas, sesgadas respecto al lienzo principal, pseudotrapezoidales, poligonales..... , es decir torres de plantas irregulares, aunque esta lectura debe matizarse y no servir de justificación de la impericia. 
El poblado, de 3,2 ha. enmarcadas por los barrancos de estas corrientes, es defendido por una doble línea de murallas que, en su extremo contrario, al Saliente, se configura en forma de fortaleza de $100 \mathrm{~m}$. de longitud y diversas torres, y bastiones. Esta fortaleza disponía en el siglo IV a.C. de un foso de 11 x 4 m., en anchura y profundidad, y una línea de piedras hincadas emplazadas en la berma. Abandonada ésta a mediados del II a. C., el foso fue colmatado y sustituido por un antemuro paralelo a partir de la puerta central, mientras junto a esta se localizaron diversos elementos de una pequeña skorpio (Berrocal-Rangel, 2003-b: 200-201) - Lám.: 4.3. Lo que interesa del caso es que, frente a este cúmulo de construcciones y armamento defensivo, el castro es batido visualmente desde cualquiera de los cerros aledaños, pues está literalmente hundido en el paisaje como en el caso de Scratchbury, lo que parece un sin sentido si sus fortificaciones estuvieran, en verdad, concebidas para la defensa del sitio (en algunos tramos un simple venablo cruza con eficacia las estrechas barranqueras). No es de extrañar, por tanto, el hallazgo de un santuario comunitario en el centro del poblado, que ha sido interpretado como «un contexto de habitación con un lugar específico para realizar solemnemente actos que tienen mucha relación con banquetes y sacrificios rituales y que, en cualquier caso, empiezan a cimentar las bases para encauzar la problemática de la organización social y religiosa de estas poblaciones.» (Lucas Pellicer 1994: 12). Ejemplos similares se van conociendo en diferentes puntos de la Península, como el castro de El Berrocalillo, Cáceres, con sus sólidas defensas dominadas desde todos sus alrededores menos el extremo sobre el río Jerte (Martín Bravo 1999: 12).

Pero, además de estas respuestas simbólicas de naturaleza religiosa y comunitaria, con el valor de ciertas fortificaciones se puede relacionar un papel emblemático, símbolo de prestigio de la comunidad o de la elite dominante. Aunque, como se ha visto, tal valía es inherente a la misma naturaleza fortificada de las murallas, a veces su importancia llega a superar la de otras funciones, incluida la defensiva. Tal es el caso, creemos, de las conocidas torres del Castellet de Banyoles en Tivissa -Tarragona (Pallarés 1984; Pallarés, Gracia y Munilla 1986; Gracia 1997: 213-220; Moret 1996: 217-218; y 2002: 205-206; Müller 1996: 98-100). Conocidas desde el trabajo pionero de R. Pallarés por la singularidad y la espectacularidad del diseño pentagonal de sus plantas, propio de los modelos más avanzados de la Poliorcética helenística, F. Gracia las ha interpretado como un recurso construido contra proyectiles de artillería, con sus vértices frontales y la presencia de la muralla de adobe y tapial que cerraba el acceso, y para cuya conservación se dispuso de una atarjea cubierta bajo la misma puerta. Este muro cumpliría las características de los muros hispanos «a molde» construidos con dos paredes de adobes rellenas de tierra según Plinio, similares a los de doble paramento de piedra y relleno de tierra que, con 20 pasos de grosor, Vegencio recomienda contra la artillería (Gracia 2000: 151).

Sin embargo P. Moret ha observado una serie de deducciones que matizan notablemente la nitidez de esta adscripción: la ausencia de huellas de cajas o vigas en la muralla, que parece más débil en grosor de lo que se supone (pues el muro exterior, paramento para Pallarés, Gracia y Munilla, mide sólo 0,60 m., medida evidentemente insuficiente para cualquier muralla); la convergencia en la proyección del ángulo de ambas torres, impidiendo el control visual eficaz del acceso hasta prácticamente la misma entrada; el mismo ángulo de las torres que, en vez de ser de $90^{\circ}$ como las de Paestum y Akraiphia, es mucho menor (60 ${ }^{\circ}$ ), y la misma disposición en pareja, frente a los casos conocidos en el Mundo griego que son siempre torres aisladas a lo largo de las cortinas murarias (2002: 206).

Aún así hay otras razones que no restan importancia al valor poliorcético de las torres de Tivissa, sobretodo si las consideramos «adaptaciones» locales de modelos helenísticos experimentados. A esta última interpretación contribuye la estructura maciza de los vértices de ambas torres y su disposición pareja, a modo de baterías de artillería helenística como los casos de Goritsa, Heraclea o Pantikapea. En este caso, la solidez de las construcciones de 



Lámina 4. Emplazamiento del Castrejón de Capote (nº 1-4), con la vista de su puerta principal desde el Este $\left(\mathrm{n}^{\circ} 2\right)$ y algunos restos de ballista hallados junto al bastión de la puerta ( $n^{\circ} 3$ : clavos y carrete). Reconstrucción 1 a partir de la Carta Militar de España V.2. 
Tivissa y la agudeza de sus ángulos frontales responderían a las mismas razones del porqué estas baterías se montaban sobre bastiones curvilíneos al exterior, ciertamente más eficaces (Berrocal-Rangel 1994: 52-53; Bakhuizen 1986; Ober 1987; Garlan 1974....). Esta idea ya fue apuntada por P. Moret, aunque sin desarrollarla por considerarlas pequeñas (1996: 218). Pero las torres de Tivissa, con 6,20 x 11,05 metros en anchura y longitud máxima (y de estos, 4,6 m. corresponden a los triángulos macizos), ofrecen el tamaño suficiente para acoger pequeñas skorpioi, precisamente como son los tres casos conocidos de ballistae halladas en la Península, cuya longitud calculamos, grosso modo, en unos 2,4 metros para el ejemplar de Emporion (vide supra).

Con todo, el emplazamiento de un sistema como éste en el interior de la desembocadura del Ebro no deja de parecer una «frivolidad» absoluta desde la óptica defensiva. Porque este tipo de sistema, con antemuros en chicana cruzada frente a las torres-baterías al más puro estilo siracusano, nunca se dispondría en Sicilia o en la Magna Grecia para detener un ataque frontal sobre la puerta principal de una población sino que se colocan lateralmente para cubrir, por la izquierda, el acceso a una puerta secundaria (Tréziny 1993: 45; Berrocal-Rangel 1994: 44-45). Por tanto, desde cualquier punto de vista, funcionalista como sugiere Gracia o simbólico como piensa Moret, las torres del Castellet de Banyoles «doit être interprétée, en fontion de ces données, comme une caractéristique de prestige d’un pouvoir socio-économique.» (Gracia 1997: 220). Y ello tiene su complemento en los materiales hallados en él y en sus entornos, no exentos de fuertes cargas de prestigio.

Si desde la Arqueología defendemos que las fortificaciones llegaron a jugar un importante valor «latente» dentro de los cauces de representación de las comunidades protohistóricas, los textos greco-latinos nos sirven las pruebas de cómo este valor, más que latente, era explícito y reconocido, al menos para los poblados de la Península Ibérica. Es posible traer a colación las citas tantas veces usadas sobre la generalidad fortificada de los hispanos, según recogieron Polybios (en Estrabón, Geog., III, 4, 13) y Tito Livio (cir. 200 a.C.). Este último, como atinadamente observa P. Moret, describe las categorías del poblamiento ibérico encontrado por Escipión en cuatro tipos (urbs, oppidum, castellum y turris), tres de los cuales son fortificaciones y el cuarto, primero de la lista, excepcional en número, una situación que contrasta con la hallada por César siglo y medio después en la Galia, donde, de las tres categorías citadas aquí, sólo la primera y más representativa supone su fortificación (oppidum, vicus y aedificium: Moret 1996: 275) ${ }^{18}$.

En efecto, la imagen de poblaciones encastilladas es tan recurrente y representativa del Mundo ibero, cuando no del celtíbero, vacceo o galaico que, en los diferentes episodios de la conquista de la Península Ibérica, se citan innumerables tomas de castillos y fortalezas como testimonio irrefutable de la sumisión de las poblaciones indígenas. Así ocurre con M. Porcio Catón y la pacificación del Nordeste (195-194 a.C.), con el desmantelamiento ¿exagerado? de 400 fortificaciones iberas —uno die muris omnium dirutis - y la consiguiente prohibición de construir nuevas murallas, prohibición que es, si cabe, más significativa (como lo fue su incumplimiento por la rebelde Segestica, que es tomada con maquinaria de guerra: TitoLivio XXXIV, 17, 11-12 y 20-21; Apiano Iberia, XLI: Martínez Gázquez 1992: 173). Igual pasaría una década después, en la primera guerra celtíbera, con la paz de T. Sempronio Graco (180 - 179 a.C.) y la imposición explícita de no construir nuevas «ciudades» amuralladas (Polibio XXXV, 2), incumplida de nuevo, esta vez por los segedenses, treinta años después, quienes retan el poder romano al decidir edificar la impresionante muralla de Segeda - secaiza II, en Durón de Belmonte (Burillo 1999 y 2003: 213).

18 Ya desde mediados del siglo XX, la Arqueología destacó la importancia del poblamiento abierto en el período de La Tène tardío (véase síntesis e interpretación actual en Collis, Krausz y Guichard, 2000). 


\section{HIPÓTESIS DEL MODELO TEÓRICO}

Sobre los anteriores postulados, nuestra hipótesis se establece en la confirmación o rechazo de las siguientes premisas:

3.1. En términos generales las murallas protohistóricas peninsulares fueron obras realizadas colectivamente por las comunidades a las que dieron «cobijo».

3.2. Las murallas revelan un alto grado de versatilidad adaptativa acorde a las peculiaridades de las comunidades indígenas, pese al origen colonial de la mayoría de los avances poliorcéticos.

3.3. Este grado de adaptación, en combinación con las tradiciones y la capacidad inventiva, produce «modelos» abiertos de poblamiento fortificado.

3.4. Estos modelos, pese a su naturaleza ambivalente, deben manifestar recurrencias que podrían identificar asociaciones étnicas o culturales entre sus comunidades.

\subsection{Las murallas peninsulares como obras colectivas de las comunidades}

Con las premisas desarrolladas es posible afirmar que las defensas protohistóricas peninsulares debieron implicar la mayor participación colectiva, en su construcción y en su uso, salvo escasas excepciones localizadas en las costas mediterráneas en época helenística y en el interior del Guadalquivir del siglo VII a. C. Estas manifestaciones, generalizadas en el poblamiento a partir de los siglos VII y VI a.C., se relacionan con el acaparamiento del poder social por parte de las jefaturas guerreras dentro de los contextos aperturistas derivados de la consolidación de unas relaciones estables y normalizadas a largo alcance.

Aunque para estos momentos la generalidad apoya un desarrollo heroico de la guerra y su supeditación a las jerarquías sociales como contrapartida a la ausencia de contingentes militares profesionales (Quesada 1997 y 2003-b; Romeo 2002: 176), parecen no caber dudas del carácter «democrático» de gran parte de las comunidades hispanas, iberas o célticas, donde las mismas fuentes greco-latinas hacen mención de la importancia de las asambleas y los comicios para regular sus propios jerarcas, régulos incluidos, como se testimonia en la resolución del sitio de Castrum Bergium (Moret 1996: 272-273).

El resultado de esta base popular de la población se traduce en la escasez, cuando no la ausencia, de equipos profesionales de constructores y de una técnica constructiva especializada, elementos que sólo hacen aparición en zonas costeras del Mediterráneo bajo un carácter itinerante y en momentos muy concretos, generalmente cercanos o propios de la Conquista romana. Y por lo mismo no puede extrañar el predominio de aparejos locales de pésima calidad -mampuestos careados por lo general- y sistemas de construcción muy condicionados por los entornos litológicos. Y, también en consecuencia, no extraña que las escasas aproximaciones a la fuerza de trabajo necesaria para edificar las fortificaciones peninsulares arrojen cifras de operarios y períodos de construcción relativamente o categóricamente bajos, factibles para contextos comunitarios como los descritos (Sanmartí y Santacana 1990: 333; Py 1990: 166; Almagro-Gorbea, en Almagro-Gorbea y Gran-Aymerich 1991: 265-266; Moret 1996: 270; Gasco 2000: 190-191). Las excepciones existieron, implicando desde algunas fortificaciones complejas iberas (Ullastret como paradigma, pero también el Turó del Montgrós, Sagunto, La Serreta, Puente Tablas, Torreparedones, .....) a la presencia de ejércitos mercenarios celtíberos en Turdetania, como únicas fuerzas profesionales reconocidas por el momento (Blázquez 1987-1989; Blázquez y García Gelabert 1991; Quesada 1994.....). Pero la generalidad patente es una poliorcética poco desarrollada técnica y funcionalmente, sin 
duda porque el carácter social de las poblaciones hispanas carece de los mecanismos estatales que se traducen en entidades militares profesionales y organizadas a modo de verdaderos ejércitos, y en una respuesta edilicia que configure las fortificaciones en recursos capaces de resistir los asedios prolongados procedentes de tales ejércitos.

En consecuencia, con las salvedades citadas, la capacidad constructiva de las poblaciones protohistóricas peninsulares fue muy limitada en comparación con otros territorios mediterráneos, estando más cercana en sus principios básicos a la conocida en los ámbitos atlánticos y centroeuropeos.

\subsection{Los elementos defensivos, reflejos de un fuerte grado de versatilidad adaptable.}

De los ejemplos analizados en el segundo postulado se deduce un fuerte grado de adaptabilidad y convergencia en técnicas y conceptos defensivos de origen extrapeninsular, grado que responde a las diferentes características sociales, económicas, culturales y medioambientales de las diversas comunidades indígenas. La evolución independiente de las ideas mediterráneas o autóctonas, y de los elementos técnicos aplicados, es conjeturable desde el análisis detallado de las documentaciones originarias y de los contextos de aparición de tales elementos y conceptos. Este análisis, que ha de ser realizado con el detalle y la envergadura de conocimientos suficiente como demuestra P. Moret para el ámbito ibérico, puede pergeñarse en el estudio de los elementos-traza seleccionados:

Los paramentos múltiples, las obras subrectangulares de ángulos achaflanados, el uso del adobe y los fosos perimetrales se conocen desde el Calcolítico peninsular y pueden ser rastreados, en diferente grado, a lo largo de las Edades del Bronce hasta su irrupción en el Bronce Final - Hierro Antiguo de la Meseta y del Norte peninsular (p.e. en Sanchorreja, Arbeca, Soto....). Pueden ser, por tanto, origen de los elementos constructivos específicos posteriores, aunque a veces estos sean revestidos de un carácter novedoso, difundido o interpretado como solución convergente con la importación de las murallas «de cajones» fenicias de las primeras colonias del Mediodía peninsular. Aún así en todos los casos la aparición de estos elementos dentro de la poliorcética protohistórica va de la mano de los avances técnicos derivados de la consolidación de relaciones estables con el Mediterráneo al menos desde finales del siglo VII a.C. Sólo los campos de piedras hincadas y los fosos perimetrales apuntan otras relaciones asimilables, convergentes con el resto del Arco atlántico europeo.

Como consecuencia directa de estas relaciones las torres y obras cuadrangulares, los aparejos de sillares y sillarejos, y gran parte de las estructuras llamadas de «cajones», muestran un origen fenicio claro, aunque rápidamente adquirirán un desarrollo diverso y claramente local. Así las primeras presentarán diseños propios, adaptados e incorporados en forma de torres y bastiones trapezoidales en los grandes oppida turdetanos del siglo VI a.C. Y, el uso de sillares o de cajones se difundirá desde diversas trayectorias de la mano del impulso poliorcético helenístico, propiciado desde el golfo de León y la Costa Blanca a partir del siglo IV a. C. De igual manera las murallas de casamatas, el aparejo ciclópeo y los fosos con antemuros, aunque puedan presentar remotos precedentes orientales, son derivaciones directas del fenómeno helenístico y de la presencia/influencia cartaginesa (gran torre de Torreparedones 3), griega (La Pícola, Ullastret, Turó del Montgrós,.....) e itálica (Castellet de Banyoles).

Los campos de piedras hincadas, y en cierto sentido los fosos perimetrales, son elementos sin precedentes anteriores al Bronce Final que proliferan inusitadamente a partir del siglo VII en el Nordeste, y del VI en el Suroeste y en la Meseta Central. Se mantendrán hasta el siglo I d. C. como soluciones puntuales entre celtíberos, célticos, astures y galaicos, quizá favorecidos como respuestas peninsulares a los sistemas de defensa avanzada romano-republicanos, los lilia usados por César, pero su memoria sólo se justifica porque tuvieran un uso ordinario como 
elementos organizadores del espacio extramuros, compaginados con paralelos de madera que no se han conservado. Se observa en ello, por tanto, una convergencia con los sistemas atlánticos y continentales que podrían verse reforzados por el reconocimiento de murallas de piedra y trabazón de madera en la cornisa cantábrica y el Suroeste peninsular.

En suma, el análisis aproximado de estos elementos defensivos, y de los conceptos que implican, demuestra la importancia de las tradiciones constructivas peninsulares en todos los ámbitos culturales y elementos estructurales, unas tradiciones que contrastan por su simplicidad técnica frente a la complejidad de las trayectorias coloniales mediterráneas, y que admiten y adaptan los prestamos de esta procedencia de manera desigual. De ellos, la construcción de obras cuadrangulares con esquinas encadenadas fue la aportación más trascendente, acaecida durante el siglo VII y manifestada masivamente en la zona mediterránea de la Península a lo largo del siglo VI a. C., mientras en el interior meseteño y el suroeste atlántico no se generaliza parcialmente hasta finales del IV a.C. y, en el Noroeste, del I d. C. Otras aportaciones, en la forma de esquemas complejos o especializados (casamatas, cremalleras, fosos con antemuros, puertas cubiertas.....), se documentan sólo en ambientes de penetración costera fundamentalmente desde el Mediterráneo, aunque también desde el atlántico, dispersando sus ejemplos en el hinterland interior hasta ser tan «singulares» y adaptados que, a menudo, son incomprensibles desde una óptica exclusivamente defensiva (como el Castilviejo de la Guijosa -Gualadajara-, pese a su buen diseño).

La Meseta, y especialmente el Occidente y el Norte atlántico, desarrollan sistemas básicamente indígenas hasta alcanzar una complejidad notable que manifiesta variaciones propias de distintos ambientes culturales y ecológicos, y converge con las fortificaciones centroeuropeas y atlánticas contemporáneas en sus elementos esenciales como los fosos concéntricos, las piedras hincadas y las estructuras de piedra, madera e incluso adobe (Fosos de Bayona -Cuenca-, Valdeavellano -Soria-, Pintia y Soto -Valladolid-, Monte Bernorio Palencia-, La Campa Torres y Chao Samartín -Asturias-, Torroso -Pontevedra-.....). Se reafirma, así, la naturaleza singular y la antigüedad de la celticidad peninsular manifestada en otras producciones materiales (p.e. las espadas de antenas atrofiadas: Lorrio 1994: 158) y rasgos ideológicos (p.e. las representaciones de cabezas cortadas: Almagro-Gorbea 2003: 155), sin duda difundidos en gran parte gracias al corredor galo meridional cuyas huellas en Cataluña y el Valle del Ebro son, cada día, más claras a lo largo de todo el I Milenio a.n.e. (Almagro-Gorbea 2003: 151-152; Moret 1991: 39; Arcelin y Dedet 1985: 22). Es importante anotar que los fosos de sección en «V», una de las escasas prestaciones romanas que se incorporan a estos sistemas en el NW., ya tenían precedentes conceptuales en ellos, posible causa de su proliferación posterior (Carvalhelhos, San Cibrán de Lás, Monte Trega,......).

Por tanto, como tercera conclusión, afirmamos que la capacidad de adaptación e inventiva peninsular, junto con la base participativa comunitaria implícita, fueron bases suficientes para favorecer la gestación de pautas defensivas a modo de «modelos» del poblamiento fortificado, pautas con cierta incidencia territorial, aunque siempre con rasgos y límites flexibles.

3.3. Adaptabilidad, tradición e inventiva, ingredientes de los modelos fortificados peninsulares

Es lógico que la conjunción de estos componentes favoreciera la génesis de una variada gama de soluciones que, en algunos casos, se consolidarán como verdaderos modelos, sistemas fortificados que se repiten en un territorio y un período concreto según normas estratégicas y elementos técnicos más o menos reiterados. En tal sentido, a modo de un análisis preliminar, es posible distinguir los que proponemos a continuación: 
3.3.1. El modelo defensivo meridional o de los oppida del Alto Guadalquivir (Ss. VI a C. - III a. C. ), con ejemplos paradigmáticos como Torreparedones, Giribaile o Puente Tablas, pero también casos aparentemente distanciados y más tardíos que van a significar la verdadera entidad territorial de este modelo: el Alto de Benimaquía (Alicante); La Bienvenida - Sisapo (Ciudad Real), o incluso las torres redondas del oppidum de Mértola (Gómez Bellard 1993: 18; Fernández Ochoa 1992: 24; Hourcade, López y Labarthe 2003) - (Fig.: 9). Se trata del esquema fortificado de los principales poblados indígenas del Sur peninsular, cuyos emplazamientos centrales y materiales arqueológicos permiten considerarlos como verdaderos oppida, y cuya fortificación parte de finales del siglo VIII a. C. bajo la influencia de las «murallas ciudadanas» fenicias, cuando se gestan las primeras características del modelo (Ruiz y Molinos 1993: 113 ss.; Moret 1996: 510; Escacena y Fernández Troncoso 2002).

Sobre los valles béticos con campiñas bien regadas y de alta producción agrícola o comercial, aprovechan cerros amesetados o alturas destacadas que fortifican con líneas de murallas sencillas y extensas. El emplazamiento de Puente Tablas puede considerarse representativo de estos oppida, que no explotan al máximo las disponibilidades defensivas de sus entornos sino que optan por posiciones más accesibles a cambio de otras ventajas. Así el mismo Puente Tablas no se emplaza en la altura dominante del lugar, sino en un cerro menor, situado en el acceso inmediato por el sur y sin las condiciones ventajosas que le proporciona, a ésta, la confluencia de un arroyo con el río Guadalbullón. Los trazados amurallados son lineales, bien rectilíneos o curvilíneos, y a menudo rompen con vaguadas y curvas de nivel para seguir las divisorias de aguas de los distintos cerros ocupados. Por ello, esta planimetría no suele contemplar ni fosos ni dobles recintos, de no considerar alguna acrópolis desconocida como la arx de Ilurci (Moret 1996: 131). Sus aparejos son muy característicos por la buena calidad comparativa que presentan, con sillarejos pequeños, a veces cuasi regulares, de clara ascendencia fenicia (p.e. Doña Blanca), aunque lo habitual son los mampuestos careados y calzados con piedras menores regularmente establecidas. Lo masivo de estas cortinas amuralladas obliga a usar estructuras de refuerzo, como paramentos adosados exteriores, bastiones y, en el caso de Puente Tablas, se refuerzan con estructuras de cajones (Ruiz Rodríguez et alii 1991: 115).

El buen conocimiento de esta muralla sirve como paradigma de las singularidades constructivas del modelo: «El muro se levanta a plomada, que, con otro paralelo, se rellena de piedras y tierra. Este lienzo se construye con elementos de mediano tamaño y dispuesto en seco con calzos de piedra pequeña y tierra. Sin embargo, este muro no queda visible al exterior porque sobre él se construye una nueva cara a plomada. Cada ciertos tramos se disponen bastiones-contrafuertes cuadrangulares con la misma técnica de construcción ya advertida para el lienzo; por último, toda la superficie exterior del muro se revoca con yeso. En el exterior, se advierten los restos de adobe que debían disponerse sobre el muro de piedra, que..... en fases posteriores (siglo VI a.n.e.) se remodela construyendo una base más ancha sobre la que se elevaría el paramento de adobe, con la misma técnica constructiva. En Tejada (Fernández Jurado 1987) se observa un sistema muy semejante de fabricación con dos paredes rellenas de piedra y tierra sobre las que se apoyan enormes contrafuertes rectangulares y circulares con la misma técnica de amontonamientos de piedra.» (Ruiz y Molinos 1993: 202).

Con estas estructuras masivas es comprensible que las obras de flanqueo se desarrollen a partir del concepto funcional de contrafuertes exteriores. Por ello se disponen en forma de torres o bastiones macizos de planta trapezoidal, con los flancos entrantes hacia el interior, un sistema característico de estas fortificaciones cuyo origen parece ser autóctono, aunque inspirado en las construcciones fenicias (p.e. en Ciasca 2000; Díes Cusí 2001: 83 ss. y esp. 96; Schubart 2002, etc.). Este es el rasgo más característico del modelo, incluyendo el emplazamiento más o menos regular de dichas torres-contrafuertes, habitualmente desorientadas respecto al lienzo amurallado, lo que redunda en el trazado variable de éste, ya rectilíneo 


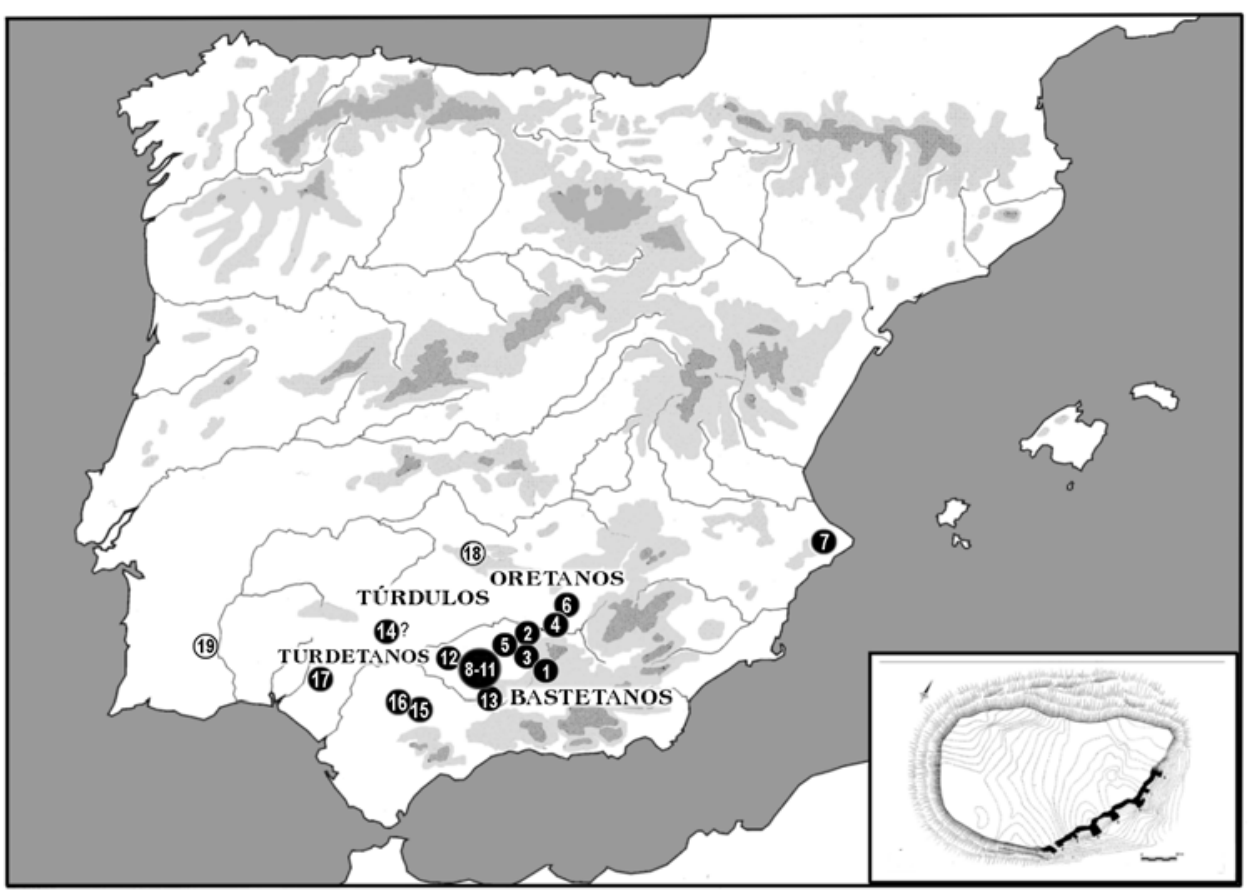

\begin{tabular}{|c|c|c|c|c|c|c|c|c|}
\hline $\mathbf{N}^{\circ}$ & POBLADO & EMPLAZAMIENTO & TRAZADO & APAREJO & CORTINA & FLANQUEOS & AVANZADAS & DATACIÓN \\
\hline 1 & Puente Tablas 2 y 3 (Jaein) & cerro sobre valle & curvilineo & |adobes y piedra & paramentos mút| & trapezoidales macizos & $\ldots$ & Ss. VI-IVa.C \\
\hline 2 & La Coronilla de Cazalilla (Jaén) & cerro aislado & curvilineo & mampuestos & paramentos múlt & trapezoidal macizo & $\ldots$ & Siglo VI a.C. \\
\hline 3 & Atalayuelas Fuente $\operatorname{del} \operatorname{Rer}(\Omega)$ & cerro piedemonte & $\ldots$ & mampuestos irr. & paramentos mútt & trapezoidal? macizo & $\ldots$ & Ss. VI.V a.c. \\
\hline $4 ?$ & Cástulo (Jaén) & cerro sobre valle & lineal & mampuestos gr. & 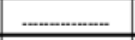 & cuadrangulares menor & $\ldots$ & Ss. III a.C... \\
\hline $5 ?$ & Los Alcores de Porcuna (Jaén) & cerro en espigón & rectlineo & $\ldots$ & $\ldots$ & $\ldots$ & $\ldots$ & Ss. VIIVaC \\
\hline 6 & Ginbaile (Jaén) & cerro piedemonte & sinuoso & mampuestos pe. & \multirow{2}{*}{\multicolumn{2}{|c|}{\begin{tabular}{|l|} 
paramentos mült cuadrangulares \\
paramentos mülit trapezoidales macizos \\
\end{tabular}}} & $\ldots$ & Ss. VI-IV aC. \\
\hline 7 & Alt de Benimaquia (Alicante) & cerro destacado & rectilineo & mampuestos ir. & & & $\ldots$ & Ss. VI-VaC. \\
\hline $8 ?$ & Cerro Minguillar (Córdoba) & cerro sobre valle & lineal? & ciclópeo & simple & cuadrangulares macizos & s -......... & Ss. IV-III aC. \\
\hline 9 & Torre Morana (Córdoba) & cerro destacado & lineal & mampuestos pe. & ........ & cuadrangulares & ․․….. & Ss. IV..... \\
\hline 10 & Torreparedones 2-3 (Córdoba) & cerro destacado & lineal & mampuestos gr. & \multicolumn{2}{|c|}{ paramentos múltc cuadrangulares macizos } & S & Ss. VI-III aC. \\
\hline 11 ? & Las Cabezas Fuerte Tojar (CO) & cerro destacado & lineal & ciclópeo & ........ & cuadrangulares & $\ldots$ & Ss. IV aC. \\
\hline 12 & El Higuerón (Córdoba) & cerro piedemonte & lineal & ciclopeo & en terraza & cuadrangulares & $\ldots$ & Ss. IV aC... \\
\hline 13 & Camino del Tarajal (Córdoba) & cerro piedemonte & \begin{tabular}{|l|l} 
lineal \\
\end{tabular} & mampuestos ir. & paramentos múlt & cuadrangulares macizos & $-\cdots$ & Ss. VIIV aC. \\
\hline $14 ?$ & Setefilla 1-2 (Sevilla) & cerro en espolon & lineal & mampuestos ir. & paramentos múlt & curvilineas? & $\ldots$ & Ss.VIII-IV aC \\
\hline 15 & Camorras (Sevila) & cerro destacado & curvilinea & $\ldots$ & $\ldots$ & cuadrangulares macizos & 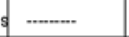 & Ss. II-I a.C. \\
\hline 16 & Pajares de Osuna (Sevilla) & |llanura aluvial & lineal & $\ldots$ & $\ldots$ & cuadrangulares & torres exentas & Ss. III a.C. \\
\hline 17 & Tejada la Vieja 2 (Hueva) & cerro piedemonte & sinuoso & mampuestos ir. & paramentos muilt & trapezoidales macizos & $\ldots-$. & Ss.VI-VaC. \\
\hline 18 & La Bienvenida (Ciudad Real) & cerro destacado & curvilineo & sillarejos & muro simple & curvilineas macizas & & Ss.IV-III aC. \\
\hline 19 & Mértola (Baixo Alertejo) & escarpe fluvial & lineal & sillarejos & muro simple & curvilineos macizos & & Ss.IV-III aC. \\
\hline & & & & & & & & \\
\hline & & & & & & & & \\
\hline & & & & & & & & \\
\hline & & & & & & & & \\
\hline & & & & & & & & \\
\hline & & & & & & & & \\
\hline
\end{tabular}

Figura 9: Distribución de los poblados fortificados según el «modelo meridional» y algunos yacimientos representativos. 


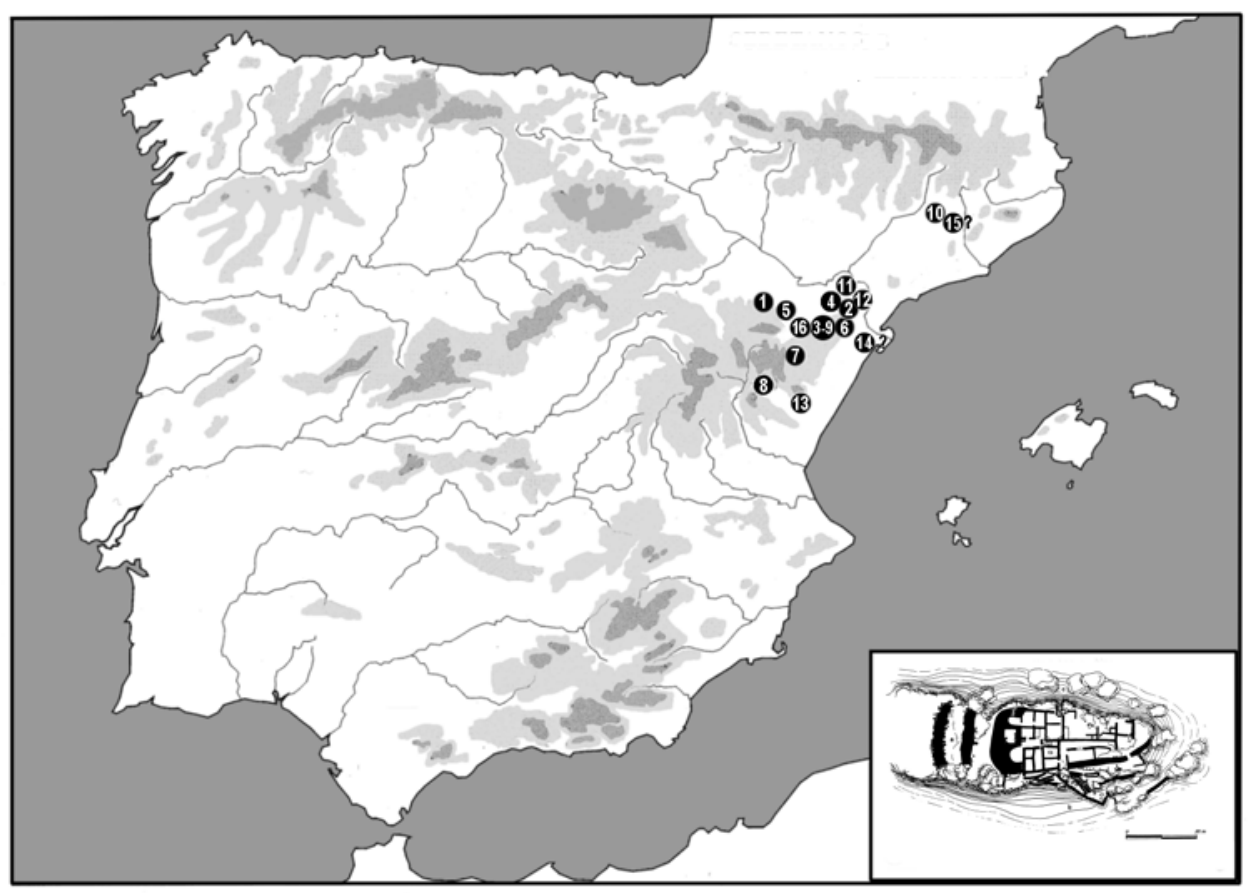

\begin{tabular}{|c|c|c|c|c|c|c|c|c|}
\hline $\mathbf{N}^{\circ}$ & POBLADO & EMPLAZAMIENTO & TRAZADO & APAREJO & CORTINA & FLANQUEOS & AVANZADAS & DATACIÓN \\
\hline 1 & S. Pedro de Oliete (Teruel) & Lescarpe o farallón & sinuoso & $\mid$ megalitico & muro simple & \multicolumn{2}{|c|}{ torre redonda huecal foso frente puerta } & Ss. III-I ac. \\
\hline 2 & S. Antonio 2 Calaceite (Teruel) & farallón & lineal & mampost ireg & muro simple & \multicolumn{2}{|c|}{ lorre curvinnea hueca foso trente puerta } & Ss.IV-I a.C. \\
\hline 3 & Torre Cremada (Teruel) & escarpe & $\ldots$ & sillares trapez. & muro simple & \multicolumn{2}{|c|}{ torre redonda hueca } & Ss. II-I a.C. \\
\hline 4 & S.Cristobal Mazaleón (Teruel) & espolón & Ineal & mampost ireg. & muro simple & \multirow{2}{*}{\multicolumn{2}{|c|}{$\begin{array}{l}\text { forre curvilinea huece } \\
\text { t. forre curvilinea hueca foso frente puerta }\end{array}$}} & Ss.VII-VI aC \\
\hline 5 & La Guardia de Alcorsia (Teruel) & 1) farallón & irregular & mampost irreg. & paramento muilt. & & & Ss.IV-I a.C. \\
\hline 6 & Els Castellans Cretas (Teruel) & farallon en cresta & lineal & mampost irreg. & paramentos múlt. & \multicolumn{2}{|c|}{ It torre curvilnea hueczfosos frente puerta } & Ss.VIII a.C. \\
\hline 7 & Castellar Mas Dalmau (Teruel) & farallón & $-\ldots+\ldots$ & $-\ldots+\ldots$ & $\ldots+\ldots$ & torre redonda? & $-\ldots+\ldots$ & Ss. IV a.C... \\
\hline 8 & Hiladas Bajas I (Teruel) & espolón & lineal & ............. & $\ldots$ & torre? & foso frente puerta & Ss.III- a.C. \\
\hline 9 ? & Tossal Montañés (Teruel) & cerro sobre valle & lineal? & mampost irreg. & $\mathrm{x}$ & torre hueca aislada & $-1-\ldots$ & S. VI a.C. \\
\hline 10 & Castelvell (Lleida) & colina piedemonte & sinuoso & sillarejo & muro simple & torre? curvinea mur. & …… & Ss.IV-II a.C. \\
\hline 11 & Tossal del Moro (Tarragona) & cerro sobre valle & Ineal & mampost. irreg. & muro simple & torre curvilinea & \begin{tabular}{|l|} 
foso frente a torre \\
\end{tabular} & Siglo V a.C. \\
\hline $12 ?$ & Coll del Moro 2 (Tarragona) & escarpe o farallón & lineal? & mampost irreg. & muro simple & torre curvinnea maci. & 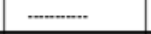 & Siglo IV a.C. \\
\hline 13 & Torre de Foios (Castellión) & cerro destacado & $?$ & sillarejos & muro simple & torre ovoide hueca & $-\ldots$ & Siglo IV a.C.... \\
\hline $14 ?$ & Puig la Nau (Tarragona) & escarpe & rectlineo & mampost adobe & paramento mútitip. & torre ovoide maciza & antemuro frente $\mathrm{p}$. & Siglo IVAll aC. \\
\hline $15 ?$ & Aseresa/E Vilaró (Leida) & cerro piedemonte & curvilineo & mampost. ireg. & muro simple & torre redonda? & & Siglo VII-Vl ac \\
\hline 16 & Palao de Alcañiz (Teruel) & cerro sobre valle & sinuoso & \multicolumn{2}{|c|}{ mampost. irreg. muro simple } & torre redonda & \multicolumn{2}{|c|}{ foso frente a torre Siglo VI a.C. } \\
\hline & & & & & & & & \\
\hline & & & & & & & & \\
\hline & & & & & & & & \\
\hline & & & & & & & & \\
\hline & & & & & & & & \\
\hline & & & & & & & & \\
\hline & & & & & & & & \\
\hline & & & & & & & & \\
\hline & & & & & & & & \\
\hline
\end{tabular}

Figura 10: Distribución de los poblados fortificados según el «modelo de casastorres del Bajo Ebro» y algunos de sus yacimientos representativos. 
como cóncavo o convexo. Pero tales irregularidades, tanto de las torres como del trazado murario entre ellas, son coherentes desde la óptica defensiva pues sirven para aumentar la variedad de los ángulos muertos, dificultando con ello su localización por parte del enemigo (Adam 1982: 39).

En suma se trata de un modelo cuya simplicidad puede provocar erróneas deducciones pues conceptualmente responde a planteamientos poliorcéticos complejos que se permiten, por ejemplo, desaprovechar algunas facilidades naturales para la defensa. La sencillez y la escasez de sus recursos deberían ser comprendidas más como consecuencia de una sociedad con menores imperativos bélicos que la manifestada varios siglos después, cuando la mera monumentalidad de las murallas masivas sería claramente insuficiente ante ejércitos púnicos y romanos. Así puede observarse que el proceso de complejidad creciente implicó la generalización del poblamiento fortificado a partir del siglo VI a. C., primero con asentamientos específicos como las llamadas «torres-atalaya tipo Cazalilla» en Jaén (Ruiz y Molinos 1993: 116 y 258) y, posteriormente, con el abandono de éstas y otros poblados en favor de la potenciación de los oppida, especialmente evidente a partir del siglo III a. C. Entonces el modelo se transforma y el proceso se refuerza con la aparición de diversos elementos y recursos helenísticos, tanto en los grandes poblados como en las atalayas y asentamientos dependientes, reflejos de las influencias o de las presencias púnicas. Así se considera la gran torre sícula de Torreparedones 3, el uso de aparejos ciclópeos como el reconocido en El Higuerón, o de paramentos complejos, como el spicatum sobre base de piedras planas de Puente Tablas (Ruiz y Molinos 1993: 202). Con estos y otros añadidos el modelo meridional desaparece, diversificado hasta su desintegración en Época Romana, desarrollando variables como la disminución del tamaño y la transformación de las plantas de sus torres, ahora en esquemas rectangulares o curvilíneos como se observa en el mismo Plaza de Armas de Puente Tablas, o en los casos periféricos ya comentados de La Bienvenida - Sisapo (Ciudad Real) y Mértola.

3.3.2. Los modelos defensivos ibéricos del Bajo Ebro -Guadalope, Matarraña, Algás(ss. VI a.C. y III a.C.) manifiestan una cierta variedad incluso en un mismo contexto cultural, con hábitats de mayor tamaño como Azaila y otros pequeños como Torre Cremada -Teruel- o Torre de Foios -Castellón-, que responden a diferentes pautas fortificadas aunque comparten elementos y soluciones defensivas específicas. Esta homogeneidad se vería reforzada de confirmarse las interpretaciones que consideran algunos de estos pequeños poblados como verdaderas acrópolis de asentamientos mucho mayores, siguiendo el modelo identificado en Azaila (p.e. San Pedro de Oliete, Torre Cremada y el Palao de Alcañiz: Moret y Benavente 2000: 329.; y Benavente, Marco y Moret 2003: 232). Sobre elevaciones destacadas en los valles fluviales, los poblados más grandes se extienden por los terrenos llanos y aluviales circundantes hasta alcanzar una decena de hectáreas (Asensio 1995: 409). Reflejan la necesidad de varias líneas defensivas, constatándose al menos una en torno al cerro principal, circunvalando la acrópolis, y otra más extensa en el llano, apoyada en fosos y otros elementos (Romeo 2002: 178). Los aparejos no manifiestan influencias externas antes de la llegada de los romanos, siendo de mampuestos colocados a seco o, en el mejor de los casos, con talla centrípeta careada.

Este tipo de asentamiento se define más por sus rasgos planimétricos y conceptuales que por la singularidad de sus defensas, a diferencia de un modelo «menor», caracterizado por pequeñas alturas torreadas que, sin duda por la importancia comparativa de éstas en el conjunto construido, pueden ser calificadas de verdaderos «caseríos-torres» (Fig.: 10). Así, este otro modelo es identificado por la ocupación de farallones o escarpes, a veces en crestas de serranías; por el uso de superficies pequeñas (0,2/0,3 ha.), y por la importancia de una torre hueca de planta curva, cerrada o no, que suele destacar en un extremo de la línea amurallada, o aparecer exenta en su interior. 
En primera instancia, la importancia y la singularidad de este rasgo se revela porque las torres de planta «redonda» son escasas en la Península y, sin embargo, en esta comarca se conocen desde el Hierro Antiguo con ejemplos como Tossal Montañés y el Palao de Alcañiz (Moret 2001: 98). Y, en segunda, porque durante el Hierro Pleno se integran en esquemas de poblamiento más desarrollado, remarcando su singularidad mediante el emplazamiento frente a la puerta única o principal del poblado, a la que defiende generalmente junto con uno o dos fosos. Su construcción, a diferencia de la escasa entidad de la cortina muraria, es realizada con gruesas paredes de mampostería y alzado troncocónico como se observa en S. Cristóbal de Mazaleón, S. Pedro de Oliete, Calaceite, Torre Cremada y El Castellans de Creta, todos ellos ejemplos en la provincia de Teruel; o como Tossal del Moro, en la de Tarragona; y Torre de Foios en Castellón (Moret 1996: 106; Moret y Benavente 2000: 336). Un paralelo formal muy cercano, cuya función final como almacén de ánforas parece tener poca relación con estas torres, fue identificado como «recinto A» en Aldovesta -Lleida-. En realidad es posible que su semejanza en planta sea sólo aparente pues se cubría mediante aproximación de hiladas según conjeturaron sus excavadores, quienes descartaron un uso previo defensivo dado la escasa idoneidad del emplazamiento para ello (Mascort et alii 1991: 23). Pero es incuestionable que su forma y el grosor de sus muros contrastan notablemente con el resto de construcciones del poblado y se explican con evidente dificultad.

Cierto es que el modelo comparte disposiciones genéricas comunes con otros poblados cercanos, bien con una sola torre cuadrangular frente a la entrada (Puntals dels Llops -Valencia-) o con dos (Puig de la Misericordia -Castellón-), pero no creemos que tales similitudes resten definición a la peculiaridad de este modelo, que tampoco tiene relación directa con los poblados de «espacio o calle central» como suponían O. Arteaga, J. Padró y E. Sanmartín (1990: 156), pues los casos de Torre Cremada o San Pedro de Oliete lo caracterizan como un modelo de casa-torre independiente de otros urbanísticos más genéricos. Incluso se relaciona con una comarca natural muy concreta definida por los afluentes meridionales del Ebro del Guadalope y del MatarrañaAlgás ${ }^{19}$. En general este modelo se considera dentro de una poliorcética plenamente indígena, compleja por los recursos añadidos pero conceptualmente mucho más primitiva que la anterior. Es fruto de viejas tradiciones constructivas que sólo comenzarán a admitir elementos mediterráneos a partir del siglo III y sobre todo del II a.C., desarrollando entonces la complejidad de sus características con el uso de cajones en las murallas y de poternas bajo la presión defensiva de las incursiones cartaginesas y romanas (Romeo 2002: 168).

3.3.3. El modelo defensivo de las Serranías Orientales de la Meseta Norte - Alto Duero (Ss. VI a.C. - III a.C.) se encuentra representado por un sistema de pequeños poblados de la Primera Edad del Hierro, personalizado por los castros de la Serranía Soriana (p.e. Castilfrío de la Sierra, Valdeavellano de Tera, Zarranzano....) - (Fig.: 11). En momentos avanzados, a partir del siglo IV a. C., algunas de las características de este modelo comienzan a reconocerse con mayor dispersión en los valles altos del Tajo y Duero, ya con modificaciones y aplicaciones concretas que demuestran su modernidad y su pérdida de cohesión (Oceanilla, Castilviejo de la Guijosa, Ceremeño.....) - (Romero 1984 y 1991; García Huerta 1990; Cerdeño et alii, 1995: 170-172).

Todos estos poblados muestran las preferencias de sus habitantes por emplazamientos en espolones y farallones, con condiciones climáticas extremas y una relación con el entorno basada en la explotación estacional de los recursos ganaderos y del control de paso (Cerro Hontalvilla Soria-, Alto de Solana de Sagides -Soria-). Para ello optan por recintos pequeños, de trazados muy sencillos e incompletos — asociados a tramos inaccesibles sin amurallar-, y fuertemente adaptados a la orografía, como es propio de refugios que, quizá, se ocupaban sólo temporalmen-

19 Aunque se puedan reconocer ejemplos apartados al Norte del Ebro, como en los ilerdenses Castelvell y posiblemente en Aseresa, y al Sur, y con mayores dudas, en el castellonense de Puig de la Nau. 


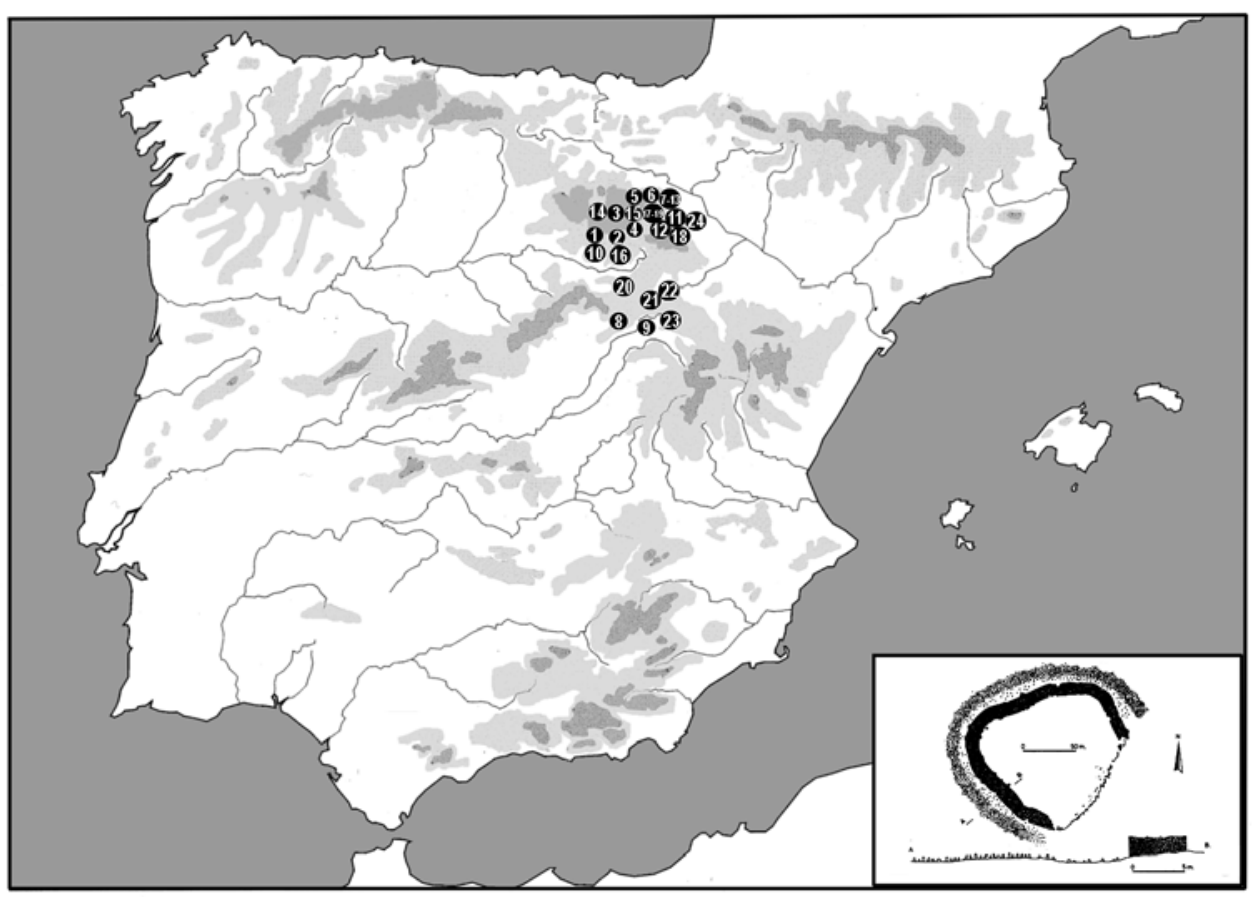

\begin{tabular}{|c|c|c|c|c|c|c|c|c|}
\hline$N^{N}$ & POBLADO & EMPLAZAMIENTO & TRAZADO & APAREJO & CORTINA & FLANQUEOS & AVANZADAS & DATACIÓN \\
\hline 1 & |Alto de Arenal S. Leonardo (Soria) & |espolion & lineal & |sillares trapezoid. & Imuro simple & bastión en extremo & p.hincadas-fosos & Ss. VIII-IV a.c \\
\hline 2 & El Pico de Cabrejas Pinar (Soria) & cerro piedemonte & lineal abierto & mampost irreg. & muro en talud & $\ldots$ & p.hincadas & Ss. IV-III a.C. \\
\hline 3 & El Castillejo deLangosto (Soria) & espolion & curvilin.abierto & mampost. irreg. & muro en talud & - & p.hincadas & Ss. VI a.C..... \\
\hline 4 & El Castillejo de Hinojosa S. (Soria) & cerro piedemonte & curviln.discont & mampost irreg. & muro simple & + & p.hincadas-fosos & Ss. VI a.C..... \\
\hline 5 & El Castillejo de Valdeavellano (SO) & farallón & curvilin.abierto & mampost irreg. & muro en talud & $\ldots$ & p.hincadas & Ss.VI a.C..... \\
\hline 6 & Los Castillejos de Gallinero (Soria) & cerro sobre valle & curvilineo & mampostireg. & muro simple & $\ldots$ & p.hincadas-foso & Ss.V a.c.?... \\
\hline 7 & El Castillejo de Taniñe (Soria) & cerro piedemonte & rectilin. abierto & mampost irreg. & muro simple? & bastiones? & p. hincadas & Ss.VI-Va.C. \\
\hline 8 & Hocincavero Anguta (Guadalajara) & a) escarpe of farallín & simuoso abierto & ciclopeo & muro simple & $\ldots$ & p.hincadas-fosos & Ss.VI-III a.c. \\
\hline 9 & Castiviejo de Guijosa (Guadalajara) & a) espolón & lineal abierto & sillares regulares & muro simple? & bastión en extremo y.. & p.hincadas & Ss. VI-III a.C. \\
\hline 10 & Castillo Billido Sta. Maria (Soria) & espolón & lineal & mampost irreg. & muro simple & torre? en extremo & p.hincadas-foso & Ss.VI-IV a.C.? \\
\hline 11 & Castellares Suellacabras (Soria) & & rectlineo & mampost. irreg. & paramentos mult. & torre? en extremo & - & Ss. Via.C...... \\
\hline 12 & Castillejo de Castiffrio S. (Soria) & cerro destacado & curvilin.abierto & mampost irreg. & muro simple & $\ldots$ & p.hincadas-foso & Ss.Vla.C..... \\
\hline$\overline{13}$ & Zarranzano Cubo de la S. (Soria) & espolion & rectilin. abierto & & muro simple & & $+\ldots$ & Ss.VI-IV a.C. \\
\hline 14 & Castillo de El Royo (Soria) & & rectilin. abierto & & muro simple & bastión? en extremo & $\ldots$ & Ss.VI-III a.C. \\
\hline 15 & Torre Beteta de Villar de Ala (Soria) & & & & & bastion? & $\ldots-\ldots . . .$. & \\
\hline 16 & Castellones de Calatañazor (Soria) & cerro piedemonte & rectlin.abierto & mampost irreg. & paramentos mútt. & - & linea exterior & \\
\hline 17 & Castillo de Arévalo de la S. (Soria) & cerro en páramo & curvilineo & cielopeo & paramentos mult. & + & foso & Ss. Va.C.... \\
\hline 18 & Torrecilla de Valdegeña (Soria) & espolón & lineal abierto & & & & $\ldots$ & \\
\hline 19 & Castillejo de Ventosa de la S. (SO) & cerro sobre valle & eurvilineo & & & torres? & foso y antemuro? & Ss. III a.C..... \\
\hline 20 & Cerro Hontalivilla (Soria) & cerro sobre valle & rectlin. abierto & mampost irreg. & muro simple & - & foso & Ss. IV a.c.... \\
\hline 21 & La Coronilla de Velilla M.ed.(Soria) & cerro & & & & & & Ss. VI a.C.... \\
\hline 22 & Alto de Solana de Sagides (Soria) & espolón & & & & & & Ss. V a.C. \\
\hline 23 & Cabeza Marachel (Guadalajara) & espolón & & & & & & Ss. VIa.c. \\
\hline 24 & Inestrillas 1 (Logroño) & cerro sobre valle & lineal abierto & ciclópeo & cajones & 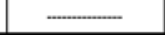 & foso & Ss. IV a.C..... \\
\hline
\end{tabular}

Figura 11: Distribución de los poblados fortificados según el «modelo de las Serranías Orientales Meseteñas» y algunos de sus yacimientos representativos 


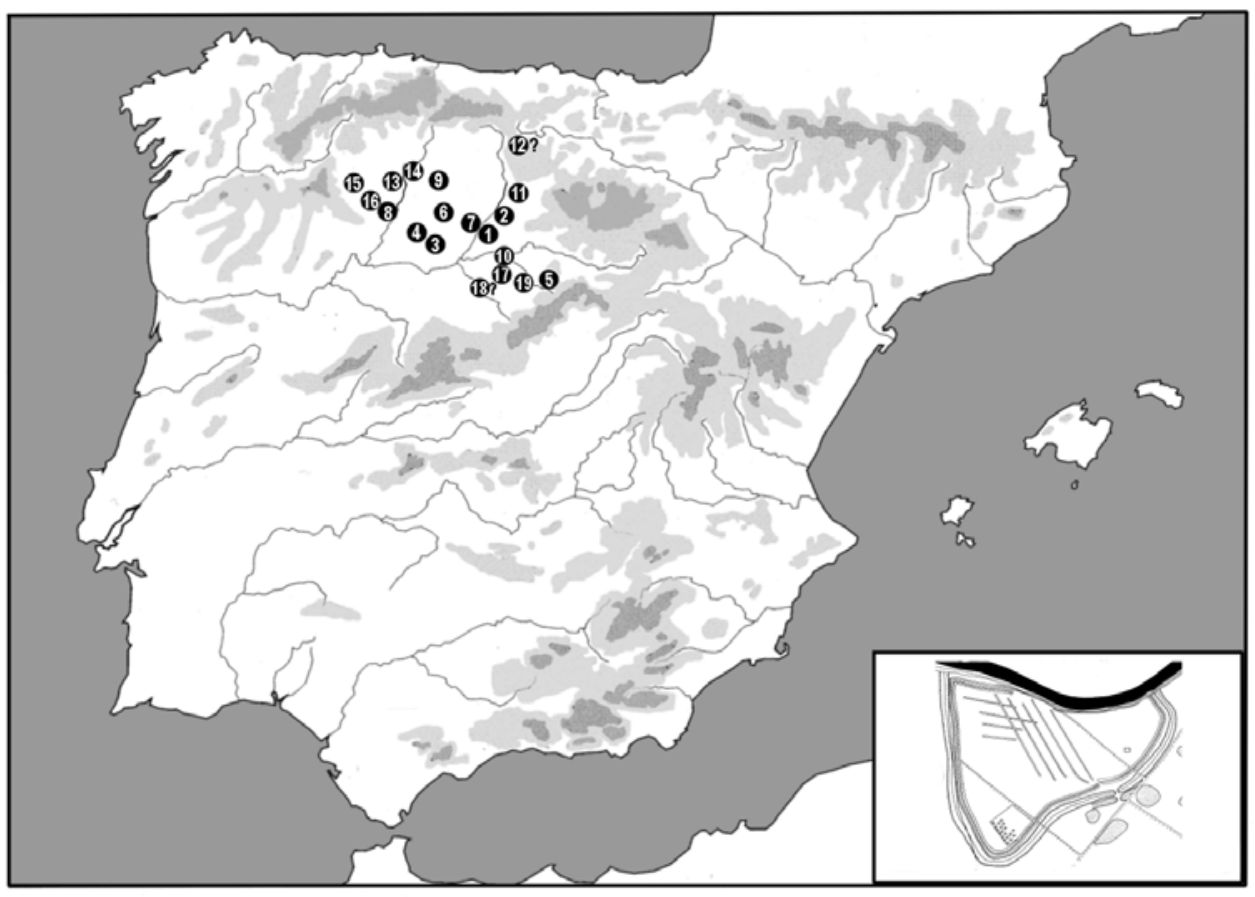

\begin{tabular}{|c|c|c|c|c|c|c|c|c|}
\hline $\mathbf{N}^{\circ}$ & POBLADO & EMPLAZAMIENTO & TRAZADO & APAREJO & CORTINA & FLANQUEOS & AVANZADAS & DATACIÓN \\
\hline 1 & Soto de Medinila (Nalladolid) & Itell en terraza fluvial & lineal abierto & adobe, piecta.... & |muro a tongadas & 1 & foso doble & Ss. V-III aC. \\
\hline 2 & Quirtanas de Valoria (Valladolid) & tell en terraza fluvial & lineal abierto & adobe, madera... & $\ldots$ & - & foso & Ss V aC.... \\
\hline 3 & Cuesta Castro (Valladolid) & cerro testigo & Ineal discont & adobe, pizara.... & $\ldots$ & $\ldots$ & foso ¿antiguo? & Ss. VI-III aC. \\
\hline 4 & Nes" Tiedra (Nalladolid) & espolón & \multicolumn{2}{|c|}{ curvininea abie adobes? } & $\cdots$ & $\cdots$ & $\ldots$ & s. V a ac. \\
\hline 5 & Cassillo de Ayllón (Segovia) & cerro en terraza fiu. & Ineal? & $?$ & $?$ & + & foso? & Ss VI- aC. \\
\hline 6 & Teso Mimbre (Nalladolid) & cerro en valle fuvial & lineal & adobes? & $\ldots$ & - & foso & Ss. V-III aC. \\
\hline 7 & E Cementerio de Cabezón (NA) & espigón tuvial & Ineal & adobes? & $\cdots$ & $\cdots$ & foso & S. VI ac. \\
\hline 8 & Cuestos de la Estación (Zamora) & tell en terraza fluvial & linea? & madera, adobes? & - & $\ldots$ & foso & svil?ac... \\
\hline 9 & Melgar de Abajo (León) & tel en espigón fuvial & Ineal & madera, adobes? & 3. - & $\cdots$ & $=$ & Ss.VIII aC. \\
\hline 10 & Las Quirtanas de Padila (NA) & tel en terraza fluvial & lineal abierto & adobes, madera. & muro a tongadas & 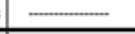 & foso & Ss.VII aC. \\
\hline 11 & Palenzuela (Palencia) & tell en espigón fluvial & Inneal abierto & adobes? & - & - & - & Ss IV aC.... \\
\hline 12 & Los Baracnes (Palencia) & espolón & lineal? & mamp. madera & muro simple, em. & - & - & Ss. Vlac.... \\
\hline 13 & Castro Ardón (León) & teell en terraza fluvial & lineal & adobe? & $\cdots$ & $\cdots$ & foso & S. Vill-V ac. \\
\hline 14 & Castro Villacelama (León) & teell en terraza fluvial & Inneal & adobes, madera & muro a tongadas & $-\ldots$ & foso & Ss. Vlac..... \\
\hline 15 & Sacagjos (León) & teell en terraza fuvial & lineal & adobes, madera & muro a tongadas & 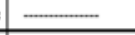 & 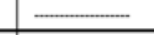 & Ss. Vlac.... \\
\hline 16 & Manganeses Polvorosa (León) & tell en espolón fuv. & Iineal & adobes, piecra & muro simple &  & - & SaVta ac. \\
\hline 17 & Castillo de Cuellar (Segovia) & cerro en terraza flus. & Ineal? & adobes, piedra & muro simple & $=$ & foso? & Ss.V aC.... \\
\hline 18 & El Mercado de Coca (Segovia) & cerro en terraza fw. & $?$ & $?$ & $?$ & $\ldots$ & foso & Ss. VH aC. \\
\hline 10 & Sampecros de S.Mguel (SG) & tell en terraza fluvial & Ineal & mamp. ciclopeo & muro simple &  & foso & Ss. IVt ac. \\
\hline & & & & & & & & \\
\hline & & & & & & & & \\
\hline & & & & & & & & \\
\hline & & & & & & & & \\
\hline & & & & & & & & \\
\hline
\end{tabular}

Figura 12: Distribución de los poblados fortificados según el «modelo del Duero Medio y Pisuerga» y algunos de sus yacimientos representativos. 
te de forma periódica o esporádica. Las escasas construcciones intramuros que se conocen estaban protegidas por murallas masivas de estructura simple (a menudo de muros en talud y a veces con paramentos múltiples), realizadas con mampuestos toscos y generalmente sin trabajar, y con sus tramos «vulnerables» defendidos mediante fosos y piedras hincadas —uno de los rasgos más conocidos, aunque en absoluto mayoritario- (Romero 1984: 210; y 2003). Prácticamente no se conocen obras de flanqueos más allá de algunos bastiones curvilíneos, aislados en los extremos y adaptados al terreno, que difícilmente se distinguen como ensanches de las gruesas murallas, incluso en algún caso más destacado como Valdeavellano de Tera (Ruiz Zapatero 1977; Moret 1991: 33; Romero 2003: 187). Pero ninguno de ellos parece responder a los criterios de «torres» pese a que suelen publicarse con tal apelativo.

Parece claro que se trataba de un modelo conceptual y técnicamente sencillo, y muy primitivo, pero tras unos siglos de ocupación generalizada entre el VI y el IV a.C., la continuidad de algunos de estos poblados se comprueba en las modificaciones y remodelaciones de sus defensas, reconocidas en los asentamientos más abiertos y en aquellos más alejados de la zona montañosa, todos con mejores condiciones de habitabilidad como se puede comprobar en el poblado de Oceanilla -Soria- o en el Castillejo de la Guijosa -Guadalajara-, o incluso en la ciudad celtíbera de Contrebia Leukade -La Rioja- (Hernández Vera 2003). En ellos se observan aplicaciones que demuestran un conocimiento de técnicas y conceptos helenísticos, a veces tan patentes como el espectacular y singular caso de la muralla de cremallera de La Guijosa.

3.3.4. El modelo defensivo de las poblaciones del Valle Medio del Duero (Ss. VI a.C. - I a. C.) se localiza en la forma de dilatados encintados en las tierras del Pisuerga, Valderaduey, Esla, Cega, y del Duero Medio en general, que se identifican con las culturas diacrónicas de Soto y Vaccea plena (Fig.: 12). Como el anterior se trata de un modelo muy característico y singularizado que muestra, en la combinación de sus elementos, pautas de comportamiento diferentes al resto de la Península Ibérica. Tales pautas aparecen ya desde el Bronce Final y se consolidan en el Hierro Antiguo conocido como «Cultura de Soto», compartiendo espacio y características con otros modelos de poblamiento en esta comarca, entre los que no son escasos los hábitats abiertos (San Miguel 1993: 24). Los fortificados prefieren emplazamientos en «llano», bien en espigón sobre los ríos principales como en las mismas llanuras aluviales, aunque no faltan asentamientos sobre cerros destacados en el páramo, aquellos que mayor incidencia histórica han tenido por su posterior fortificación durante la Edad Media. La densa ocupación temporal de unos y otros redunda en la formación de tells entre los primeros, y en la ocupación moderna y contemporánea de los segundos, de manera que esta estabilidad conforma en sí, una característica de este modelo defensivo y de poblamiento (Celis 2002: 103; Barrio 1999: 178 ss.; Sacristán et alii 1995: 361; Delibes et alii 1995: 62-63) ${ }^{20}$

También las planimetrías de estas defensas son singulares y, aunque no respondan a un modelo rígido, muestran la reiteración de trazados rectilíneos con recintos simples, compaginados con fosos en los tramos largos expuestos, o en todo su perímetro (San Miguel 2003: 53; y 1993: 36). Pero la mayor personalidad de este modelo se observa en los materiales y sistemas de construcción, pues la abundancia de suelos arcillosos favorece el uso masivo de esta tierra para los muros, a veces cocida en forma de adobe, aunque en general prensada en tongadas (que no debe confundirse con el tapial) y trabada con vigas de madera sobre un zóca-

20 «Así nos encontramos con que la mayoría de los asentamientos defendidos artificialmente responden a un tipo que muestra cierta preocupación defensiva y una preferente vocación agraria por su situación y por su emplazamientoA este modelo se ajustan, por un lado, trece poblados ribereños, fácilmente accesible, protegidos por una muralla de barro y con una dilatada ocupación (que da lugar a la formación de auténticos tell), cuyo emplazamiento fue a menudo reaprovechado por una fortificación altomedieval. A ellos se suman, por un lado, los yacimientos de Teso Mimbre y El Cementerio que, aunque con menor continuidad en su ocupación y defendidos por un foso, parecen igualmente dedicados a la explotación de las tierras de la vega en que se sitúan.» (San Miguel 1993: 29). 
lo o base de mampuestos pétreos, y bajo una empalizada como coronamiento (Centeno et alii 2003: 74-77: Misiego et alii, 1998: 29). Los elementos de flanqueo son prácticamente inexistentes, limitados a algunos ejemplos en poblados marginales del área tratada o en momentos de ocupación romano-republicanos, como el conocido Castillejo de Monte Bernorio -Palencia- o la muralla de La Mazada -Zamora- (Moret 1991: 34; Esparza 1982: 401; Esparza y Larrazabal $2000 . . . .$.$) . Y es, entonces, cuando se localizan también algunas obras realizadas en aparejo pé-$ treo como la muralla exterior de Padilla de Duero (Centeno et alii 2003: 96).

En suma, un modelo defensivo fuertemente definido por el entorno como respuesta a las necesidades de un poblamiento estable y con un alto grado de eficacia selectiva, lo que redunda en una temprana complejidad arquitectónica de componente autóctono.

3.3.5. El modelo defensivo del Cantábrico occidental (Ss. IV a.C. - I d. C.) se localiza en los valles encajonados del Navia, Narcea-Nalón y Sella, en territorio asturiano desde las rasas (Moriyón, La Campa Torres....) al prelitoral (Chao Samartín, San Chuís, Llagú....), con algún ejemplo conocido más al interior como el Castro de Chano -León- y, quizá, el también leonés Castrelín de San Juan de Paluezas, ya al sur del Duero (Fig.: 13).

Se trata de un modelo que aprovecha al máximo las ventajas de los emplazamientos muy condicionados por la orografía, ya en la costa con tipos «cliff castles» como en el interior en ladera o espigón, siendo el origen de todos ellos prerromano, derivado de las murallas lineales del Hierro Antiguo - El Olivar, Camoca - e incluso del Bronce Final - Chao Sanmartín, O Castro- (Camino 2002 y 1999; Villa 2002; Arias 2002;.....). Estos poblados son fortificados con recintos sencillos y adaptados, con trazados curvilíneos a menudo abiertos, y complementados con fosos y terraplenes, o taludes, que circunvalan los poblados y refuerzan sus accesos principales (Camino 1995: 156-158, 170; Villa 2002: 174). Este recinto, principal o único, suele estar delimitado por los accidentes naturales en algunos tramos y por una verdadera muralla de aparejo pétreo, posiblemente coronada con empalizadas. Esta muralla presenta, de nuevo, una estructura constructiva singular denominada «de módulos» por los densos compartimentos que la componen y que interpretamos como la respuesta especializada a un medio lluvioso sobre una litología blanda. Pero por su singularidad pudo trascender del mero uso utilitario, según podría explicar el caso de la muralla prerromana del Chao Samartín, donde sólo la apariencia es modular pues recubre al exterior la vieja cerca muraria de estructura continua: «el proceso de construcción consistió en la compartimentación de la primitiva línea de muralla en unidades a las que se añade una fachada oblonga que oculta o superpone, según los casos, a los viejos lienzos dañados.» (A. Villa 2002: 180). Además, la complejidad reflejada por este modelo se confirma por la ausencia de obras de flanqueo integradas, excepto en casos en los que se constata presencia de módulos adelantados desde la cortina amurallada y emplazados junto a las entradas, de manera que configuran puertas «en esviaje» según se documenta en La Campa Torres y en Llagú al menos desde el siglo IV a. C. (Maya y Cuesta 2001; Berrocal-Rangel et alii 2002: 106). Otro tipo de obras, ya compartidas con otros muchos castros del Noroeste, son los llamados «antecastros», que se localizan generalmente frente a la entrada principal combinados con fosos y terraplenes.

A partir del siglo II a. C., y especialmente a mediados del I d. C., se conocen las primeras torres, a veces de planta subrectangular como las de Coaña o Pendia, a veces circular como la de Llagú y San Chuís $(\dot{c})$. Suelen ser construcciones únicas y destacadas sobre las entradas, y es posible que con ellas se potencien los llamados «antecastros» (Romero 1976: 46; Villa 2002: 168). Pero esto sería, ya, otro modelo defensivo que busca emplazamientos con accesos más restringidos y con defensas en forma de fosos y terraplenes múltiples frente a ellos (p.e. O Corno de Villadún -Castropol, Asturias-), o con fosos y terraplenes alternos a lo largo de sus perímetros (p.e. La Barquerona de Foncalada -Villaviciosa, Asturias-), todos ellos datados en plena época romana (Camino 1995: 132-133). De igual manera las murallas 


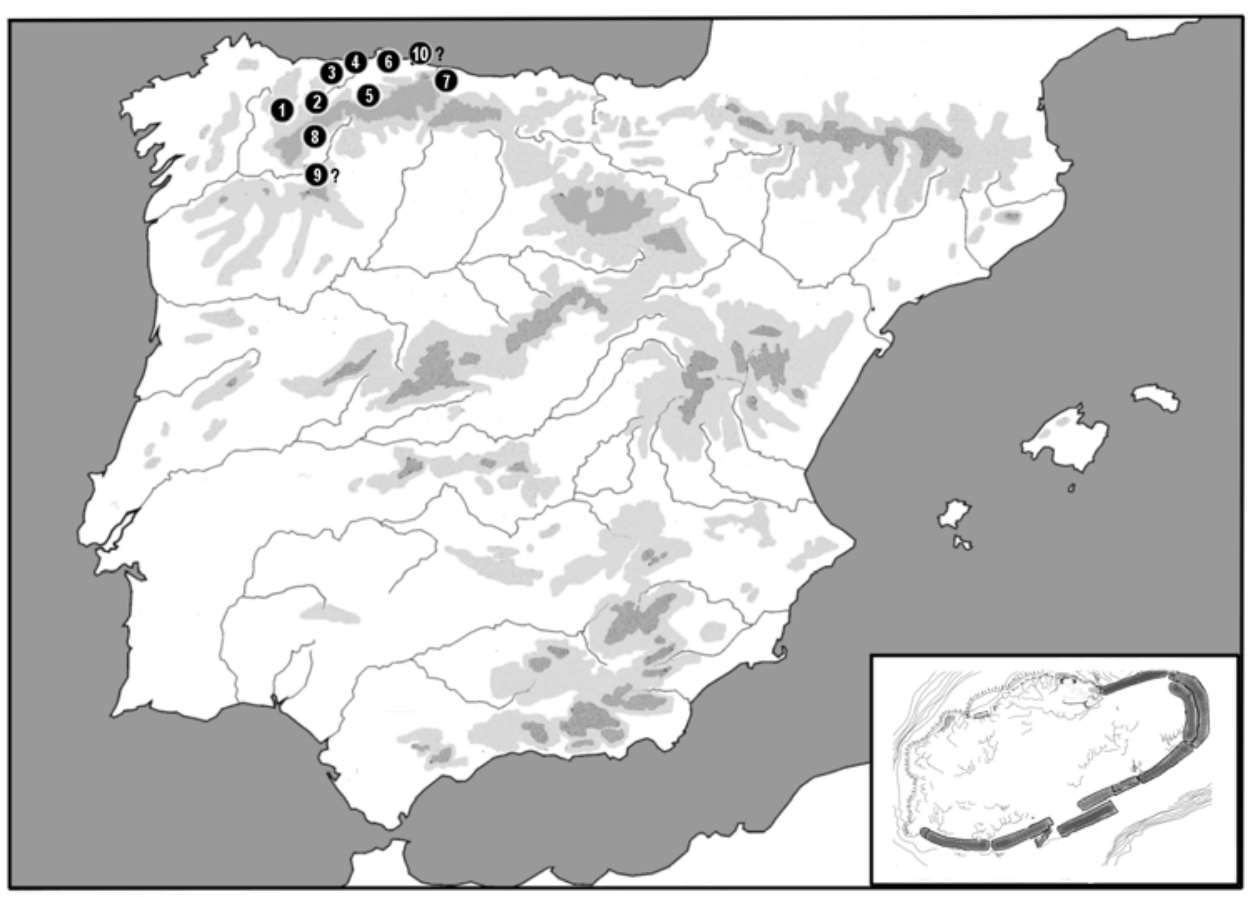

\begin{tabular}{|c|c|c|c|c|c|c|c|c|}
\hline $\mathrm{N}^{\circ}$ & POBLADO & EMPLAZAMIENTO & TRAZADO & APAREJO & CORTINA & FLANQUEOS & AVANZADAS & DATACIÓN \\
\hline 1 & Chao Samartin 3 (Astusnias) & escape y ladera & auvīneo & |mamposteria irre.| & módulos & $\ldots$ & \multicolumn{2}{|c|}{ fosos, ¿artecastro? Ss.IV aC-1 dC } \\
\hline 2 & San Chuis (Asturias) & cerro destacado valle & recblineo & mamposteria iire. & módulos & 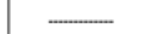 & fosos, antemuro & Ss.IV aCl dC \\
\hline 3 & Castillo Veneiro (Asturias) & espigón fluvial & rectilineo & mamposteria irre. & móduos & $\ldots$ & foso y talud & S.ll aCl dC \\
\hline 4 & Castillo San Martin (Asturias) & cerro desembocadura & $?$ & mamposteria irre. & módilos & $-\ldots$ & $?$ & Ss.IV aC.... \\
\hline 5 & Castiellu de Lagù (Asturias) & cerro en valle fluvial & curvilineo & mamposteria irre. & módulos & muro adelantado & foso y antecastro & Ss.IVt ac. \\
\hline 6 & La Campa Torres (Asturias) & perinsula costera & arvilineo & mamposteria irre. & modulos & módulo adelantado & foso $y$ antemuro & S. VaC.... \\
\hline 7 & Castiellu de Moriyón (Asturias) & cerro piedemonte & cuvvilineo? & mamposteria irre. & módulos & 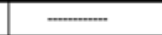 & $?$ & Ss.IVH ac. \\
\hline 8 & Castro de Chano (León) & ladera en espolón & curvilineo & mamposteria irre. & modios & $\ldots$ & foso & Ss.ll a/d C. \\
\hline 9 & Castrelin de S. Juan de P. (León) & & curvilinea & mamposteria irre. & módulos? & bastión o torre redo. & foso & Ss. Il a/dC. \\
\hline 10 & Picu Catalin (Asturias) & cerro costero & curvilinea & mamposteria irre. & módulos? & $\overline{-}$ & foso y antecastro & $?$ \\
\hline & & & & & & & & \\
\hline & & & & & & & & \\
\hline & & & & & & & & \\
\hline & & & & & & & & \\
\hline & & & & & & & & \\
\hline & & & & & & & & \\
\hline & & & & & & & & \\
\hline & & & & & & & & \\
\hline & & & & & & & & \\
\hline & & & & & & & & \\
\hline & & & & & & & & \\
\hline & & & & & & & & \\
\hline & & & & & & & & \\
\hline & & & & & & & & \\
\hline & & & & & & & & \\
\hline
\end{tabular}

Figura 13: Distribución de los poblados fortificados según el «modelo del Cantábrico occidental» y algunos de sus yacimientos representativos. 

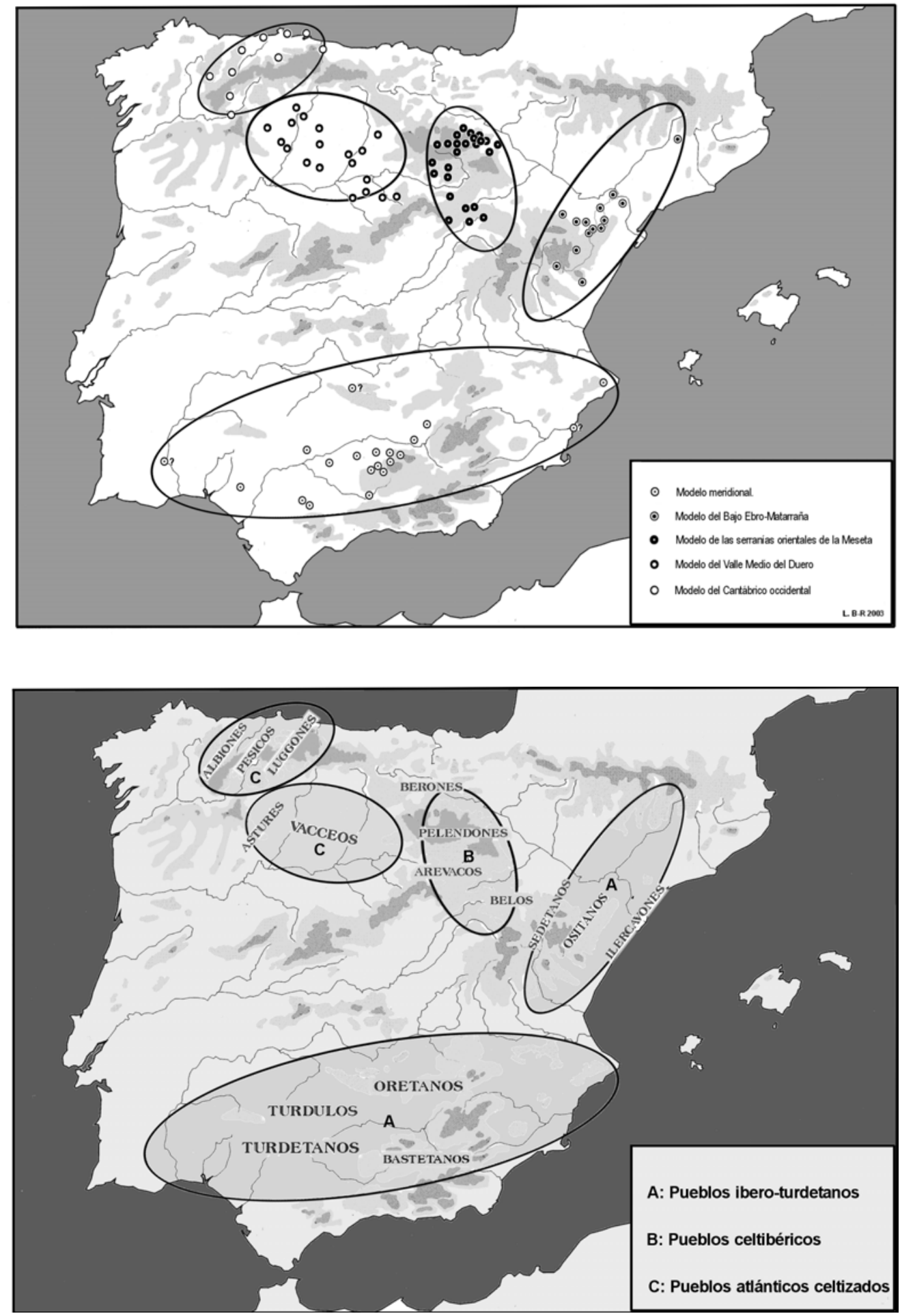

Figura 14: Agrupaciones de los modelos propuestos y su relación con el territorio adjudicado a las grandes etnias prerromanas descritas en los textos greco-latinos, según la distribución propuesta por los diversos autores responsables de cada territorio en Paleoetnología de la Península Ibérica (Almagro-Gorbea y Ruiz Zapatero, eds., 1992). 
son, ahora, lineales continuas (Coaña, Pendia.....) y, de nuevo, antecedidas en sus accesos por varios fosos y parapetos, cuando no por las piedras hincadas de los castros de San Isidro y el Picu La Mina, que son excepciones en este entorno (en Carrocera 1990).

En suma, los cinco modelos propuestos demuestran la existencia de pautas defensivas concretas de naturaleza indígena que coinciden con vastas regiones y culturas arqueológicas de la Península Ibérica en época protohistórica desde el Bronce Final a finales del Hierro II (Ss. VIII - II a. C.).

Este panorama descarta los territorios fuertemente afectados por las presencias coloniales fenicias, púnicas o griegas, aunque también en ellos la singularidad indígena se manifiesta, como hemos explicado, no «copiando» los modelos fortificados coloniales que, rara vez, se conocen fuera de las costas (Emporion, Santa Pola, Cartago Nova, La Silla del Moro - Malaka, Carteia, Cádiz, Niebla......). Por ello, y porque hemos considerado y defendido la base colectiva o comunitaria de estas construcciones, creemos que es posible relacionar y quizá identificar estos modelos constructivos con diferentes entidades culturales o étnicas (macroetnias, populi, gentes, divisiones administrativas romanas.....), aclarándose previamente que tales entidades no responden más que vagamente a los conceptos definidos por S. Shennan y otros investigadores de la naturaleza comunitaria (1989: 14 ss.).

3.4. La capacidad de generar diferentes modelos, consecuencia de las identidades comunitarias.

Como cuarta premisa de este trabajo planteamos la posibilidad de interpretar las peculiaridades de estos modelos como reflejos de las distintas características comunitarias de las poblaciones que los proyectaron y los construyeron. Reiterando que, como la misma naturaleza mutable de tales comunidades, los modelos de fortificaciones que proponemos deben considerarse como conceptos flexibles que no responden a criterios cerrados o rígidos, sería factible su consideración en relación con las siguientes trayectorias culturales y étnicas (Fig.: 14):

3.4.1. Con el poblamiento de oppida del Alto Guadalquivir entre los siglos VI y III a.C. se identifica el modelo defensivo meridional, un fenómeno muy concreto que tradicionalmente se interpreta dentro de las dinámicas sociales novedosas que suceden el final del poder supuestamente centralizado y adjudicado a Tartessos (Escacena y Fernández Troncoso 2002). Su presencia en los enclaves centrales de amplias regiones del Sur les hace paradigmas de una de las tramas del poblamiento más compleja y jerarquizada de la Península (Ruiz y Molinos 1993: 113 ss. y 191 ss.), y permite relacionarlos con diversas grandes etnias, populi prerromanos que comparten entre sí un desarrollo social de vieja raigambre, gestado durante siglos de relación oriental, primero, y de sus relaciones abiertas y no pocas presencias puntuales con las colonias fenicias y púnica, después (Aubet 1987). Por tanto la representatividad de este modelo responde a este trasfondo común, que tiene mucho de complejidad social y política, y que no se corresponde a las demarcaciones étnicas habituales en el resto de la Península, posiblemente porque la imagen étnica consolidada por los escritores greco-latinos (Polibio, Estrabón, Plinio, Apiano) refleja un panorama más tardío, cuando este modelo había sido abandonado junto con gran parte de estos oppida (como agudamente suponen Ruiz y Molinos: «el vacío étnico producido por el modelo de los oppida [del siglo VI] ha mantenido los rasgos étnicos del período anterior, dejando ver una unidad más amplia: 1993: 266-267).

En efecto, todo apunta a que, este modelo de oppida en el Guadalquivir, debe remitir a una situación anterior, aquella que es creída ser descrita en obras como el supuesto «periplo massaliota» de la Ora Marítima de Rufo Festo Avieno. Aunque no es más que una conjetura, 
es interesante ver en la amplitud del modelo un reflejo de la extensión de las grandes etnias de los siglos VI a.C. y V a. C. (tartesios, etmaneos, mastienos.....), como otros posibles elementos-traza han planteado con anterioridad (p.e. los vasos con pintura polícroma: Murillo 1989, o las cajas funerarias: Almagro-Gorbea 1982). Pero sobre los numerosos intentos y dificultades de distinción de estas macroetnias, y de los populi que las integraban, es obligada una consideración general de prudencia como demuestra la síntesis realizada por J. L. Escacena (2000: 114-126). Por ello sólo es factible considerar que, entre los siglos VI - IV a.C., se estuviera gestando un nuevo panorama, fraguado a partir del abandono de algunos de estos hábitats fortificados y de la aparición de otros: «Todo nos lleva a pensar en que hacia esta fecha (siglo III a. C.) volvemos a encontrar la reconstrucción de nuevas etnias que, sin embargo y a pesar de su inicial pujanza, verán truncado su desarrollo con la conquista del territorio por Roma. Por otra parte, la aparición de [estas] nuevas etnias o nominaciones grupales asimiladas a oppida (oretanos a Oreto, bastetanos a Basti o mentessanos a Mentessa) refuerza la idea de una realidad generada o reforzada políticamente a lo largo del siglo III a.C.....», resumen magistralmente la situación A. Ruiz y M. Molinos (1993: 247-248).

3.4.2. Los asentamientos del Bajo Ebro y, posiblemente del cercano territorio valenciano del Turia y del Júcar, responden a diferentes pautas como reflejo de otras tantas realidades complejas y jerarquizadas que comparten el generalizado interés por dar prioridad al control visual extenso del territorio. Por ello al encastillamiento generalizado, entendido de manera expandida del Norte al Sur entre los siglos VII y V a.C. mediante pequeños poblados «cerrados de espacio central», sucede una organización más o menos cerrada que, en relación con las fortificaciones y otros elementos-traza (comarcas naturales, cerámicas, monedas,.....), ha servido para definir diferentes territorios étnicos, especialmente identificados con la potenciación de los oppida. Los ositanos, sedetanos, ilercavones y edetanos no sólo muestran desarrollos diferenciales desde el Bronce Final, sino que comparten esta característica con el resto de etnias históricas del litoral catalano-valenciano, incrementando sus diferencias mediante la identificación de los populi con sus oppida: Ilerda con los ilergetes, Osicerda entre los ositanos; Celse - Velilla de San Antonio con los sedetanos; Edeta - Tossal de Liria con los edetanos, etc. (Padró y Sanmartí 1992: 190-192; Sanmartí y Belarte 2001: 172; Burillo 2001-2002; Benavente, Marco y Moret 2003: 242-243).

En torno a estos territorios se localizan diversos modelos de hábitat fortificados como los referidos del Bajo Ebro, especialmente identificado en las corrientes subsidiarias de Guadalope, Matarraña y Algás, donde los poblados con acrópolis (Azaila, El Palao) y los asentamientos menores con torres huecas de planta curva (San Cristóbal de Mazaleón, Torre Cremada, Torre de Foios, Coll del Moro.....) reflejan un asentamiento homogéneo y personalizado, con escasos préstamos coloniales, y con una relación clara con la etnia ositana (Burillo, 1998: 298-299; 2001-2002; Moret, 2002). Algunos casos más dudosos aparecen alejados, en los territorios considerados ilercavones o ilergetes, ya en Lérida, con el poblado de Castelvel, como en Castellón, con el Puig de la Nau. Pero la presencia de otros modelos de defensas en el Bajo Ebro confirma la complejidad del Bajo Ebro con otros ejemplos significativos como los representados por los poblados del Turó del Montgrós y del Casoll de Puigcastellet, para los P. Moret no duda en calificarlos como ejemplos de un modelo de poliorcética local que identifica como «ausetano» (2000: 211).

3.4.3. Inicialmente los castros sorianos monopolizaron el modelo de las serranías orientales de la Meseta Norte, una solución muy concreta que refleja un contexto cultural muy homogéneo, claramente definido por los arqueólogos desde los trabajos de B. Taracena (1941; Romero 1984 y 1991; García Huerta 1990......). Sin duda, la estrecha relación de su poblamiento con la intrincada orografía de montaña y los pasos obligados de la Meseta Sur 
al Valle del Ebro permite comprender la búsqueda de puestos de control para ser ocupados en lo alto por estos pequeños e inaccesibles castros, especialmente sobre los pasos naturales que comunican los recursos ganaderos y mineros entre el Alto Jalón y el Alto Mesa y Tajuña (Jimeno y Martínez Naranjo 1999: 176). Por ello, cuando las condiciones sociales y económicas muestran la aceptación de un cambio generalizado a partir del siglo IV a. C., sus fortificaciones serán abandonadas (Castilfrío) o radicalmente transformadas (Oceanilla), a la par que se consolida una extensión del hábitat que ocupa tierras más pródigas y cercanas a los cauces del Duero y del Tajo.

Esto significa un desfase cronológico que altera la tradicional adscripción étnica propuesta por Taracena para los castros sorianos como solar de los Celtíberos pelendones citados durante la Conquista romana, como observaron Bachiller y Ramírez al adjudicar parte de estos poblados al territorio de los arévacos (p.e., Oceanilla, Fuensaúco), previo al conocido episodio de la cesión —o devolución— de Numantia (1983; Hernández Guerra 1993; Burillo 1998: 193-199). Frente a tal dato A. Ocejo ha propuesto un desplazamiento de la etnia pelendona hacia el Norte en época romana, factible pese a que se basa en Ptolomeo (1995), una fuente tan confusa como tardía y de cuestionable o descartable utilidad en estos fines (Gómez Fraile 2001: 50; y 1997). Sea como fuere, no nos caben dudas que el modelo de poblamiento fortificado de las serranías orientales de la Meseta Norte refleja una entidad étnica al menos entre los siglos VI y IV a.C. y que, grosso modo, esta etnia podría ser o preceder a los llamados pelendones, pobladores en suma del Alto Duero (una síntesis reciente sobre las dificultades en la identificación territorial de estos pelendones y sus posibles emplazamientos en Gómez Fraile 2001: 99-106).

3.4.4. Algo más al Oeste, en las vegas y páramos vallisoletanos, palentinos y burgaleses del Pisuerga, Sequillo y Cega, y del Duero Medio en general incluyendo gran parte de la cuenca leonesa y zamorana del Esla, los poblados responden a patrones bien establecidos y definidos desde antiguo, con un fuerte componente antrópico. De ahí la destacada personalidad del modelo representado, uno de los más interesantes del suelo peninsular.

Esta constatación se asienta en la aceptación de un poblamiento con una evolución nítida y con una cultura material homogénea (Sacristán et alii 1995: 361-362; San Miguel 1995 y 1993.....). En él, la contribución de un paisaje muy singular, las parameras meseteñas y las campiñas que intercalan, juega un papel importante, cuya máxima consecuencia se reflejará en las llamadas civitates vacceas. En efecto, su identificación con esta gran etnia prerromana es aceptada en general, aunque presente problemas de detalle si se pretende restringir, como en otros casos, a territorios con fronteras determinadas, un fenómeno fundamentalmente ya romano. Así, poblaciones reconocidas como arévacas (la misma Clunia), al Oeste de La Demanda, reflejan este modelo y su contexto, cosa que no ocurre una vez atravesado el Sistema Ibérico. Y tampoco son nítidos los límites septentrionales con los Turmogos, como ocurría entre los Pelendones (Sacristán et alii 1995: 363-364).

Pero, como en el poblamiento del Bajo Ebro-Júcar, el Duero Medio pivota su identidad prerromana en torno a grandes oppida que, sin entrar en una dinámica estrictamente urbana, reflejan una complejidad paralela. Así «La civitas sería, de algún modo, la forma que adoptaría la gens en su territorio tras el proceso de catalización urbana», aunque tras esta organización «urbana» subyace una estructura indígena gestada en un desarrollo estable y secular (Sacristán 1995: 370 y 372). No parece por tanto que se constaten inconvenientes graves para la identificación vaccea de este modelo de poblamiento fortificado, incluso cuando la investigación en Historia Antigua destaca la integración de las llamadas civitates en entornos claramente romanos (Gómez Fraile 2001: 84-95; Sánchez Moreno 1998; Salinas 1994.....). No obstante el modelo responde también a causalidades que modificaron su comportamiento y cuyo reflejo parece tener respuesta en este panorama tardío y tergiversado transmitido por los romanos. Así, a la 
notable reducción del número de poblados desde la Facies Soto, frente a la prerromana, acompaña una posible dispersión del modelo hacia el Norte y el Oriente — de los Turmogos, Berones y Caristes - frente a un retroceso por el Oeste, que se incorpora por entonces al Mundo astur-galaico (Sacristán et alii 1993: 363 ss.).

3.4.5. Por último, en gran parte de las tierras asturianas, se documenta un contexto poblacional que aúna un peculiar sistema de defensa asociado a rasgos constructivos y materiales propios de la Cultura castreña del Noroeste (De Blas y Villa, 2002). En principio sólo en su núcleo más oriental, en torno a la ría del Sella y sus afluentes, es posible constatar el peso de las relaciones con la Meseta vaccea (Camino Mayor 2003), pero no en una entidad suficiente como para apreciar claras distinciones de base con el resto del poblamiento del Noroeste. Por ello, y por la unicidad relativa que manifiestan estos poblados fortificados desde el Navia al Sella, creemos que es factible hablar de un modelo defensivo del Cantábrico occidental entre los siglos IV a.C. y I d. C., aunque en La Campa Torres y en Llagú se ha planteado un arranque anterior (Maya y Cuesta 2001: 55; Berrocal-Rangel et alii 2002: 319).

Pero aquí el problema se suscita cuando intentamos cotejar este modelo con los conocimientos étnicos sobre los astures transmontanos, porque gran parte de estos poblados fortificados se emplazan al Oeste del curso del Navia, fuera del ámbito territorial de estos (Mohías, Coaña, Pendia, San Isidro, Chao Samartín,......). Tradicionalmente este territorio es adscrito a los albiones, populus considerado galaico debido a una cita específica de Plinio (Nat. Hist., IV, 20, 111: «los paesici, y tras ellos, el Conventus lucensis a partir del río Navia, con los albiones, cibarci, egi.....») - (Lomas 1988: 35; Santos Yanguas 1992: 422; Fernández Ochoa y Morillo 1999: 22-23). La adscripción fue corroborada posteriormente en la obra tolemaica (que cita el Nauialbion: Geog. II, 6, 4) y por el hallazgo en las proximidades de Piantón (Vegadeo) de la conocida lápida funeraria de Nicer Clutosi, príncipe albión del castro Cauriaca (García y Bellido 1943: 418 ss.). Así quedaría cerrada la cuestión de la identificación galaica de estos territorios occidentales, si no fuese por la naturaleza funeraria de la lápida, que implica la procedencia externa del difunto (Albertos 1975: 65), lo que redundaría en la posibilidad de que los albiones se situaran en otros parajes. A ello contribuye también la cita de Ptolomeo, pues el geógrafo griego nombra dos desembocaduras consecutivas, las del citado Nauialbion y, a continuación, la del Nabia y, después, «de los paesicos, Flauionavia....» (Geog. II, 6, 4). Es decir que el hidrónimo «Navia» era habitual en el Oeste asturiano, como sabemos por la epigrafía (Prósper 2002: 189-195), y por tanto es factible que sea causa de confusiones. Así, si la asimilación albiones = Nauia parece ser correcta no queda claro a cual de estas Navias se refiere. Por ello, ya J. M. González había propuesto la reducción Navia = río Eo y Navialbión = río Navia (1954; Fernández Ochoa y Morillo 1994 y 1999: 28), lo que conlleva reconocer que los albiones se emplazaban fuera y dentro del territorio asturiano, ya en la provincia de Lugo como en el Principado, un caso de división étnica por parte de la Administración romana que tiene paralelos tan claros como los Célticos del Alentejo y de la Baeturia (Berrocal-Rangel 1992). Pero esto no supone más que una conjetura entre términos tan próximos y reiterados como el Nauia o Lucus, en uno y en el otro territorio de las supuestas macroetnias astur y galaica.

En suma este modelo defensivo, que por el momento no rebasa geográficamente la cuenca del Sella por el Oriente, refleja una configuración étnica que englobaría los populi luggones, pésicos y albiones «orientales», considerando a estos como los habitantes de los territorios del actual río Navia y denunciando, con ello, una posible comunidad de pueblos desconocida, solo gran parte asimilable a los posteriormente llamados «astures transmontanos». 


\section{CONCLUSIONES}

Como avance prospectivo sobre las posibilidades de una línea de investigación mucho más extensa y compleja ${ }^{21}$, aportamos los siguientes puntos:

1. El presente estudio defiende el reconocimiento del valor del poblamiento fortificado como referente sintomático de las pautas étnicas, que identificaron las comunidades protohistóricas peninsulares.

2. Estas poblaciones presentan un escaso o nulo desarrollo protoestatal y urbano, y se estructuran en comunidades afines o adscribibles a la categoría de «jefaturas de fuerte carácter guerrero ${ }^{22}$ « a partir de una fecha ambivalente entre los siglos VI y IV según los diferentes desarrollos culturales.

3. Esta estructuración se comprende tras la consolidación de la estabilidad de las redes de intercambio a larga distancia abiertas al menos desde el Bronce Final, mediante un proceso de afianzamiento territorial de las comunidades que desemboca, indefectiblemente, en la fortificación generalizada de su poblamiento.

4. Tales comunidades cristalizarán en la forma de populi generalmente asociados a sus principales núcleos habitados, oppida que se definen por su naturaleza y etimología como «poblados fortificados».

5. Esta carga étnica se reflejará en la construcción de los perímetros «amurallados» como las obras colectivas de mayor envergadura emprendidas por estas comunidades, tanto en medios materiales como en recursos humanos.

6. Dichos amurallamientos, además de ser emblemas de la identidad comunitaria por su carga defensiva, son referentes interiores y exteriores del paisaje y de la sociedad protohistórica, asumiendo costumbres constructivas e ideológicas, favoreciendo capacidades experimentales y facilitando la adaptación de ideas foráneas según las necesidades y los condicionamientos físicos y sociales de cada comunidad.

7. Como consecuencia, las formas y técnicas constructivas aplicadas a la defensa del poblamiento reflejarán diferentes modalidades según el contexto cultural y étnico donde se emplacen, no constatándose nunca la importación de modelos mediterráneos - más allá de las cercanías de las colonias-, sino la adaptación de algunos de sus elementos defensivos, especialmente durante el período Helenístico sea cual fuere el foco irradiador (griegos, púnicos, fenicios o romanos).

8. En tal sentido es posible definir algunos modelos defensivos del poblamiento que pueden proyectar rasgos representativos de las distintas comunidades en diferentes niveles. Los modelos aquí propuestos muestran su desarrollo entre los siglos VI a.C. y III a. C. en los casos más meridionales, y IV a. C. y I d. C. en los más septentrionales, dependiendo su final de la irrupción y transformación social impuesta por púnicos o romanos.

9. Estos rasgos demuestran que las comunidades protohistóricas estaban fuertemente estructuradas antes de la llegada de los romanos y que sus demarcaciones macroétnicas pueden ser detectadas mediante el estudio de sus fortificaciones a fin de proceder

21 En vías de inicio dentro del proyecto BHA2003-02199 Las fortificaciones prerromanas de la Península Ibérica. Estudio e inventario de las defensas protohistóricas de la Meseta y la Vertiente Atlántica (Ss. VIII - I a.C.) - (FPPI), en colaboración con los Dres. Álvarez-Sanchís (UCM), Castelo Ruano (UAM), Lorrio Alvarado (UA), Lucas Pellicer (UAM), Moret (EHHH Casa de Velázquez) y Zarzalejos Prieto (UNED).

22 Con este discutido epígrafe aludimos a la identificación de los estamentos de poder por medio de los valores bélicos. 
a su cotejo con otros materiales supuestamente significativos y, especialmente, con las informaciones étnicas recogidas por la Administración romana.

10. En tal sentido, las posibilidades de interpretación de esta capacidad emblemática se comprueba en los casos de estudio prospectados: los cambios denunciados por el poblamiento fortificado del Sur de la Península en ámbitos post-tartésicos conocidos como «túrdulo-turdetanos» a partir del siglo VI a. C., primero, y del III a.C., posteriormente, demuestran la naturaleza mutable incluso de las comunidades más desarrolladas de la Península. Por el contrario, en los valles del Bajo Ebro donde las comunidades indígenas presentan una perduración incluso bajo el dominio inicial romano, sus demarcaciones son fiel reflejo de las prerromanas (Ilercavones, Sedetanos, Ositanos, Edetanos). El fenómeno se repite, con cierta cercanía formal, en el interior de la Meseta Norte entre los pueblos conocidos como vacceos, sin duda por la fuerte personalidad cultural que los caracteriza, mientras sus vecinos sobre las serranías orientales demuestran una transformación tardía de sus patrones que parece conducir, en el siglo III a.C., a una nueva y poco singularizada definición bajo el etnónimo de Pelendones. De igual manera, en el confín cantábrico, los conocidos como astures transmontanos reflejan una homogeneidad notable en el sistema defensivo de sus poblados desde épocas muy anteriores a la presencia romana que, cuando acontece, limita y divide parte de las comunidades que configuraron esta macroetnia, adjudicando sus poblaciones occidentales a la Administración de la Gallaecia lucense.

\section{LUIS BERROCAL RANGEL}

Departamento de Prehistoria y Arqueología. Universidad Autónoma de Madrid. luis.berrocal@uam.es

\section{BIBLIOGRAFÍA}

ABreu, M. SimÔES DE; ARCA, A.; JAFFe, L.; FossATI, A., 2000: «As gravuras rupestres da Idade do Ferro no Vale de Vermelhosa (Douro - Parque Arqueológico do Vale do Côa).», III CAP (Vila Real 1999), Proto-História da Península Ibérica (Berrocal-Rangel et alii, eds.), 403-412,

ADAM, J.-P., 1982: L’Architecture militaire grecque. CNRS - Picard, París.

Aguayo De Hoyos, P., 1977: «Construcciones defensivas en la Edad del Cobre Peninsular. El Cerro de los Castellones Laborcillas, Granada).», CPUG, 2: 87-104.

Albertos Firmat, M.L., 1975: Organizaciones suprafamiliares en la Hispania Antigua., Studia Archaeologica,37, Santiago de Compostela.

Alfaro ArRegui, M., 1991: «El sistema defensivo de la puerta de entrada a la ciudad ibérica de Meca (Ayora, Valencia).», Fortificacions - La problemàtica de l'iberic ple (Manresa 1990):147-152.

Alfaro, C.; Broncano, S., 1990: Los caminos de rueda de la ciudad ibérica del Castellar de Meca (Ayora, Valencia)., EAE, 139, Madrid.

Almagro-GorbeA, M., 1982: «Tumbas de cámara y cajas funerarias ibéricas. Su interpretación sociocultural y su delimitación del área cultural.», Hom. a Conchita Fernández Chicarro: 249-257, Sevilla.

Almagro-Gorbea, M., 1994: «El urbanismo en la Hispania Céltica: castros y oppida.», Castros y oppida en Extremadura (Almagro-Gorbea y Martín, eds.), Extra Complutum, 4:13-76. 
Almagro-GorbeA, M., 1995: «Aproximación paleoetnológica a la Celtiberia meridional: las serranías de Albarracín y Cuenca.», Poblamiento Celtibérico. III Simposio sobre Celtíberos (Burillo, ed.): 433-446, Zaragoza.

Almagro-GorbeA, M., 1996: Ideología y poder en Tartessos y el Mundo Ibérico., R.A. H., Madrid.

Almagro-GorbeA, M., 2003: «La escultura en la Hispania Céltica.», Die lusitanischgalläkischen Kriegerstatuen, MDAI (M), 4: 150-161.

Almagro-GorbeA, M.; Gran-Aymerich, J., 1992: El estanque monumental de Bibracte (Mont Beuvray, Borgoña)., Complutum, Extra, 1, Madrid.

Alonso, N.; JunYent, E.; LAfuente, A.; LÓPEZ, J.B. (eds.), 2003: Chevaux-de-frise i fortificació en la Primera Edat del Ferro Europea., Universitat de Lleida, Lleida.

ÁlvareZ-SANCHís, J. R., 1999: Los vettones., BAH, 1, Madrid.

Álvarez-SANCHÍs, J. R., 2003: Los señores del ganado. Arqueología de los pueblos prerromanos en el Occidente de Iberia. Akal Arqueología, Madrid.

Amores Carredano, F., 2002: Fortificaciones en el Entorno del Bajo Guadalquivir., Actas del Congreso Internacional (Alcalá de Guadaira 2001), Sevilla.

ArCelin, P.; Dedet, B., 1985: «Les enceintes protohistoriques du Midi Mediterranéen des Origines à la fin du IIeme. Siécle av. J.-C.», Les enceintes protohistoriques de Gaule meridionale (Recherche Arch. Languedoc Oriental, 14): 11-37, Caveirac.

ARIAS VILAS, F., 2002: «Las fases de la Cultura castreña en Galicia.», Los poblados fortificados del NW (De Blás y Villa, eds.): 127-137, Navia.

ARLEGUI, M., 1992: «El yacimiento celtibérico de Castilmontán, Somaén (Soria): El sistema defensivo.», II Symposium Arqueología Soriana (Soria 1989), I: 495-513.

ARMENDARI MARTIJA, J., 1998 : «Las Eretas. Arquitectura doméstica y defensiva de un poblado del Hierro Antiguo en el Alto Ebro.», Revista de Arqueología, 210: 28-35.

ARriBAS, A.; 1983: «Excavaciones en Los Millares (Santafé, Almería). Campañas de 1982 y 1983», CPUG, 8: 123-147

Arteaga, O.; Padró, J.; SAnMartí, E., 1990: El poblado ibérico del Tossal del Moro de Pinyeres (Batea, Terra Alta, Tarragona)., Monografies Arqueològiques, 7, Barcelona.

Asensio EsteBAn, J.A., 1995: La ciudad en el Mundo prerromano de Aragón., Zaragoza.

AubagnaC, G., 1990: «L'enceinte de Constantine (Lançon, Bouches-du-Rhône) et se valeur militaire.», RAN, 23: 53-70.

Aubet Semmler, M.E., 1987: Tiro y las colonicas fenicias de Occidente., Bellaterra, Barcelona.

Aubet Semmler, M.E.; Serna, M.R.; Escacena, J.L.; Ruiz Delgado, M.M., 1983: La Mesa de Setefilla, Lora del Río (Sevilla) - Campaña de 1979., EAE, 122, Madrid.

Audouze, F.; Buchsenschutz, O., 1989: Villes, villages et campagnes de l’Europe Celtique, París.

BAKHUIZEN, S.C., 1986: «La gran batterie de Goritsa et l'artillerie défensive.», La fortification dans l’ Histoire du Monde Grec (Leriche y Treziny, eds.): 315-322.

BARril Vicente, M., 1995: «El castro de Los Baraones (Valdegama, Palencia). Un castro en el Alto Valle del Pisuerga.», Poblamiento Celtibérico (F. Burillo, ed.): 399-408.

BARRIO MARTín, J., 1999: La II Edad del Hierro en Segovia (España). Estudio arqueológico del territorio y de la cultura material de los pueblos prerromanos., BAR IS, 790, Oxford.

Belarte Franco, C., 1997: Arquitectura domèstica y estructura social a la Catalunya Protohistòrica., Barcelona. 
BELTRÁN LlORIS, M., 1995: Nuevas aportaciones deducidas de la documentación inédita de Juan Cabré Aguiló., Zarazgoza.

Benavente, J.A.; Marco, F.; Moret, P., 2003: «El Palao de Alcañiz y el Bajo Aragón durante los ss. II y I a.C.», en F. Pina, ed., Ciudad y romanización en el Valle Medio del Ebro, AEspA, 76: 231-246.

Benavente, J.A.; Moret, P., 2002: «El poblado ibérico tardío de Torre Cremada (Valdetoro, Teruel). Un hábitat fortificado del siglo I a.C. en el Bajo Aragón.», Ibers a l’Ebre. Recerca i interpretació (Tivissa 2001), Ilercavònia, 3: 221-228.

Bendala Galán, M., 2003: La ciudad, Ayer y Hoy., Real Academia de Doctores, Madrid.

BernaBeU, J.; BONET, E.; MATA, C., 1987: «Hipótesis sobre la organización del territorio edetano en época ibérica plena: el ejemplo del territorio Edeta / Iliria.», Iberos (Jaén 1985): 137-176.

Bernabeu, J.; GuitART, I.; PAscuAL, J.L., 1989: «Reflexiones en torno al patrón de asentamiento en el País Valenciano entre el Neolítico y la Edad del Bronce.», Saguntum, 22: 99.123.

Bernabeu, J.; Orozco, T.; DíEz, A.; Gómez, M.; MolinA, F.; 2003: «Más d’Is (Peñáguila, Alicante): aldeas y recintos monumentales del Neolítico inicial en el Valle del Serpis.», TP: 60 (2): 39-54.

Berrocal-RAngel, L., 1992: Los pueblos célticos del Suroeste de la Península Ibérica., Extra Complutum, 2, Madrid.

Berrocal-RAngel, L., 1994-a: «Oppida y castros en la Beturia Céltica.», Castros y oppida en Extremadura (Almagro-Gorbea y Martín, eds.), Extra Complutum, 4: 189-242, Madrid.

BERROCAL-RANGEL, L., 1995-b: «Arqueología de las fortificaciones griegas (III). Repercusiones entre los púnicos, íberos y celtas.», Revista de Arqueología, 166: 24-35.

BERROCAL-RANGEL, L., 2003-a: «La expansión meridional de los chevaux de frise: los castros célticos del Suroeste.», Chevaux-de-frise i fortificació en la Primera Edat del Ferro Europea (Alonso et alii, eds.): 209-232, Lleida.

Berrocal-RANGeL, L., 2003-b: «Poblamiento y defensa en el territorio céltico durante la Época republicana.», en A. Morillo, M. Cadiou, D. Hourcade, eds., Defensa y territorio en Hispania de los Escipiones a Augusto: 185-218, Casa de Velásquez - Universidad de León, Salamanca.

Berrocal-Rangel, L.; Martínez Seco, P.; Ruiz, C., 2002: El Castiellu de Llagú. Un castro astur en los orígenes de Oviedo., BAH, 13, Madrid.

Bettencourt, A.M., 2000: «O mundo funerário da Idade do Ferro do Norte de Portugal. Algumas questôes.», III CAP (Vila Real 1999), Proto-História da Península Ibérica (Berrocal-Rangel et alii, eds.), 43-60.

BEWLEY, R., 1994: Prehistoric Settlements., English Heritage Book, Batsford, London.

Blasco Bosqued, C., 2001: «El poblamiento en las cuencas de los ríos Duero y Tajo.», Entre Celtas e Iberos (Berrocal-Rangel y Gardes, eds.), BAH, 8: 201-212, Madrid.

Blasco Bosqued, C.; Alonso SÁnchez, M.A., 1986-1987: «Paralelos arquitectónicos entre la Meseta Norte y el Alto Tajo durante la II Edad del Hierro.», Col. Int. La Edad del Hierro en la Meseta Norte, Zephyrus, XXXIX-XL: 159-168.

BlÁZQUEZ MARTínEZ, J.M., 1987-1988: «Los mercenarios hispanos en las fuentes y la arqueología.», Habis, 18-19: 257-270.

BlÁzQuez Martínez, J.M., GarcíA-GElabert, M.P., 1991: «El armamento depositado en la necrópolis del Estacar de Robarinas (S. IV a.C.). Alta Andalucía.», Festschrift für W. Schüle zum 60. Internatinale Archäeologie, 1: 41-54. 
BONET, H.; MATA, C., 1991: «Las fortificaciones ibéricas en la zona central del País Valenciano.», Fortificacions - La problemàtica de l'iberic ple (Manresa 1990): 11-35.

Bonet, H.; MATA, C., 2001: «Organización del territorio y poblamiento en el País Valenciano.», Entre Celtas e Iberos (Berrocal-Rangel y Gardes, eds.), BAH, 8: 175-186, Madrid.

Bouloumie, B., 1990: «Sur la question d'une éventuelle présence etrusque au bord de la Baltique.», Problemy Kultury Luzychiej na Pomorzu (Malinowsky, T. Ed.), Sluppsk.

BRIARD, J., 1995: Les mégalithes de l'Europe atlantique. Architecture et art funéraire., Errance Ed., París.

Brun, P., 1995: «From chiefdom to state organization in Celtic Europe.», Celtic Chiefdom, Celtic State (Arnold y Gibson, eds.): 13-25, Cambridge U.P.

BRUN, P., 2001: «Échelles d'intégration politique et contrôle des moyens de production en Europe.», Entre Celtas e Iberos (Berrocal-Rangel y Gardes, eds.), BAH, 8: 29-44, Madrid.

Buchsenschutz, O.; RAlston, I.., 1981: «Les fortifications des Âges Metaux.», Archéologia, 154: 24-36.

BuchsenschutZ, O.; Guillamet, J.-P.; RAlstOn, I., eds., 1999: Les remparts de Bibracte. Recherches récentes sur la Porte du Rebout et le tracé des fortifications, Coll. Bibracte, 4, Glux-enGlenne.

BuChSEnsChutZ, O.; IZAC, L., 2000: «L'habitat de l’Âge du Fer dans le Quercy historique. », en B. Dedet et alii, eds., Aspects du l'Âge du Fer dans le Sud du Massif Central : 105-116.

BuchsenschutZ, O., 2001: «Habitat et société celtique: la tentation urbaine.», Entre Celtas e Iberos (Berrocal-Rangel y Gardes, eds.), BAH, 8: 109-115, Madrid.

Bueno Ramírez, P.; Municio, L.; Alvarado, M.; GonzÁlez, A., 1988: «El yacimiento de El Jardinero (Valencia de Alcántara).», EA, I: 89-102.

Burillo Mozota, F., 1998: Los Celtíberos. Etnias y estados., Crítica Arqueología, Barcelona.

Burillo MozotA, F., 1999: Segeda (Mara - Belmonte de Gracia). La ciudad celtibérica que cambió la Historia., Seminario Arqueología y Etnología Turolense, Zaragoza.

Burillo Mozota, F., 2001-2002: «Propuesta de una territorialidad étnica para el Bajo Aragón: Los Ausetanos del Ebro u Ositanos.», Kalathos, 20-21: 170-187.

Burillo Mozota, F., 2003: «Segeda. Arqueología y Sinecismo.», en F. Pina, ed., Ciudad y romanización en el Valle Medio del Ebro, AEspA, 76: 193-215.

CABré Aguiló, J., 1944: Corpus Vasorum Hispanorum. La Cerámica de Azaila, CSIC, Madrid.

Cabré Aguiló, J.; Cabré De Morán, E.; Molinero, A., 1950: El castro y la necrópolis del Hierro Céltico de Chamartín de la Sierra (Ávila)., Acta Arqueológica Hispana, V, Madrid.

CAmino MaYor, J., 1995: Los castros marítimos de Asturias., Instituto de Estudios Asturianos, Oviedo.

CAMINO MAYOR, J., 2000: «Las murallas compartimentadas en los castros de Asturias: Bases para un debate.», AEspA, 73: 27-42.

CAMINO MAYOR, J., 2003: «Los castros de la Ría de Villaviciosa: Contribución a la interpretación de la Edad del Hierro en Asturias.», TP, 60-I: 19-171.

CARballo ArXeO, L. X., 1990: «Los castros de la cuenca media del Río Ulla y sus relaciones con el Medio físico.», TP, 47: 161-199.

Carballo ArXeO, L. X., 1993: «Espacio e povoamento castrexo de Galiza.», Concepcións espaciais e estratexias territoriais na Historia de Galiza: 55-82, Santiago. 
CARMan, J.; HARDING, A.F., 1999: Ancient Warfare. Archaeological perspectives., Stroud Sutton Publ., Wiltshire.

CARROCERA FERNÁNDEZ, E., 1990: «El castro de San Isidro: Informe de las excavaciones arqueológicas 1986.», Excavaciones Arqueológicas en Asturias, 1: 157-162.

CASTleden, R., 1993: The Stonehenge people. An exploration of life in Neolithic Britain 47002000 BC., Routledge, London and New York.

Celis SÁnchez, J., 2002-a: «El Bronce Final y la Primera Edad del Hierro en el Noroeste de la Meseta.», Los poblados fortificados del NW (De Blás y Villa, eds.): 97-126, Navia.

CELIS SÁNCHEZ, J., 2002-b: «La ocupación castreña en el alto valle del Cúa: el Castro del Chano, León.», Los poblados fortificados del NW (De Blas y Villa, eds.): 189-210, Navia.

Centeno Cea, I.; Sanz, C.; Velasco, J.; Gallardo, I., 2003: «Aproximación al urbanismo vacceo-romano de Pintia.», Pintia. Un oppidum en los confines orientales (Sanz y Velasco, eds.): 6998, Valladolid.

Cerdeño Serrano, M.L.; García Huerta, M.L.; Arenas, J., 1995: «El poblamiento celtibérico en la región del Alto Jalón y del Alto Tajo.», Poblamiento Celtibérico. III Simposio sobre Celtíberos (Burillo, ed.): 157-178.

Cerdeño SerRano, M.L.; MARTín, E., 1995: «Sistemas defensivos de un castro celtibérico: El Ceremeño de Herrería.», Poblamiento Celtibérico. III Simposio sobre Celtíberos (Burillo, ed.): 185-190.

Снавот, L., 1983: «L'Oppidum de La Cloche aux Pennes - Mirabeau (Bouches-du-Rhône). Synthèses des travux affectués de 1967 à 1982.», RANarb, 16: 39-80.

Chapman, R., 1991: La formación de las sociedades complejas. El sureste de la Península Ibérica en el marco del Mediterráneo Occidental., Crítica Arqueología, Barcelona.

CiAsCA, A., 2000: «Technique muraire e fortificazioni puniche in Sicilia», Fenicios y Territorio (J.M. González Prats, ed.): 57-70, Alicante.

CIPRÉS, P., 2002: «Instituciones militares indoeuropeas en la Península Ibérica.», La Guerra en el Mundo ibérico y celtibérico (Moret y Quesada, eds.) Coll. Casa Velázquez, 78: 135-152, Madrid.

CoIGNARD, R.; CoIGNARD, O., 1991: «L'ensemble lapidaire de Roquepertouse: nouvelle approche.», Documents d'Archéologie Méridionale, 14: 28-29.

Collis, J., 1989: La Edad del Hierro en Europa., Labor edt., Barcelona.

Collis, J., 1993: «Structures d’habitat et enceintes de l'Âge du Fer.», Fonctionnement social de l'Âge du Fer (Daubigney, ed.): 231-238, Lons-le-Saunier.

Collis, J.; Krausz, S.; Guichard, V., 2000: «Les villages ouverts en Gaule central aux IIème et Ier siècles av. J.-C.», en V. Guichard, S. Sievers, O.H. Urban, eds., Les processus d'urbanisation à l'Âge du Fer, Bibracte 4 : 73-82, Glux-en.Glenne.

CONTRERAs CORTÉs, F., 1993: «Análisis histórico de las comunidades de la Edad del Bronce del Alto Guadalquivir.», Investigaciones arqueológicas en Andalucía 1985-1992 (VI Jornadas Arqueología Andaluza): 439-440, Huelva.

CorreiA, V.H., 1995: «The Iron Age in South and Central Portugal and the Emergence of Urban Centres.», Social Complexity and the Development of Towns in Iberia (Keay y Cunliffe, eds.), Proc.Brit.Acad., 86: 237-262.

Correia, V. H., 2001: «O povoamento do Noroeste no $1^{\circ}$ Milénio a. de C.», Entre Celtas e Iberos (Berrocal-Rangel y Gardes, eds.), BAH, 8: 213-226, Madrid. 
Correia, V.H.; Burgess, C., e.p.: «Habitats fortificados da tardía Idade do Ferro e Roamanorepublicanos na área de Évora: Quadro geral e problemática.», Defensa y territorio en Hispania de los Escipiones a Augusto (Morillo, Hourcade, Cadiou, eds.), CCV, Madrid - León.

CUNLIFFE, B., 1978: Iron Ages Communities in Britain., London.

CunlifFe, B., 1982: «Settlement hierarchy and social change in Southern Britain in the Iron Age.», Analecta Praehistorica Leidensia, 15. London.

CunLIFFE, B., 1988: Greeks, Romans and Barbarians. Spheres of Interaction., Batsford Ltd.,

Cunliffe, B.; Fernández CAstro, M.C. 1987: «Torre Paredones (Castro del Río - Baena, Córdoba). Informe preliminar. Campaña 1987: prospección arqueológica con sondeo estratigráfico.», AAA 1987 (II). Actividades sistemáticas: 193-199.

DARCQUE, P., 1992: «Les fortifications mycéniennes.», Les fortifications grecques de Mycenes a Alexandre, Les Dossier d'Archéologie, 172: 12-19.

Delibes de Castro, G.; Fernández Manzano, J., 2000: «La trayectoria cultural de la Prehistoria reciente (6000-2500 BP) en la Meseta Norte española.», 3 CAP (Vila Real 1999), Pre-história recente da Península Ibérica, IV: 95-122, Porto.

Delibes de Castro, G.; Fernández Manzano, J.; Fontaneda, E.; Rovira, S.,1999: «Metalurgia de la Edad del Bronce en el poblamiento meridional de la Cordillera Cantábrica. La Colección Fontaneda», Arqueología en Castilla y León. Monografías, 3, Zaragoza.

Delibes de Castro, G.; Romero, F.; Sanz, C.; Escudero, Z.; San Miguel, L.C., 1995: «Panorama arqueológico de la Edad del Hierro en el Duero Medio.», en Delibes et alii, eds., Arqueología y Medio Ambiente. El Primer Milenio A.C. en el Duero Medio: 49-146, Valladolid.

DíAZ-DEL Río, P., 2003: «Recintos de fosos del III Milenio AC en la Meseta peninsular.», TP: 60 (2): 61-78.

DÍAZ MARTíNEZ, E., 2003: «An alternative hypotheses for the origin of ferroan ringwoodite in the pumice of El Gasco (Cáceres, Spain).», Lunar and Planetary Science, XXXIV: 1318.

Dies Cusí, E., 1991: «Funcionalidad de las torres en las fortificaciones del Camp del Turia (Valencia): defensa, vigilancia y señales.», Fortificacions - La problemàtica de l'iberic ple (Manresa 1990): $171-178$.

DíEs CUSÍ, E., 2001: «La influencia de la arquitectura fenicia en las arquitecturas indígenas de la Península Ibérica (s. VIII-VII).», Arquitectura Oriental y Orientalizante en la Península Ibérica (Ruiz Mata y Celestino, eds.): 69-122, Madrid.

EsCaCena CARRASCO, J.L., 2000: La Arqueología Protohistórica del Sur de la península Ibérica., Arqueología Prehistórica de Sítensis, 4, Madrid.

EsCaCENA CARRASCO, J.L.; FernÁNDEZ TRONCOSO, G., 2002: «Tartessos fortificado.», Fortificaciones en el Entorno del Bajo Guadalquivir (Amores, ed.):109-134, Sevilla.

Esparza Arroyo, A., 1982: «Reflexiones sobre el castro de Monte Bernorio (Palencia).», Publicaiones de la Institución Tello Tellez de Henáres, 42: 395-408.

ESPARZA ARROYO, A., 1986: Los castros de la Edad del Hierro en el Noroeste de Zamora., Zamora.

FABIÂO, C., 1998: O Mundo indígena e a sua Romanizaçâo na área céltica do territorio hoje português., Disertaçâo de doutoramento, Universidade de Lisboa.

FANTAR, M. H., 1984: Kerkouane, cité punique du Cap Bon, I., Túnez.

FANTAR, M. H., 2000: «Urbanisme et l'architecture puniques : les cas de Kerkouane», Fenicios y Territorio (J.M. González Prats, ed.): 71-88, Alicante. 
FERnÁNDEZ CASTRO, M.C.; CUnLIFFe, B. W., 2002: El yacimiento y el santuario de Torreparedones. Un lugar arqueológico preferente en la campiña de Córdoba., BAR IS, 1030, Oxford.

Fernández Corrales, J.M.; SAUCedA, M.I.; RodríGueZ, A., 1988: «Los poblados calcolíticos y prerromano de Los Castillejos (Fuente de Cantos, Badajoz).», Extremadura Arqueológica,1: 69-88.

FERNÁNDEZ JURADO, J., 1987: Tejada la Vieja: una ciudad protohistórica., Huelva Arqueológica, IX, Huelva. 20-31.

FERNÁNDEZ OCHOA, C., 1992: «Excavaciones en la anigua Sisapo», Revista de Arqueología, 132:

FERnÁNDEZ OCHOA, C.; MORILlo Cerdán, A., 1994: De Brigantium a Oiasso. Una aproximación al estudio de los enclaves marítimos cantábricos en época romana., Madrid.

Fernández OCHOA, C.; MoRILlo CerdÁN, A., 1999: La tierra de los astures. Nuevas perspectivas sobre la implantación romana en la antigua Asturia., TREA SL, Gijón.

FERnÁndez-Posse, M. D., 1998: La investigación protohistórica en la Meseta y Galicia., Arqueología Prehistórica, 1, Madrid.

Fernández-Posse, M. D.; Montero, I.; SÁncheZ-Palencia, F. J.; Rovira, S., 1993: «Espacio y metalurgia en la Cultura Castreña: El Castrelín de San Juan de Paluezas.», TP, 50: 197-220.

FichtL, S., 2001: La ville celtique. Les oppida de 150 av. J.C. à 15 ap. J.-C., errance, París.

FORTEA, J.; BERNIER, J., 1970: Recintos y fortificaciones ibéricas en la Bética., Salamanca.

Fried, M., 1967: The Evolution of Political Society: an Essay in Political Economy., Random House, New York.

Fustel DE COUlANGES, N.D., 1983[1864]: La ciudad antigua., Iberia edit., Barcelona.

GasCo, J., 2000: «L'enceinte du Cros de Caunes - Minevois (Aude) à la transition Âge du Bronze - Âge du Fer. Ouvrages architecturaux et aménagement.», en B. Dedet et alii, eds., Aspects du l'Âge du Fer dans le Sud du Massif Central: 183-192.

Gibson, C.; CorreiA, V.H.; BuRgess, C.B., 1998: «Alto do Castelinho da Serra (Montemor-oNovo, Évora, Portugal). A preliminary report on the excavations at the Late Bronze Age to Medieval site 1990 - 1993.», Journal of Iberian Archaeology, 0: 189-244.

G.I.P. (Grupo D’ InVestigació Prehistòrica), 2003: «Caballos y hierro. El campo frisio y la frtaleza de Els Vilars d'Arbeca (Lleida, España)., Chevaux-de-frise i fortificació en la Primera Edat del Ferro Europea (Alonso et alii, eds.): 233-274, Lleida.

García Huerta, M.R., 1990: La Edad del Hierro en la Meseta Oriental: El Alto Jalón y el Alto Tajo., Col. Tesis Doctorales, 50/90, UCMadrid.

GaRCía SANZ, C., 1987: «Excavación de la muralla de Tejada.», Tejada la Vieja: Una ciudad protohistórica (Fernández Jurado, ed.), Huelva Arqueológica, 9: 93-105.

García y Bellido, A., 1943: «Los Albiones del Noroeste de España y una estela hallada en el Occidente de Asturias.», Emerita, XI: 418-422.

GARLAN, Y., 1974: Recherches de Poliorcétique Grecque., École Française d'Athènes, De Boccard, Paris - Athenes.

GARLAN, Y., 1992: «La fortification, un fait de civilisation.», Les fortifications grecques de Mycenes a Alexandre, Les Dossier d'Archéologie, 172: 36-41.

Gomes, M. VARela, 1993: «O estabelecimiento fenício-púnico do Cerro da Rocha Branca (Sílves).», Os fenícios no territorio português (Estudos Orientais, IV): 73-105, Lisboa. 
Gómez Berllard, C., Guerin, P.; Dies, E.;PERES, G., 1993: «El vino en los inicios de la Cultura ibérica. Nuevas excavaciones en l'Alt de Benimaquia, Denia.», Revista de Arqueología, 142: 16-27.

Gómez Fraile, J.M., 1997: «La geografía de la Hispania Citerior en C. Tolomeo: análisis de sus elementos descriptivos y aproximación a su proceso de elaboración.», Polis, 9: 183-247.

Gómez Fraile, J.M., 2001: Los celtas en los valles altos del Duero y del Ebro., Memorias Seminario de Historia Antigua, VIII, Alcalá de Henares.

González Prats, A.; García Menarguez, A.; Ruiz Segura, E., 1997: «La Fonteta. Un ciudad fenicia en Occidente.», Revista de Arqueología, 190: 8-13.

GOnZÁLEZ-TABLAS, F.J.; ARIAS, L.; BENITO, J.M., 1986: «Estudio de la relación relieve/sistemas defensivos de los castros abulenses.», Arqueología Espacial, IX: 113-126.

GonzÁlez-TABlas, F.J.; DOMínguez Calvo, A., 2002: Los Castillejos de Sanchorreja (Ávila): Campañas de 1981, 1982 y 1985., Acta Salmanticensia, Estudios Históricos y Geográficos, 117, Salamanca.

Gracia AlOnso, F., 1997: «L’Artillerie romaine et les fortifications ibériques dans la Conquête du Nord-Est de la Penínsule Ibérique (218-195 av. J.-C.)., L'Équipement militaire et l'armament de la Republique (Feugère, ed.: ROMEC X), JRMES, 8: 171-195.

Gracia Alonso, F., 1999: «Arquitectura y poder en las estructuras de poblamiento ibéricas. Esfuerzo de trabajo y corveas.», Los Iberos. Príncipes de Occidente: 99-114, Barcelona.

Gracia AlONSO, F., 2000: «Análisis táctico de las fortificaciones ibéricas.», Gladius, XX: 131-170.

GRACIA AlONSO, F., 2001: «Sobre las fortificaciones ibéricas. El problema de la divergencia respecto al problema único.», Gladius, XXI: 155-166.

Gracia Alonso, F., 2003: La guerra en la Protohistoria. Héroes, nobles, mercenarios y campesinos., Barcelona.

Gracia Alonso, F.; Munilla, G., 2000: El libro de los iberos. Viaje ilustrado a la Cultura ibérica., Signament - El Mèdol, Tarragona.

Gracia Alonso, F.; Munilla, G.; García, E.; Vicent, A., 1999: «La transición de los siglos VII-VI a. C. En el área de la desembocadura del Ebro.», II CAP (Zamora 1996): 101-112.

GRAU MiRA, J., 2002: La organización del territorio en el área central de la Contestania ibérica., Publicaciones de la Universidad de Alicante.

GUICHARD, V.; SiEvers, S.; URBAN, O., eds., 2000: Les processus d'urbanisation à l'âge du Fer. Eisenzeitliche Urbanisationsprozesse., Coll. Bibracte, $n^{\circ} 4$ (Colloque Juin 1998), Glux-en-Glenne.

Guilaine, J.; Zammit, J., 2002: El camino de la Guerra. La violencia en el Prehistoria., Ariel Prehistoria, Barcelona.

GUITART DuRÁN, J., 1975: «Nuevas piezas de esculturas prerromanas en Cataluña: restos de un monumento con relieve en Sant Martí Sarroca (Barcelona).», Pyrenae, 11: 71-79.

HARBISON, P., 1968: «Castros with chevaux-de-frise in Spain and Portugal.», MDAI (M), IX: 116-147.

Harding, A. F., 2003: Sociedades europeas en la Edad del Bronce., Akal Prehistoria, Barcelona.

HERNÁNDEZ GUERRA, L., 1993: «Los pelendones: territorio y costumbres.», H.Ant., XVII: 21-50, Valladolid.

HeRnÁNDEZ VerA, J. A., 1982: Las ruinas de Inestrillas. Aguilar del Río Alhama. Estudio arqueológico., Logroño.

Hernández VerA, J. A., 2003: «Contrebia Leukade y la definición de un nuevo espacio para la Segunda Guerra Púnica.», SALDVIE, 3: 61-82. 
HoGG, A.H.A., 1957: «Four Spanish Hill-forts.», Antiquity, XXXI: 25-32.

HoGG, A.H.A., 1975: Hillforts of Britain., London.

HourCADE, D.; LOPES, V.; LABARTHE, J.-M., 2003: «Mértola: la muraille de l'Âge du Fer.», Revista Portuguesa de Arqueología, 6 (1) : 175-210.

HURTADO PÉREZ, V., 1990: «Informe de la segunda campaña de excavaciones en el yacimiento de El Trastejón (Zufre, Huelva).» A.A.A. 1990: 716-181.

Hurtado Pérez, V.; García SAnjuán, L., 1994: «Áreas funcionales en el poblado de la Edad del Bronce de El Trastejón (Zufre, Huelva).», Arqueología en el entorno del Bajo Guadiana: 239-271, Huelva.

Jimeno Martínez, A.; Arlegui, C., 1995: «El poblamiento en el Alto Duero.», Poblamiento Celtibérico. III Simposio sobre Celtíberos (Burillo, ed.): 93-126, Zaragoza.

JiMENo MARTíneZ, A.; Benito, J. P., 1999: «Las defensas numantinas.», III CAP (Zamora 1996): 303-311.

Jimeno Martínez, A.; Martínez Naranjo, J. P., 1999: «El inicio de la Edad del Hierro en el núcleo hidrográfico Alto Jalón - Alto Duero.» En J. Arenas y D. Palazón, eds., El origen del Mundo Celtibérico: 165-189, Guadalajara.

Johnson, A.W.; EARLe, T., 2003: La evolución de las sociedades humanas., Ariel Prehistoria, Barcelona.

Jorge, S. OliveirA, ed., 2003: Recintos murados da Pré-História Recente. Ediçôes DCTPFLUP, Porto.

JuÁrez, J.M.; CÁCERES, P.; Moreno, E., 1998: «Estepa tartésica: Excavaciones en el Cerro de San Cristóbal.», Revista de Arqueología, 208: 16-23.

KalB, Ph.; HÖCK, M., 1987: «O Tejo na zona de Alpiarça (Idades do Bronze e Ferro).», A. S. Silva ed., Arqueología no Vale do Tejo: 48-52.

KARLSSON, L., 1992: Fortification towers and masonery techniques in the hegemony of Syracuse, 405-211 BC., Estocolmo.

KEAY, S., 2002: «Fortificaciones en el Bajo Guadalquivit durante el final de la Edad del Hierro y la Época Romana Inicial.», Fortificaciones en el Entorno del Bajo Guadalquivir (Amores, ed.): 81108, Sevilla.

Kimmig, W., 1983: Die Heuneburg am der oberen Donau., Führer zu archäologischen Denkmälen in Baden-Wüttemberg., 1, Stuggart.

KRAuSSE, D.; NAKOINZ, O. (2000): «Binnenkolonisation und Zentralisation über legungen zur latènezeitlichen Besiedlungs - und Bevölkerungsentwicklung im Mittelgebirgsraum nordwestlich der Mosel.», en Guichard et alii, eds., Les processus d'urbanisation à l'Âge du Fer: 127-140.

KRISTIANSEN, K., 2001: Europa antes de la Historia., Istmo ed., Barcelona.

LERICHE, P., 1992: «Intéret de l'étude de la fortification grecque.», Les fortifications grecques de Mycenes a Alexandre, Les Dossier d'Archéologie, 172: 2-11.

LeVeque, P., 1986: «Conclusion générale.», Les Fortifications dans l'histoire du monde grec (Valbonne 1982): 378-380, París.

Lorrio Alvarado, A.J., 1997: Los Celtíberos., Extra Complutum, 7, Madrid-Alicante.

Lorrio Alvarado, A.J., 2001: «El poblado y la necrópolis de El Molón (Camporrobles, Valencia).», Los íberos en la comarca de Requena-Utiel (Lorrio, ed.): 151-170. 
LUCAS PELLICER, M.R., 1994: «Prólogo.», El Altar prerromano de Capote (L. Berrocal-Rangel): 9-14, Madrid

Martín Bravo, A. M., 1999: Los orígenes de Lusitania. El Primer Milenio A.C. en la Alta Extremadura., BAH, 2, Madrid.

Martín VAlls, R., 1985: «La Prehistoria del Valle del Duero.», Historia de Castilla y León, Ámbito, I: 94-96, Valladolid.

MARTínez GÁZQUEZ, J., 1992[1974]: La campaña de Catón en Hispania., Barcelona.

Martínez PeÑARroya, J., 2000: «Notas sobre el estado de la cuestión de los asentamientos fortificados de planta circular en la Península Ibérica durante la Prehistoria reciente.», Revista de Guimarâes, vol. I (Actas do Congresso de Proto-História Europeia, Guimarâes 1999): 389-401.

MARTins, M.; Jorge, S., 1992: «Substrato cultural das etnias pré-romanas do Norte de Portugal.», Paleoetnología de la Península Iberica (Almagro y Ruiz Zapatero, eds.), Complutum, 2-3: 347-372.

Mascort, M.T.; SANMARTí, J.; SAnTACANA, J., 1991: El jaciment protohistòric d'Aldovesta (Benifallet) $i$ el comerç fenici arcaic a la Catalunya Meridional., Publicacions de la Diputació de Tarragona, Tarragona.

MAYA GONZÁLEZ, J.L., 1983: «La Cultura castreña romana. Su etapa romano provincial.», Lancia, 1: 221-262.

Maya GonzÁlez, J.L.; CueSTA, F., 2001: El castro de La Campa Torres. Período Prerromano., UTP Editorial, Gijón.

MenA, P.; et alii, 1988: «Fosos de Bayona (Huete, Cuenca). Datos de las dos últimas campañas de excavación.», Primer Congreso de Historia de Castilla-La Mancha (Toledo 1988), IV: 183-190.

Misiego TejadA, J.C.; MARtín, M.A.; SAnZ, F.J.; MARCos, G.J.; LARRÉN, H., 1998: «Arqueología en territorio astur. La Corona / El Pesadero de Manganeses.», Revista de Arqueología, 208: 28-35.

Molina GonzÁlez, F., 1983: «La Motilla de Las Cañas (Daimiel, Ciudad Real). Campaña de 1983», CPUG, 8: 301-324

MolínA GonzÁLEZ, F., 1978: «Definición y sistematización del Bronce Tardío y Final del Sudeste de la Penínsular Ibérica.», CPUG, 3: 159-232.

Molist, N.; RoviRA, J., 1990: «La fortificació ibèrica del Turó del Montgrós (El Brull, Osona).», Fortificacions - La problemàtica de l'iberic ple (Manresa 1990): 249-264.

MorenA LÓPEZ, J.A., 2002: «El dispositivo defensivo del oppidum ibero-romano de Torreparedones.», Fortificaciones en el Entorno del Bajo Guadalquivir (Amores, ed.): 157-168, Sevilla.

Moret, P., 1990: «Fortins, tours d’Hannibal et fermes fortifiées dans le Monde ibérique.», Mélanges $C V$, XXVI (I), 5-43.

Moret, P., 1991: «Les fortifications de l’Âge du Fer dans la Meseta espagnole: origine et diffusion des techniques de cosntruction.», Melanges CV, XXVII (1): 5-42.

Moret, P., 1996: Les Fortifications ibériques de la Fin de l' Âge du Bronze à la Conquête Romaine., Coll. Casa Velázquez, 56, Madrid.

MoRET, P., 2000-2001: «Emporion et les mutations de l'Architecture iberrique au Premier Âge du Fer.», Zephyrus, 53-54: 379-391.

MORET, P., 2001-a: «Del buen uso de las murallas ibéricas.», Gladius, XXI: 137-144.

Moret, P, 2001-b: «El Tossal Montañés (Valdetorno, Teruel): une maison-tour ibérique du Vie siècle av. J.C», MM, 42: 85-101. 
Moret, P., 2002: «Les fortifications ibériques complexes. Questions de tracé et d'unité de mesure.», La Guerra en el Mundo ibérico y celtibérico (Moret y Quesada, eds.) Coll. Casa Velázquez, 78: $189-215$.

Moret, P., 2002-b: «Reflexiones sobre el período ibérico pleno (siglos V a III a.C.) en el Bajo Aragón y zonas vecinas del curso inferior del Ebro.» , en Ibers a l'Ebre. Recerca i interpretació (Tivissa 2001), Ilercavònia, 3: 111-136.

Moret, P.; BEnAVEnTE, J.A., 2000: «Nouvelles recherches sur l'habitat de l'Âge du Fer dans la Vallée du Matarraña (Bas Aragon).», III CAP (Vila Real 1999), Proto-História da Península Ibérica (Berrocal-Rangel et alii, eds.), V: 327-344, Porto.

Morillo, A.; Cadiou, F.; Hourcade, D., eds., 2003 : Defensa y territorio en Hispania. De los Escisiones a Augusto., Casa de Velásquez - Universidad de León, Salamanca.

MÜLLER, H., 1996: «Beobachtungen an Befestigungsanlagen in Katalonien. Elemente griechischer Befestingungstechnik in Emporion, Ullastret und Tivissa.», MDAI (M), 37: 86-102.

MuÑOZ, K.; MADRIGAL, A., 1999: «Poblamiento y recursos durante la Segunda Edad del Hierro en el Valle Medio del Tajo.», en F. Burillo ed., Economía. IV Simposio sobre Celtíberos: 467-479, Zaragoza.

MuRILlo Redondo, J.F., 1989: «Cerámicas tartésicas con decoración orientalizante», CupaUAM, 16: 149-169

Negueruela, I., 1990: Los monumentos escultóricos ibéricos del Cerrillo Blanco de Porcuna (Jaén), Madrid.

Nocete Calvo, F., 1994: La formación del Estado en las Campiñas del Alto Guadalquivir (3000-1500 a. C.)., Monografías de Arte y Arqueología, 23, Universidad de Granada.

NoCETE CAlvo, F., 2001: El Tercer Milenio antes de Nuestra Era. Relaciones y contradicciones centro/periferia en al Valle del Guadalquivir. Bellaterra Arqueología, Barcelona.

NoGUERAS CELDRÁN, J.M., 2003: «Arx Asdrubalis. Historia y Arqueología en un espacio privilegiado de Cartagena en la Antigüedad.», Arx Asdrubalis. Arqueología e Historia del Cerro del Molinete en Cartagena (Noguera, ed.): 13-74, Murcia.

OBER. J., 1987: «Early artillery towers: Messenia, Boiotia, Attica, Megarid....»., American Journal of Archaeololgy, 91: 569-604.

Ocejo Herrero, A., 1995: «La situación geográfica de los pelendones según Claudio Ptolomeo.», Poblamiento Celtibérico (Burillo, ed.), III Simposio sobre Celtíberos: 477-493, Zaragoza.

OlCinA DOMÉNeCh, M.; PÉReZ JimÉNEZ, R., 1998: La ciudad ibero-romana de Lucentum (El Tossal de Manises, Alicante). Introducción a la investigación del yacimiento arqueológico y su recuperación como espacio público., Diputación Provincial de Alicante.

Otegui, R., 1986: «Aspectos antropológicos de la casa en la Provincia de Teruel.», Cartillas Turolenses, 4, Teruel

PADRÓ, J.; SANMARTí, E., 1992: «Áreas geográficas de las etnias prerromanas de Cataluña.», Paleoetnología P. Iberica (Almagro y Ruiz Zapatero, eds.), Complutum, 2-3: 185-194.

PAllarÉs Comas, R., 1984: «El sistema defensivo frontal del Castellet de Banyoles, Tivissa, Ribera d'Ebre.», Pyrenae, 19-20: 113-125.

Pallarés Comas, R., 1986: «Dos elements de filiació grega del segle IV a. C. à l'assentament ibèric del Castellet de Banyoles, Tivissa, Ribeira d’Ebre.», Protohistoria Catalana: 281-288.

Pallarés, R.; Gracia, F.; Munilla, G., 1986: «Cataluña: sistemas ibero-griegos de defensa.», Revista de Arqueología, 65: 43-52. 
PALOL, P. DE, 1964: «La muralla céltica del poblado de El Soto de Medinilla.», CNA (Zaragoza 1964), VII: 275-276.

PAlol, P. De; WATtemberg, F., 1974: Carta arqueológica de España. Valladolid., Valladolid.

PARCERO, C., 1995: «Elementos para el estudio de los paisajes castreños del Noroeste peninsular.», TP, 52 (1): 127-144.

PARCERO, C., 2000: «Tres para dos. Las formas de poblamiento en la Edad del Hierro del Noroeste ibérico.», TP, 57 (I): 75-95.

PEÑA, A. DE LA, 1992: «El primer milenio a.C. en el área gallega: Génesis y desarrollo del mundo castreño a la luz de la Arqueología.», Paleoetnología P. Iberica (Almagro y Ruiz Zapatero, eds.), Complutum, 2-3: 373-394.

Peralta LABRAdOR, E., 2000: Los cántabros antes de Roma., BHA, 5, Madrid.

Pereira Dinis, A., 1999: «Povoamento do Baixo Ave no $1^{\circ}$ Milenio A.C.», II CPA (Zamora 1996): 37-48.

PÉREZ MACÍAS, J.A.; BEDIA, M.J., 1995: «Excavaciones de apoyo a la restauración en las murallas de Niebla (Huelva).», AAA 1992, III: 376-383, Sevilla.

PiggotT, S., 1931: «Ladle Hills, an unfinished hill-fort.», Antiquity, 5: 474-485.

PODBORSKY, V., 1970: Mähren under Spätbronzezeit und an der Schwelle der Eisenzeit., Univ. Purkyne, Brno.

PRÓSPER, B.M., 2002: Lenguas y religiones prerromanas del Occidente de la Península Ibérica., Acta Salmanticensia. Estudios Filológicos, 295, Salamanca.

PY, M., 1990: Culture, économie et société protohistoriques dans la région nîmoise., Roma.

QUESADA SANZ, F., 1989: «La utilización del arco y las flechas en la Cultura ibérica.», TP, 48: 161-201.

QueSADA SANZ, F., 1994: «Vías de contacto entre la Magna Grecia e Iberia. La cuestión del mercenariado.», Encuentros Intern. Arqueología de la Magna Grecia, Sicilia y la Península Ibérica (Granada 1994): 75-110.

QUESADA SANZ, F., 1997: El armamento ibérico. Estudio tipológico, geográfico, funcional, social y simbólico de las armas en la Cultura Ibérica (siglos VI a I a.C.)., Monographies Instrumentum, 3 (I y II), Montagnac.

QuESADA SANZ, F., 2001: «En torno al análisis táctico de las fortificaciones ibéricas. Algunos puntos de vista alternativos.», Gladius, XXI:145-154.

QUESADA SANZ, F., 2002: «La evolución de la panoplia, modos de combate y técticas de los iberos.», La Guerra en el Mundo ibérico y celtibérico (Moret y Quesada, eds.), Coll. Casa Velázquez, 78: 35-64.

QuESADA SANZ, F., 2003-a: «De los fosos de Troya a la línea Sigfrido. Las piedras hincadas en el contexto de la historia de las fortificaciones.», Chevaux-de-frise i fortificació en la Primera Edat del Ferro Europea (Alonso et alii, eds.): 69-100, Lleida.

QUESADA SANZ, F., 2003-b: «La guerra en las comunidades ibéricas (c. 237 - c. 195 a.C.): un modelo interpretativo.», en A Morillo, F. Cadiou, D. Hourcade, eds., Defensa y territorio en Hispania: 101-157.

RAFTERY, B., 1991: «Zur Frage Iris-iberischer Beziehungen Während der Eisenzeit.,» Festschrift für Wilhem Schüle zum 60., Geburtstag, Buch am Erlbach.

Ramallo, S.; Ros, M.M.; MAS, J.; Martín, M.; PÉRez, J., 1992: «Carthago Nova.», Dialoghi d'Archeologia (3 ${ }^{a}$ serie), 10: 105-118. 
RENFrEw, C. (ed.), 1983: The Megalithic Monuments of Western Europe., Thames and Hudson, London.

Roldán Gómez, L.; Bendala, M.; Blánquez, J.J.; Martínez Lillo, S., 1998: Carteia., Madrid.

Romeo MARUGÁN, F., 2002: «Las fortificaciones ibéricas del Valle Medio del Ebro y el panorama de los influjos mediterráneos.», La Guerra en el Mundo ibérico y celtibérico (Moret y Quesada, eds.) Coll. Casa Velázquez, 78: 153-188.

Romero Carnicero, F., 1984: La Edad del Hierro en la Serranía Soriana: Los castros., Studia Archaeologica, 75, Valladolid.

Romero CARniCERO, F., 1985: «La Primera Edad del Hierro. El afianzamiento de la sedentarización y la explotación intensiva del Medio.», Historia de Castilla y León, Ámbito, I: 82-92, Valladolid.

Romero CARnicero, F., 1991: Los castros de la Edad del Hierro en el norte de la provincia de Soria., Studia Archaeologica, 80, Valladolid.

Romero CARnicero, F., 1997: «Origen y evolución del grupo castreño de la Serranía Norte Soriana.», en J. Arena y D. Palacios, eds., El Origen del Mundo Celtibérico: 143-164, Guadalajara.

Romero CARniCERO, F., 2003: «Piedras hincadas en el Oriente meseteño.», Chevaux-de-frise $i$ fortificació en la Primera Edat del Ferro Europea (Alonso et alii, eds.): 179-208, Lleida.

Romero Masiá, A., 1976: El hábitat castreño. Asentamientos y Arquitectura de los castros del Noroeste Peninsular., Publicaciones del Colegio Arquitectos de Galicia, Santiago.

RuIz MATA, D., 2001: «Arquitectura y urbanismo en la ciudad protohistórica del Castillo de Doña Blanca (El Puerto de Santa María, Cádiz).», Arquitectura Oriental y Orientalizante en la Península Ibérica (Ruiz Mata y Celestino, eds.): 261-274.

Ruiz Mata, D.; Niveau, A.M.; VAllejo, J.I., 1998: «La ciudad tartésica-turdetana.», en C. Aranegui, ed., Los Iberos, Principes de Occidente. Estructuras de poder en la sociedad ibera: 65-82, Barcelona.

RuIz RodríguEZ, A., 1992: «Etnogénesis de las poblaciones pre-romanas de Andalucía Oriental.», Paleoetnología P. Iberica (Almagro y Ruiz Zapatero, eds.), Complutum, 2-3: 101-108.

Ruiz RodríGuez, A.; Molinos, M.,1989:»Fronteras: un caso del siglo VI aC.», Arqueología Espacial,13:121-135

Ruiz Rodríguez, A.; Molinos, M., 1993: Los Iberos. Análisis arqueológico de un proceso histórico., Crítica Arqueología, Barcelona.

Ruiz Rodríguez, A.; Molinos, M.; Choclán, C., 1991: «Fortificaciones ibéricas en la Alta Andalucía.», Fortificacions - La problemàtica de l'iberic ple (Manresa 1990): 109-126, Manresa.

Ruiz Rodríguez, A.; Molinos, M.; Hornos, F., 1987: «El poblamiento ibérico en el Alto Guadalquivir.», Iberos (Jaén 1985): 239-256.

Ruiz Zapatero, G., 1977: «Fortificaciones en el castro hallstáttico de Valdeavellano (Soria).», Celtiberia, 53: 83-92

RYCKWERT, R., 1985: La idea de la ciudad. Antropología de la forma urbana en el mundo antiguo., Madrid.

SACRISTÁN DE LAMA, J.D., 1995: «Reflexiones en torno al modelo de poblamiento de época celtibérica en la Cuenca Media del Duero.», Poblamiento Celtibérico (Burillo, ed.): 369-372, Zaragoza.

SACRISTÁN DE LAMA, J.D.; SAN Miguel, L.C.; BARRIO, J.; CELIS, J., 1995: «El poblamiento de época celtibérica en la Cuenca Media del Duero.», Poblamiento Celtibérico. III Simposio sobre Celtíberos (Burillo, ed.): 337-367. 
SALINAS DE FRÍAS, M., 1994: «Unidades organizativas indígenas y administración romana en el valle del Duero.», Revisiones de Historia Antigua I. Las estructuras sociales indígenas..... (González y Santos, eds.): 167-179, Vitoria.

SÁnCHEZ-PALENCIA, F.J.; OREJAS, A.; SATRE, I., 2002: «Los castros y la ocupación romana en zonas mineras del NW de la Península Ibérica.», en M.A. De Blas y A. Villa, eds., Los poblados fortificados del Noroeste: 241-259.

SAN Miguel MATE, L.C., 1993: «El poblamiento de la Edad del Hierro al Occidente del valle medio del Duero.», Arqueología Vaccea. Estudios sobre el mundo prerromano..... (Romero, Sanz y Escudero, eds.): 21-65, Valladolid.

SAN Miguel Mate, L.C., 1995: «Civitas y secundarización de la producción: ¿Las dos claves de interpretación del modelo de poblamiento vacceo?, Poblamiento Celtibérico. III Simposio sobre Celtíberos (Burillo, ed.): 373-380, Zaragoza.

San Valero Aparisi, J., 1966: Monte Bernorio, Aguilar del Campoo (Palencia). Campaña de estudio en 1959., AEA, 44, Madrid.

SÁNCHEz MoRENO, E., 1998: «Los vacceos en las fuentes literarias: Historia, geografía, y etnografía de una entidad prerromana a ojos de los clásicos.», H. Ant., XXII: 51-74.

SÁnChez-Palencia, F. J.; Fernández-Posse, M. D.; Fernández Manzano, J.; OrejAs, A., 1996: La Zona Arqueológica de Las Médulas. León. Guía Arqueológica., Salamanca.

SANMARTí, J.; BELARTE, C., 2001: «Urbanización y desarrollo de estructuras estatales en la costa de Cataluña.», Entre Celtas e Iberos (Berrocal-Rangel y Gardes, eds.), BAH, 8: 161-174, Madrid.

SANMARTI, J.; SANTACANA, J., 1991: «Les fortificacions ibèriques de la Catalunya central i costera.», Fortificacions - La problemàtica de l'iberic ple (Manresa 1990): 127-144.

SANTOS Yanguas, N., 1992: «Astures y Cántabros: Estudio Etnológico.», Paleoetnología P. Iberica (Almagro y Ruiz Zapatero, eds.), Complutum, 2-3: 417-430, Madrid.

SANZ Mínguez, C., 2002: «Panoplias prerromanas en el centro y occidente de la Submeseta norte peninsular.», La Guerra en el Mundo ibérico y celtibérico (Moret y Quesada, eds.) Coll. Casa Velázquez, 78: 87-134, Madrid.

Sanz MíngueZ, C.; Velasco, J.; Centeno, I.; Gallardo, M.A.; Del Olmo, J., 2003:»Pintia: nacimiento y desarrollo de un oppidum vacceo-romano.», Pintia. Un oppidum ..... (Sanz y Velasco, eds.): 45-65, Valladolid

SASTRE, I., 2000: Las formaciones sociales rurales de la Asturia romana., Ediciones Clásicas, Madrid.

SASTRE, I., 2002: «Forms of social inequality in the Castro Culture of north-west Iberia.», European Journal of Archaeology, 5 (2): 213-248.

SAVORY, H. 1975: «Algunas influencias del Mediterráneo Occidental en la temprana Edad del Hierro de Gales.», CPAC, 2: 81-86.

SchatTnER, TH. G., 2003: «Die lusitanisch-galläkischen Kriegerstatuen.», Die lusitanischgalläkischen Kriegerstatuen, MDAI (M), 44: 1-5.

SchubART, H., 2000: «El yacimiento fenicio y las fortificaciones en la cima de Toscanos.», en F.J. González-Prats, eds., Fenicios y Territorio: 263-294, Alicante.

Schubart, H.; ArteagA, O.; Pingel, V., 1986: «Fuente Álamo. Vorbericht über die Grabung 1985 in der bronzezeitlichen Höhensiedlung.», MDAI (M), XXVII: 27-63.

SHENNAN, S., 1989: «Introduction: archaeological approaches to cultural identity.», Archaeological Approaches to Cultural Identites (Shennan, ed.), One World Archaeology, 10: 1-32, London. 
Silva, A. Coelho Ferreira DA, 1986: A Cultura Castreja no Noroeste de Portugal., Museo Arqueológico da Citanía de Sanfins., Paços da Ferreira.

Silva, A. Coelho Ferreira DA, 2003: «Expressôes guerreiras da sociedade castreja.», Die lusitanisch-galläkischen Kriegerstatuen, MDAI (M), 44: 41-50.

SoAres, A. Monges, 1986: «O povoado do Passo Alto. Escavaçôes de 1984.», Arquivo de Beja, III-2 ${ }^{\mathrm{a}}$ serie: 89-99.

SoARes, A. Monges, 2003: «O Passo Alto. Uma fortificaçâo única do Bronze Final do Sudoeste.», Revista Portuguesa de Arqueología, 6.2: 293-312.

TARACEna AguirRe , B., 1941: Carta Arqueológica de España. Soria., CSIC, Madrid.

Tilley, C., 1994: A Phenomenology of Landscape. Places, Paths, and Monuments., Berg ed., Oxford.

TORRES OrTIZ, M., 2002: Tartessos., BAH, 14, Madrid.

TREZINY, H., 1986: «Les techniques grecques des fortifications et leur diffusion à la péripherie du Monde Grec d'Occident.», La fortification dans l' Histoire du Monde Grec (Leriche y Treziny, eds.): 185-200.

TReZINY, H., 1993: «Le Grande Grèce et Sicile.», A la decouverte des forteresses grecques, Les Dossiers d'Archeologie, 179: 42-49.

TRIGGER, B. G., 1990: «Monumental architecture: a thermodynamic explanation of symbolic behaviour.», World Archaeology, 22 (2): 119-131.

UrquiJo Álvarez, C.; URBINA, D., 2000: El proyecto arqueológico Plaza de Moros., Asociación Comarcal D. Quijote de la Mancha, Madrid.

VÉLEZ Rivas, J.; PÉReZ AviLÉs, J.J., 1987: «El yacimiento protohistórico del Cerro de Las Cabezas (Valdepeñas, Ciudad Real).», Oretum, III: 167-196.

VILla VALDÉs, A., 2001: «Descripción de estructuras constructivas en el castro del Chao Samartín.», Boletín Museo Provicial de Lugo, IX: 367-419.

VILla VALDÉs, A., 2002: «Periodización y registro arqueológico en los castros del cccidente de Asturias.», Los poblados fortificados del NW (De Blas y Villa, eds.): 159-188, Navia.

Wells, P.S., 1989: Farms, Villages, and Cities. Commerce and Urban Origins in Late Prehistoric Europe., Cornell U.P, Ithaca and London.

Xusto, M., 2000: «O contexto territorial e urbanismo dos castros.», Historia Arte Galega, I-fas.8: 129-144, Vigo.

ZAFrA, N.; Hornos, F.; CASTRO, M., 1999: «Una macro-aldea en el origen del modo de vida campesino: Marroquíes Bajo (Jaén). C. 2500 - 2000 cal. ANE.», TP, 56 (1): 77-102.

ZAFRA, N.; CASTRO, M.; HORNOS, F., 2003: «Sucesión y simultaneidad en un gran asentamiento: la Cronología de la macro-aldea de Marroquíes Bajos, Jaén. C. 2500-2000 cal. ANE.», TP: 60 (2): 79-90. 